\title{
Testing of and Model Development for Double-Walled Thermal Tubular
}

\section{'Topical Report}

\section{R. M. Satchwell \\ L. A. Johnson, Jr.}

August 1992

Work Performed Under Contract No.: DE-FC21-86MC11076

\author{
For \\ U.S. Department of Energy \\ Office of Fossil Energy \\ Morgantown Energy Technology Center \\ Morgantown, West Virginia
}

By

Western Research Institute

Laramie, Wyoming 


\section{DISCLAIMER}

This report was prepared as an account of work sponsored by an agency of the United States Government. Neither the United States Government nor any agency thereof, nor any of their employees, makes any warranty, express or implied, or assumes any legal liability or responsibility for the accuracy, completeness, or usefulness of any information, apparatus, product, or process disclosed, or represents that its use would not infringe privately owned rights. Reference herein to any specific commercial product, process, or service by trade name, trademark, manufacturer, or otherwise does not necessarily constitute or imply its endorsement, recommendation, or favoring by the United States Government or any agency thereof. The views and opinions of authors expressed herein do not necessarily state or reflect those of the United States Government or any agency thereof.

This report has been reproduced directly from the best available copy.

Available to DOE and DOE contractors from the Office of Scientific and Technical Information, P.O. Box 62, Oak Ridge, TN 37831; prices available at (615) $576-8401$.

Available to the public from the National Technical Information Service, U.S. Department of Commerce, 5285 Port Royal Rd., Springfield, VA 22161; phone orders accepted at (703) 487-4650. 


\title{
Testing of and Model Development for Double-Walled Thermal Tubular
}

\author{
Topical Report
}

R. M. Satchwell

L. A. Johnson, Jr.

Work Performed Under Contract No.: DE-FC21-86MC11076

For

U.S. Department of Energy

Office of Fossil Energy

Morgantown Energy Technology Center

P.O. Box 880

Morgantown, West Virginia 26507-0880

By

Western Research Institute

P.O. Box 3395

Laramie, Wyoming 82071-3395

August 1992 
LIST OF FIGURES AND TABLES.................................................... iii

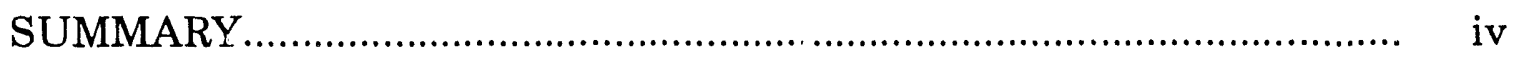

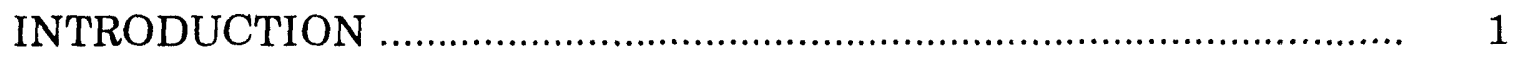

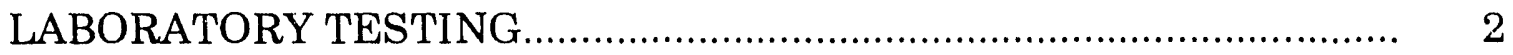

Flow Loop Description.................................................................. 2

Test Sections................................................................................. 6

Experimental Procedure................................................................ 6

Experimental Results.................................................................. 10

NUMERICAL MODEL DESCRIPTION............................................... 14

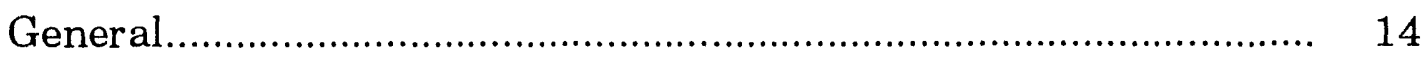

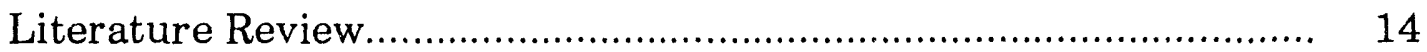

Model Description......................................................................... 17

Model Sensitivity Analysis........................................................ $\quad 20$

Model Verification.................................................................... 26

CONCLUSIONS AND RECOMMENDATIONS..................................... 28

ACKNOWLEDGEMENTS ................................................................. 31

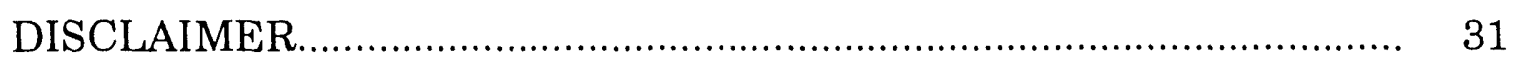

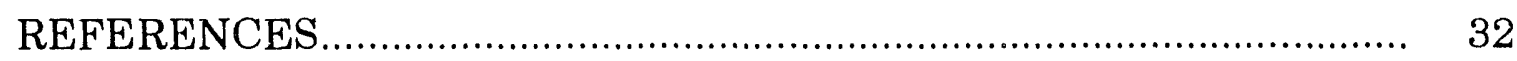

APPENDIX A. Experimental Data...................................................... 34

APPENDIX B. Computer Code........................................................ 46

APPENDIX C. Materials Description....................................................... $\quad 70$ 


\section{LIST OF FIGURES AND TABLES}

Figure

Page

1. Experimental Apparatus............................................................

2. Data Acquisition Schematic.........................................................

3. Generalized Double-Walled Pipe Cross-Section................................ 6

4. Pipe Body Temperature History with Insulation............................ 8

5. Pipe Body Temperature History without Insulation...................... 8

6. Pipe Coupling Temperature History with Insulation...................... 9

7. Pipe Coupling Temperature History without Insulation................. 9

8. Case Studies of Heat Losses.......................................................... 25

9. Case Studies of Steam Quality .................................................... 25

10. Numerical Model Comparisons........................................................ 27

\section{$\underline{\text { Table }}$}

1. Experimental Test Conditions....................................................... 11

2. Experimental Heat Loss Summary ................................................ 12

3. Single Tubing String Sensitivity Study of Numerical Model Parameters

4. Double-Walled Tubing String Sensitivity Study of Numerical Model Parameters. 


\section{SUMMARY}

Insulated tubular products have become essential for use in steam injection projects. In a steam injection project, steam is created at the surface by either steam boilers or generators. During this process, steam travels from a boiler through surface lines to the wellhead, down the wellbore to the sandface, and into the reservoir. For some projects to be an economic success, cost must be reduced and oil recoveries must be increased by reducing heat losses in the wellbore. With reduced heats losses, steam generation costs are lowered and higher quality steam can be injected into the formation.

To address this need, work under this project consisted of: the design and construction of a thermal flow loop, testing a double-walled tubular product that was manufactured by Inter-Mountain Pipe Company, and the development and verification of a thermal hydraulic numerical simulator for steam injection. Four different experimental configurations of the doublewalled pipe were tested. These configurations included: (1) bare pipe case, (2) bare pipe: ase with an applied annular vacuum, (3) insulated annular pipe case, and (4) insulated annular pipe case with an applied annular vacuum. Both the pipe body and coupling were tested with each configuration.

The results of the experimental tests showed that the Inter-Mountain Pipe Company double-walled pipe body achieved a 98 percent reduction in heat loss when insulation was applied to the annular portion of the pipe. The application of insulation to the annular portion of the coupling reduced the heat losses by only 6 percent. In tests that specified the use of a vacuum in the annular portion of the pipe, leaks were detected and the vacuum could not be held. 
From this work a new model for simulating the thermal hydraulics of saturated steam or hot water was developed. This model is capable of simulating the heat losses in surface lines from the boiler and through the wellbore to the reservoir sandface. This mudel extends the prediction of heat loss by allowing for a variety of surface pipe configurations and/or wellbore configurations to be simulated. The comparison of this new model to previously published models was performed. The new model can predict the field data over a larger range of operating parameters with better accuracy than any of the previously published models. Using this model, temperature, pressure, and steam quality at the reservoir sandface can be predicted with a high degree of accuracy and reliability. The information gained from these predictions can be used to design better well completion and provide better accuracy of steam flood performance. 


\section{INTRODUCTION}

In light oil reservoirs, conventional oil recovery may extract up to 35 percent of the oil in the reservoir. In heavy oil reservoirs, a considerably larger fraction is left in-place. Thermal oil recovery techniques have demonstrated that a large amount of this unproduced heavy oil can be recovered. The major thermal recovery techniques in use are steam injection and in situ combustion.

Steam injection accounts for over 75 percent of the oil recovered using enhanced oil recovery (EOR) techniques. Efficient methods of transferring steam from the surface to the oil reservoir can reduce the cost of enhanced oil recovery. This can be achieved by reducing the heat losses in the injection string. Use of insulated tubulars can reduce the thermal losses and make the economics of steam EOR projects even more favorable.

The problem of controlling heat losses is one of considerable complexity. An insulated tubular design should produce a completion that will provide for minimum heat loss in the well. The selection of materials that will withstand the temperature extremes is also of major importance. The key to proper thermal recovery completions thus lies in an accurate knowledge of the temperatures and stresses involved. In addition, severe operating conditions that are imposed on completed injection wells should be considered. Temperatures must be kept at an acceptable level to avoid damage to or even failure of the casing.

To evaluate the feasibility of a hot fluid injection project, a good estimate of the heat carried by the injection fluid is extremely important. Knowing the temperature, pressure, and quality of the fluid at the formation is necessary to calculate heat content. However, at the present time, a physical method for measuring these bottom hole parameters is not available. A computer model must be used to estimate these parameters. 
Inter-Mountain Pipe Company has developed a double-walled tubular which has the potential for being applicable in steam injection. However, laboratory verifications of the performance data were needed. These data include heat losses, temperature profiles, and other operating conditions. Western Research Institute (WRI) assembled a flow loop to develop a performance data base. The data are described in this report.

The primary objectives of this work were to: (1) evaluate Inter-Mountain Pipe's double-wall tubular for steam injection, and (2) develop a computer model to simulate the transient effect of steam injection under field conditions. These objectives were accomplished by building an instrumentated flow loop to test Inter-Mountain Pipe's product and developing a computer model to handle single- and double-walled tubing under a variety of conditions. The computer model was based on the Jensen and Sharma (1989) model, and includes the modeling efforts of Ramey (1962) and Satter (1963). Jensen and Sharma's model was modified to include boundary conditions not considered in the original work. The model developed includes several new theoretical and mathematical correlations, and an iteration scheme for pressure convergence. This makes it more comprehensive and versatile in solving the heat transfer problems associated with steam injection.

\section{LABORATORY TESTING}

\section{Flow Loop Description}

A steam flow loop was constructed at WRI's North Site facilities. The flow loop was designed such that heat loss in both the horizontal and vertical sections could be determined. The flow loop is shown schematically in Figure 1. The major components of the flow loop were: (1) a steam boiler, (2) a vertical flow section, (3) a horizontal flow section, and (4) a water recovery system. The tubular products used to build this flow loop were designed and fabricated by the Inter-Mountain Pipe Company. 


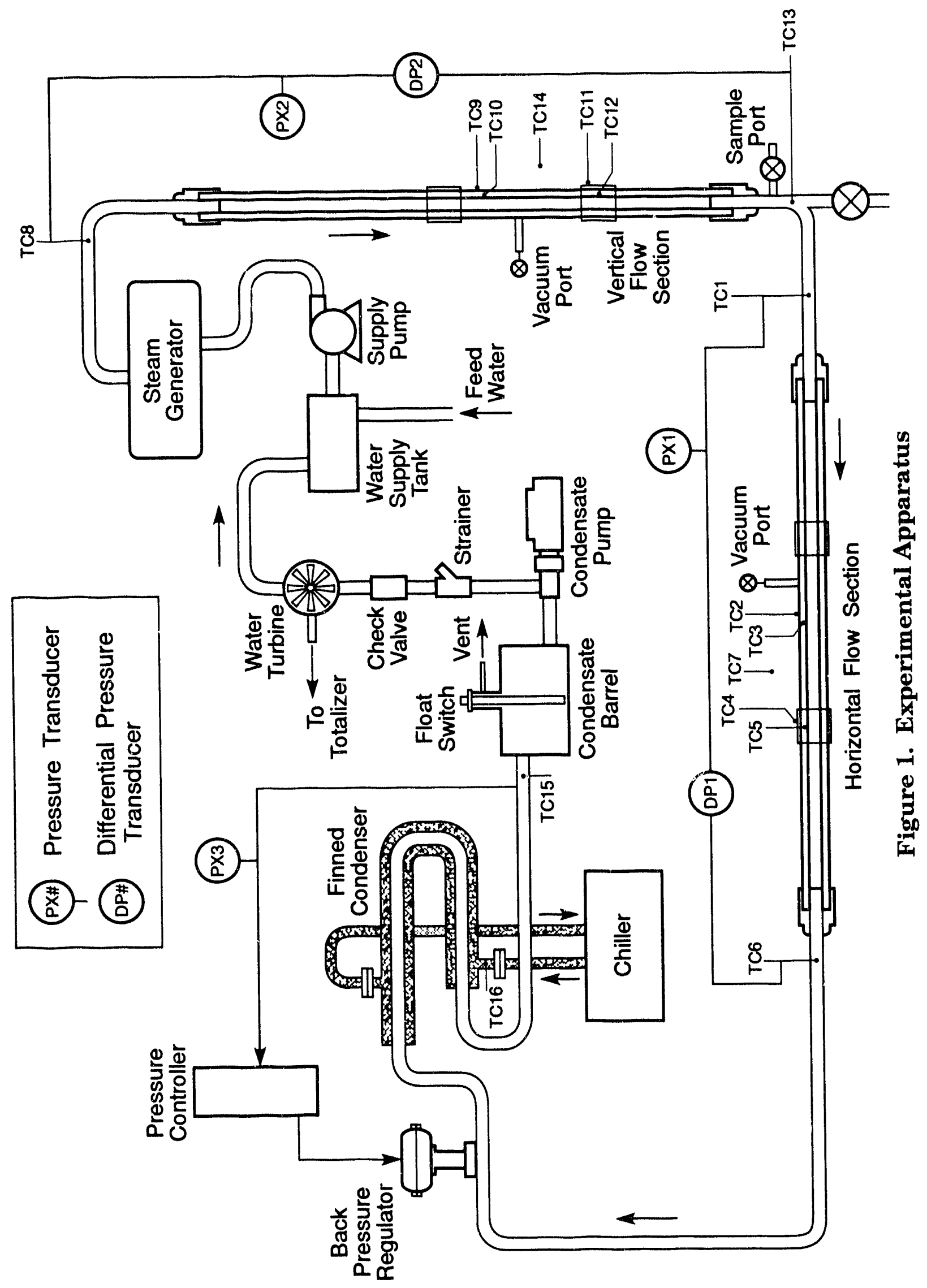


The setup was designed as a closed flow loop system. Pressures and cross-sectional temperatures were monitored in each of the individual test sections, and recorded by the data acquisition system shown in Figure 2.

The setup was such that the steam generated from the boiler first flowed through the vertical test section and then through the horizontal test section, and into a water recovery system. Between the vertical and horizontal test sections, a sampling port was installed to drain and collect condensate. The electrical conductivities of the condensate and feed water were used to determine the average steam quality that existed between the two test sections.

The water recovery system incorporated a back-pressure regulator, a counter-current heat exchanger, a forced-air water chiller, and a condensate receiver with a float switch and a pump. The system provided a method for condensing the steam to water which was then pumped back to the boiler make-up water supply tank. The pressure controller and back-pressure regulator were incorporated in the system for three reasons. These reasons were: (1) to maintain a constant, overall system pressure, (2) to ensure that the steam was fully condensed into liquid after passing through the heat exchanger, and (3) to ensure that the condensate receiver was not pressurized.

The flow rate, temperature, and pressure of the water recovery system were continuously monitored to: (1) ensure complete condensation of the steam into water, (2) determine cold-water-equivalent flow rate, and (3) provide protection to the individual components that were sensitive to pressure and temperature. 


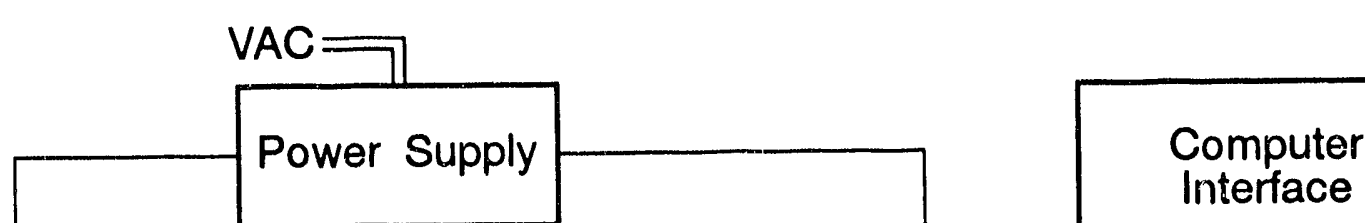

Differential Pressure
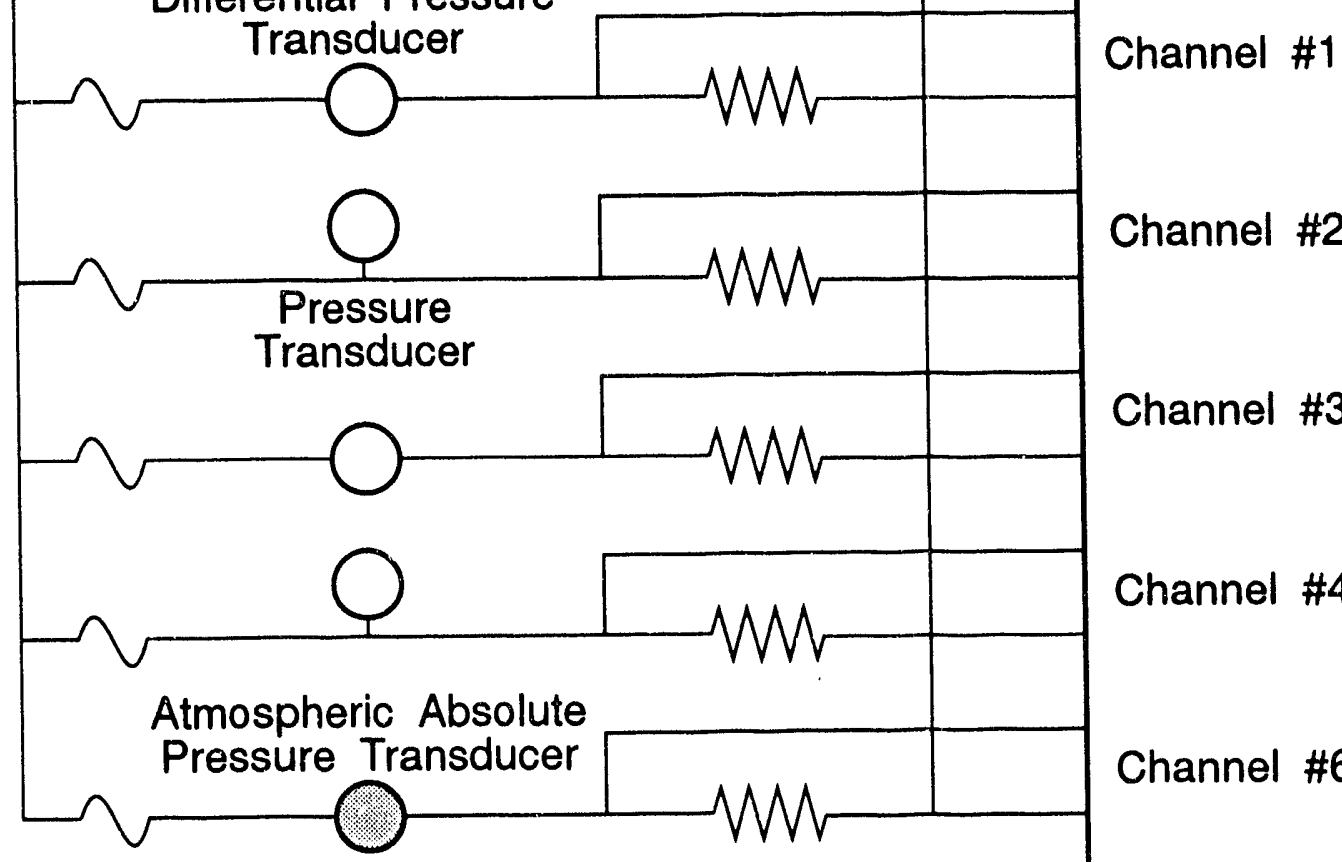

Channel \#3

Channel \#4

Channel \#6
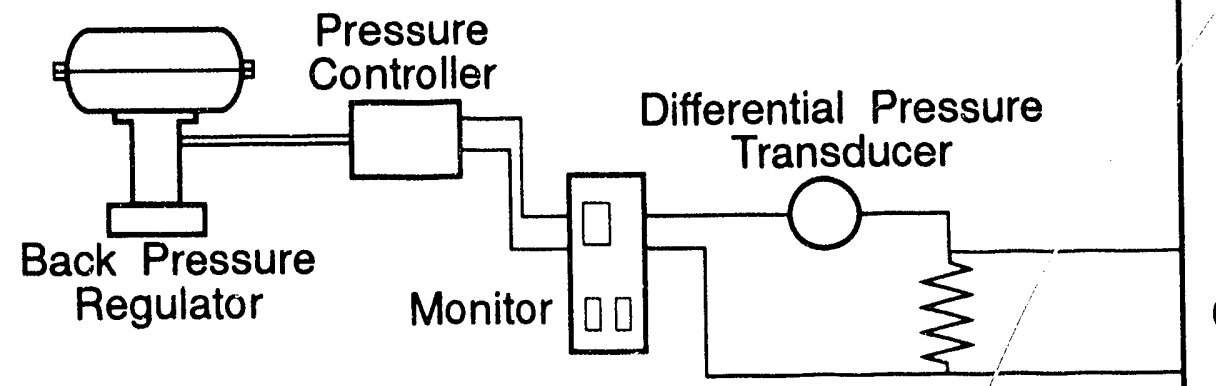

Channel \#7
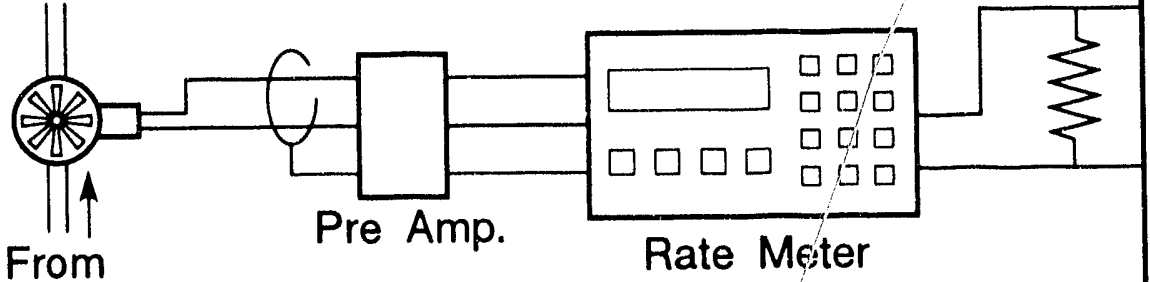

Channel \#5

From

Flow

Loop

Figure 2. Data Acquisition Schematic 


\section{Test Sections}

Each test section (vertical and horizonial) was composed of an entrance, a test, and an exit subsection. Each of the sections was fabricated from InterMountain Pipe's double-walled tubular product. The entrance subsection was about 153 inches long, with the test subsection being approximateiy 36 inches long. The length of the exit subsection was about 53 inches long. The subsection lengths were selected based on boundary layer theory, to establish stabilized flow conditions in each test section. The dimensions and configuration of the double-walled tubing body and associated coupling can nó íe shown because the design is proprietary. However, a generalized schematic of the pipe cross-section is shown in Figure 3.
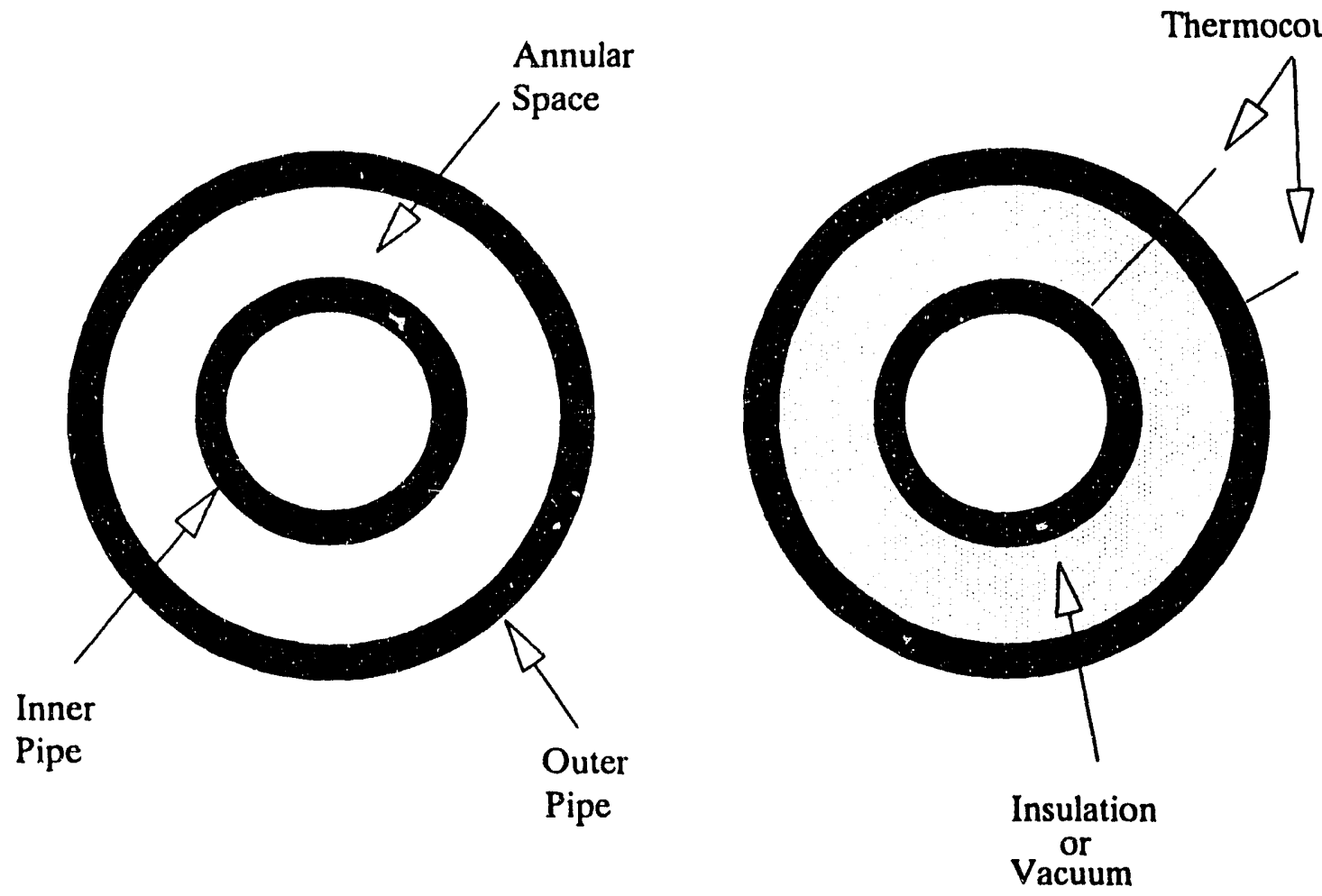

Figure 3. Generalized Double-Walled Pipe Cross-Section 
Inlet and exit fluid temperatures to the horizontal and vertical test sections were monitored using thermocouples TC1 and TC6, and TC8 and TC13, respectively. All thermocouple locations are shown in Figure 1. Thermocouples TC2 and TC3 in the horizontal test section and TC9 and TC10 in the vertical test section were positioned to measure the outside temperatures of the inner and outer tubing bodies, respectively of the doublewalled tubes. The same configuration was implemented for measurements of the coupling temperatures, using thermocouples TC4 and TC5, and TC11 and TC12 in the horizontal and vertical test sections, respectively. Ambient temperatures were monitored for both the horizontal and vertical sections using thermocouples TC7 and TC14, respectively. Both absolute and differential pressures were monitored in the horizontal and vertical sections.

\section{Experimental Procedure}

Four different experimental configurations of the double-walled tubing were tested. These were: (1) no annular insulation, no vacuum; (2) no annular insulation, with vacuum; (3) annular insulation, no vacuum; and (4) annular insulation, with vacuum.

Each of the configurations was tested at steady-state flow conditions for a duration of 4 to 5 hours. Each experiment was initiated by stabilizing the boiler at $273^{\circ} \mathrm{F}\left(134^{\circ} \mathrm{C}\right)$. After stabilization, the valve between the boiler and flow loop was opened, allowing the steam to flow.

Typical experimental temperature profiles for the pipe body and pipe coupling, with and without insulation, are displayed in Figures 4, 5, 6, and 7, respectively. In all cases, steady-state stabilized temperature profiles were achieved in approximately one hour. The shape of the temperature histories were similar at all experimental conditions. In the case of the pipe bodies, Figures 4 and 5 , the difference in temperature and the temperatures of the inner and outer walls were reduced by installing insulation in the annular portion of the pipe. As with the pipe couplings, Figures 6 and 7, little change in the temperatures was observed. 


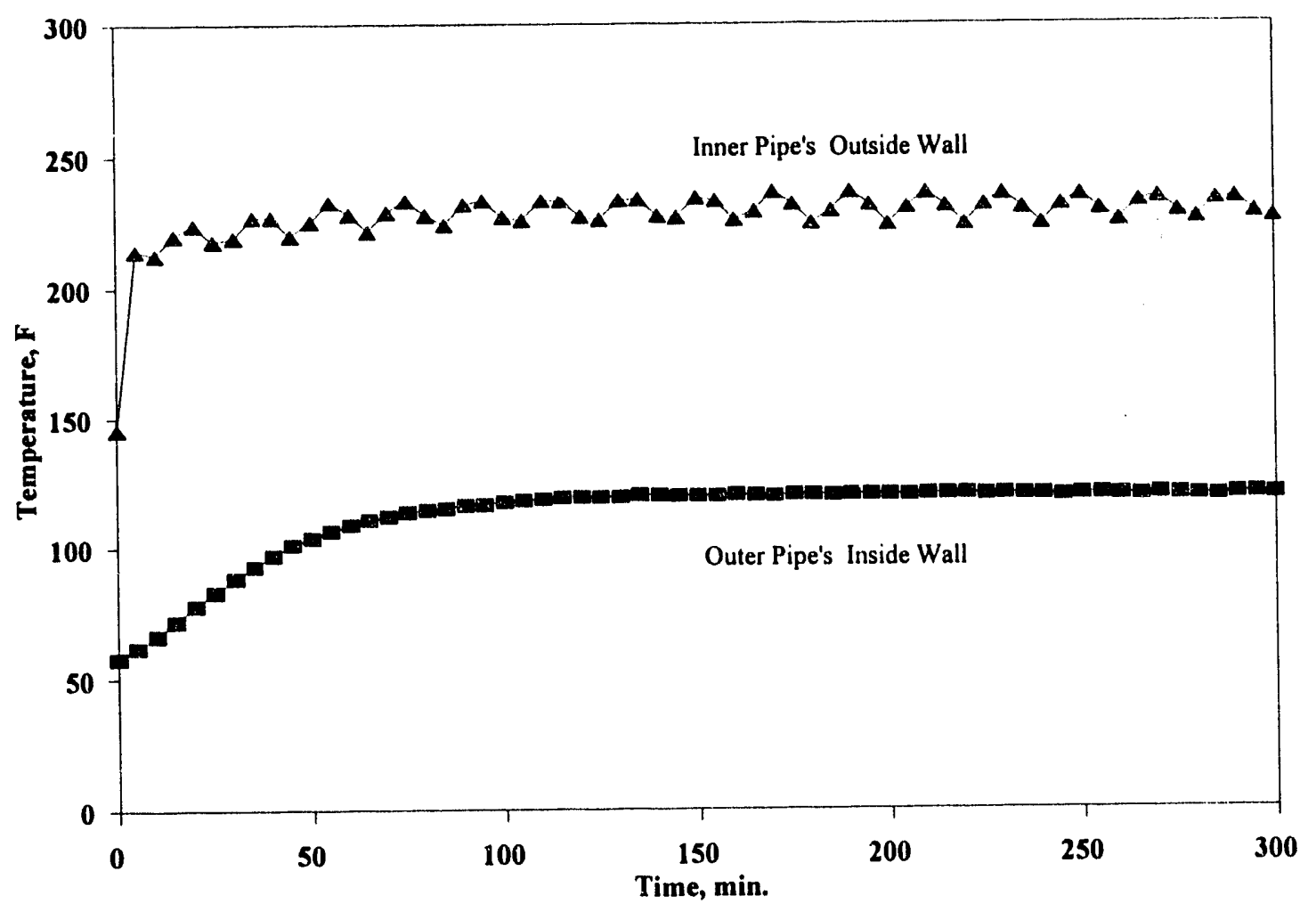

Figure 4. Pipe Body Temperature History with Insulation

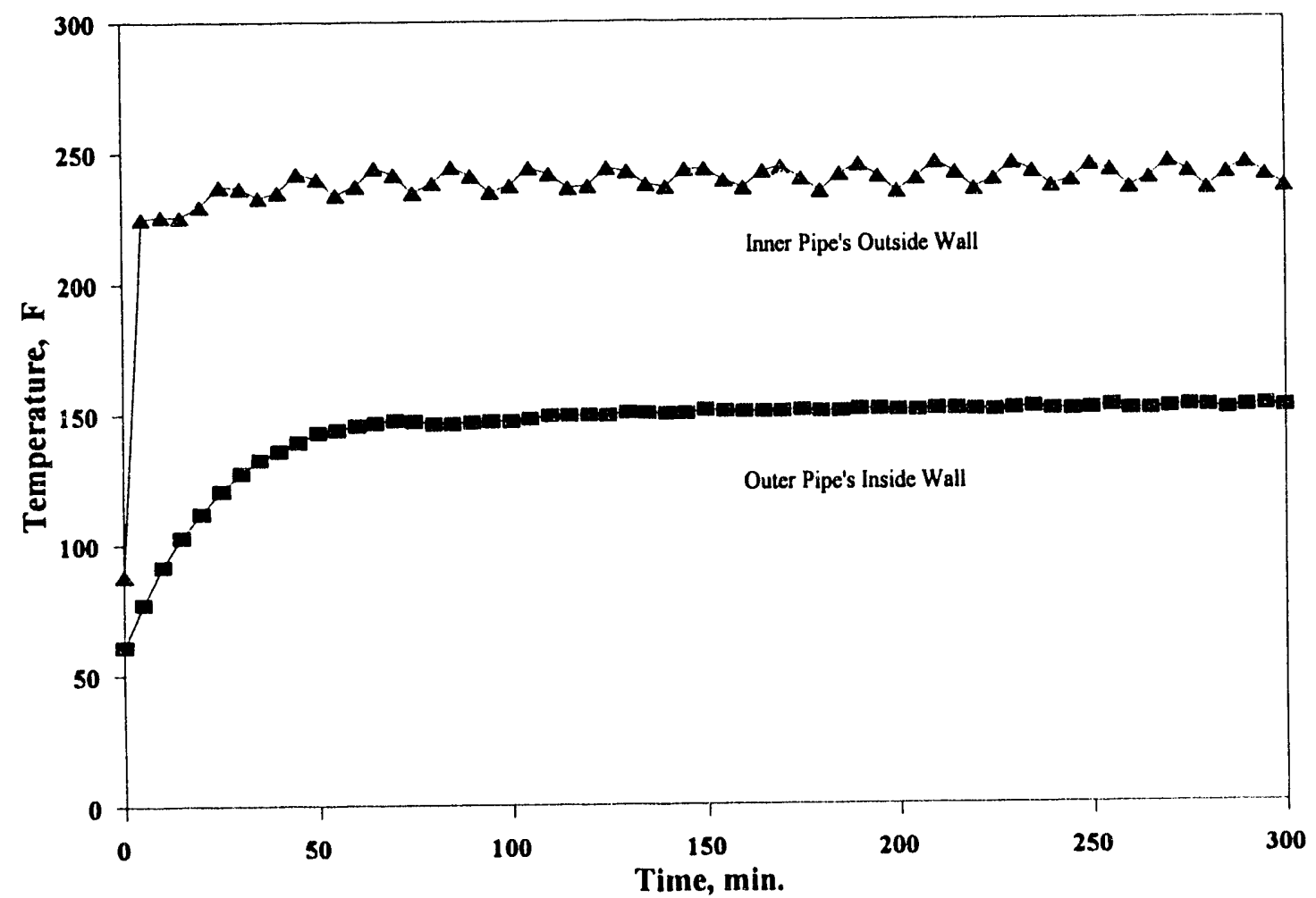

Figure 5. Pipe Body Temperature History without Insulation 


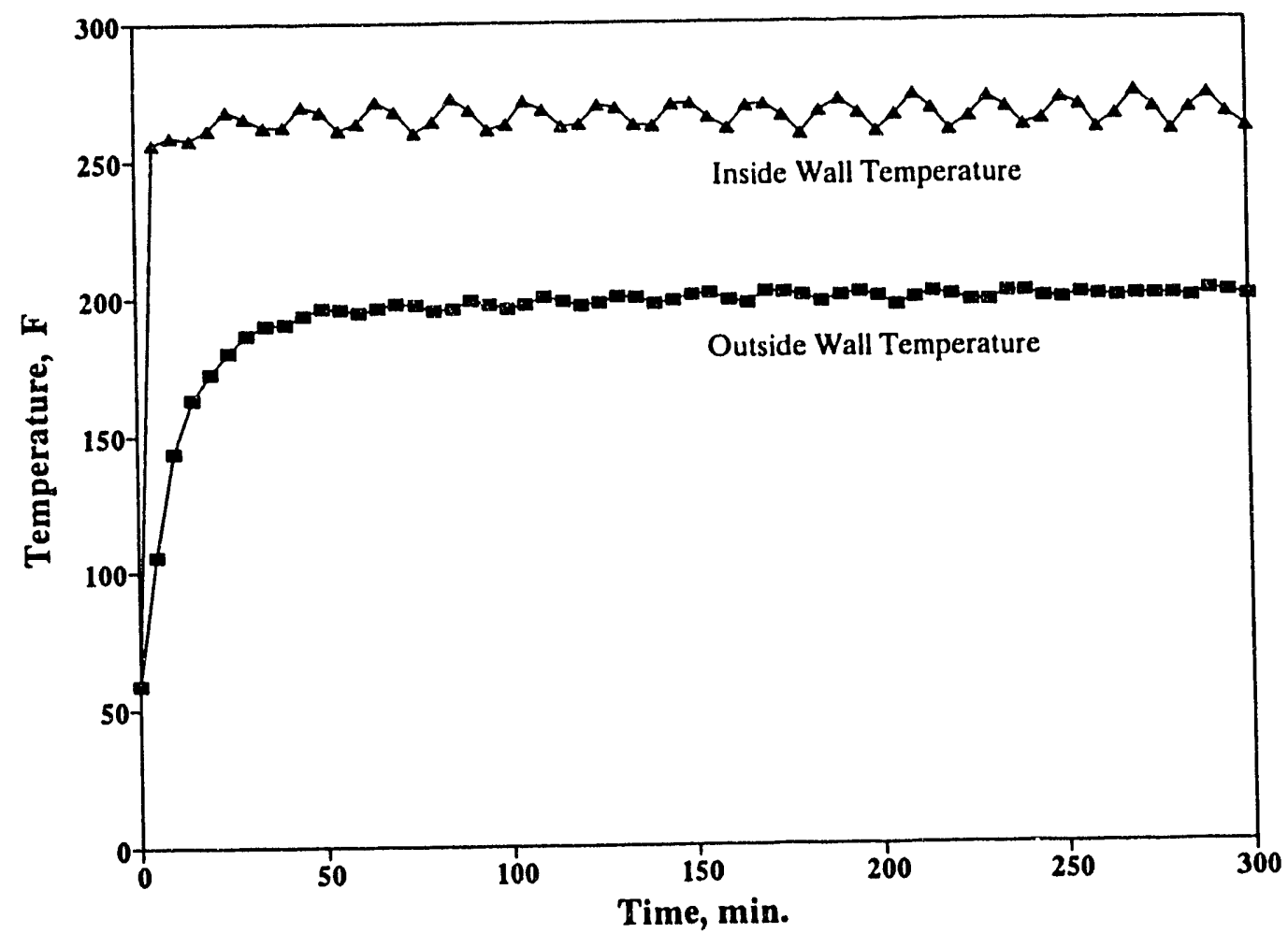

Figure 6. Pipe Coupling Temperature History with Insulation

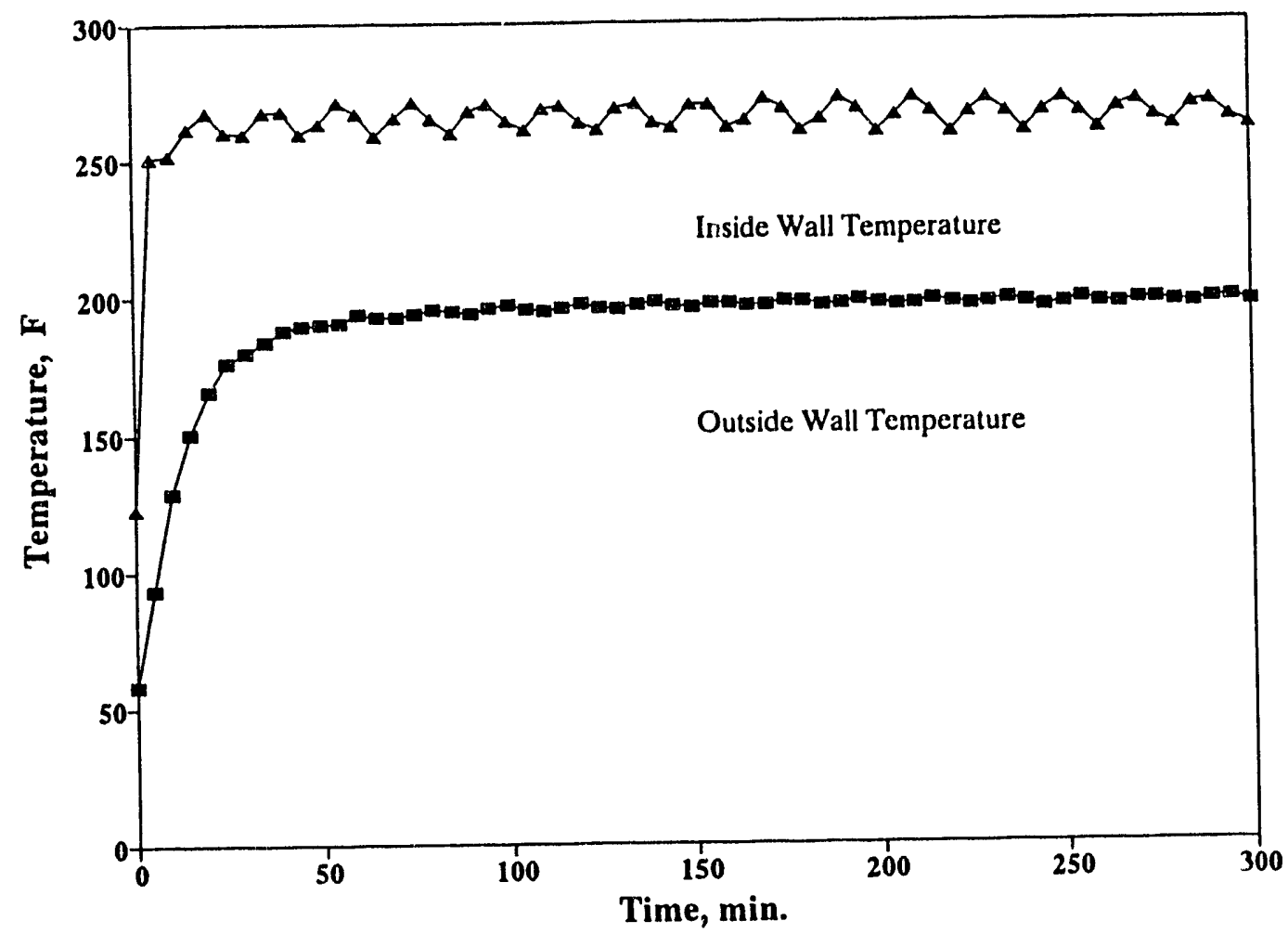

Figure 7. Pipe Coupling Temperature History without Insulation 
Flow was regulated manually with the use of a back-pressure regulator valve. The temperature and pressure were monitored at the inlet of the water recovery system. If the temperature at the inlet of the condensate barrel exceeded $180^{\circ} \mathrm{F}\left(82^{\circ} \mathrm{C}\right)$, then the regulator valve was further closed in order to reduce the temperature, which allowed the steam to completely condense. The condensate pump was controlled by a float switch. A turbine meter was employed to monitor the rate and the total volume of condensate pumped during each test period.

For testing configurations 2 and 4, a vacuum was applied to the annulus of the test sections. The testing procedure originally developed was to implement a pressure switch such that the vacuum pump would operate intermittently and maintain a pressure less than 0.1 torr in the annulus. However, the seals provided on the double-wall pipe could not hold a sufficient vacuum; thus, the vacuum pump ran continuously during the duration of all tests that used configurations 2 and 4 .

A condensate sample from the flow loop and a feedwater sample from the boiler were taken approximately 30 minutes before each test was completed. The samples were allowed to cool, and electrical conductivities were measured and recorded. The data were used to compute the steam quality based on the water conductivity.

\section{Experimental Results}

A summary of the experimental test conditions is given in Table 1. The rate of heat injection through the flow loop during each test period ranged from 226,892 to 256,515 Btu per hour. The steam quality varied from 93.9 to 97.3 percent. The total cold-water-equivalent flow rate varied from 725 to 819 gallons per day. After the steady-state temperature profiles were achieved, the differential pressures were constant during the physical simulations. 
Table 1. Experimental Test Conditions

\begin{tabular}{lccc} 
Test No. & Steam Quality, \% & $\begin{array}{c}\text { Flow Rate, } \\
\text { gal/day }\end{array}$ & $\begin{array}{c}\text { Total Heat Injected, } \\
\text { Btu/hr }\end{array}$ \\
\hline & & & \\
2 & 94.1 & 819 & 251,330 \\
3 & 93.9 & 790 & 242,061 \\
4 & 97.3 & 816 & 256,515 \\
5 & 96.7 & 725 & 226,892 \\
& 95.2 & 807 & 249,723 \\
\hline
\end{tabular}

Heat losses were computed with the following assumptions: (1) steadystate conditions existed in the test sections, (2) one-dimensional heat transfer in the radial direction, (3) negligible pipe wall thermal resistance, (4) convective heat transfer coefficient was constant, and (5) emissivity of steel was constant.

Based on these assumptions, the heat loss for each of the test sections and each test configuration was calculated using the temperature data given in Appendix A. A summary of the experimental results for the heat losses for several combinations of independent variables tested including the test section (either horizontal or vertical), the location (either pipe body or coupling), the insulation (installed or not installed), and the vacuum (with or without) is presented in Table 2.

Statistical analysis of the data was performed with respect to heat loss using coded data that represented the non-numerical data in matrix form. A matrix was developed using the independent variables (test number, test section, location, insulation, and vacuum) with respect to the dependent variable (heat loss). This matrix was developed with each independent variable having a normal distribution. For example, the coding of the insulation data was performed by assigning either $a+1$ or a -1 , signifying that insulation was installed or not installed, respectively. After this coding was performed, both Pearson's product moment correlation coefficients 
(Hines 1980) and Spearman's rank order correlation coefficients (Ullman 1972) were obtained from the analysis. Both methods were used to determine if any correlations existed between the heat loss and the other independent variables. No significant correlation was found between the test numbers and the test sections. This indicated that the physical simulations and testing procedures from test to test were performed in an unbiased manner. The analysis also showed that insulation and location terms were the only significant variables. There was no significant difference between the horizontal and vertical test sections.

Table 2. Experimental Heat Loss Summary

Test

Test No.
Heat Loss

Location Insulation Vacuum Measured, ${ }^{\text {a }} \mathrm{Btu} / \mathrm{hr}$

\begin{tabular}{lccccr}
\hline & & & & \\
1 & Horizontal & Body & yes & no & 65 \\
2 & Horizontal & Body & yes & yes & 65 b \\
3 & Horizontal & Body & no & yes & 5035 \\
4 & Horizontal & Body & no & no & 4530 \\
5 & Horizontal & Body & yes & no & 144 \\
1 & Horizontal & Coupling & no & no & 4044 \\
2 & Horizontal & Coupling & no & yes & 4165 \\
3 & Horizontal & Coupling & no & yes & 4708 \\
4 & Horizontal & Coupling & no & no & 4226 \\
5 & Horizontal & Coupling & yes & no & 3384 \\
1 & Vertical & Body & no & no & 4875 \\
2 & Vertical & Body & no & yes & 4925 \\
3 & Vertical & Body & yes & yes & 144 \\
4 & Vertical & Body & yes & no & 145 \\
5 & Vertical & Body & yes & no & 144 \\
1 & Vertical & Coupling & no & no & 3621 \\
2 & Vertical & Coupling & no & yes & 3621 \\
3 & Vertical & Coupling & no & yes & 4226 \\
4 & Vertical & Coupling & no & no & 2573 \\
5 & Vertical & Coupling & no & no & 3412 \\
& & & & \\
\hline
\end{tabular}

a Measured in 3-feet pipe body or 6.75-inch coupling

b Possible steam leak to annulus during test 
All vacuum tests were intended to be performed at an absolute pressure of less than 0.1 torr. Perry's Chemical Engineering Handbook (Perry and Green 1984) states that pressure dependence of the thermal conductivities of gases is negligible between pressures of 1 torr to 10 atmospheres. Below pressures of 0.1 torr, the thermal conductivities of gases are almost proportional to absolute pressure and could be decreased by applying a higher vacuum. The insignificance of the vacuum variable can be attributed to the fact that a reasonable vacuum was never obtained in the annular space. Since, heat losses were not reduced and an increase in annulus pressure was observed, it appears that an adequate vacuum could not be maintained even though the vacuum pump ran continuously.

The results of the tests on the 3 -feet test sections indicated that the insulated pipe body had an average heat loss rate of about 105 Btu per hour; whereas the uninsulated pipe body had an average heat loss rate of 4,703 Btu per hour, a 98 percent reduction in the overall heat loss. The 6 -inch long insulated pipe coupling had a heat loss rate of 3,384 Btu per hour; whereas the uninsulated coupling averaged a heat loss rate of 3,575 Btu per hour, only a 6 percent reduction in the heat loss rate. This relatively minor reduction in the heat loss rate in the insulated coupling is a direct consequence of the major heat loss path through the metal to metal contact of the inner tube support steel ring located in the coupling.

If a new coupling design could incorporate an insulator support ring instead of the metal support ring, and/or a smaller cross-section area, then the heat losses could be reduced dramatically. Furthermore, if a positive seal system was designed which would support a vacuum of less than 0.1 torr, the heat losses could be reduced further. 


\section{NUMERICAL MODEL DESCRIPTION}

\section{General}

The thermal hydraulics model presented in this paper calculates the heat losses in surface piping and the wellbore during steam injection. The model has been compared with other models and validated with field data. This model can be used as a tool to assist in designing steam injection systems and steam flood projects. The problem of estimating heat losses is of considerable complexity. Some of the phenomena involved in the modeling effort include: non-isothermal fluid flow, two-phase fluid flow, and transient heat losses.

This modeling effort was divided into two parts: (1) the analysis of the heat transfer process which leads to the predication of the overall heat transfer coefficient and heat loss, and (2) the analysis of pressure loss predictions. In the case of surface lines or wellbores, heat is transferred from or to a fluid by means of a differential temperature. All three heat transfer modes, conduction, convection, and radiation, can contribute to the heat transfer process in wells.

\section{Literature Review}

A number of investigators have presented models for wellbore heat loss during steam injection projects. The following discusses some of the more important contributions in the literature. These contributions are given in order of increased accuracy of prediction and sophistication.

One of the first studies of wellbore heat losses was by Moss and White (1959). Their method divided the well into a finite number of point sources or sinks (production or injection). Temperature was calculated as a function of time and depth using an exponential integral approach. Their model also included an iterative procedure to match the heat gained or lost to the surrounding formation. Errors inherent in their modeling effort were: (1) 
the neglecting of radiation in the annulus, (2) neglecting the changes in fluid properties, (3) the use of the line source solution procedure, and (4) the assumption of a source of constant strength with time.

Ramey (1962) presented an approximate solution to the wellbore heat transmission problem for the injection of hot or cold fluids. His solution estimated the temperature of fluids, tubing, and casing as a function of depth and time. Ramey's solution assumed that heat transfer in the wellbore was steady state, while heat transfer to the earth was unsteady radial convection. Other assumptions in his model include: (1) formation and fluid properties were independent of depth and temperature, (2) radiation heat losses, frictional losses, and kinetic losses were negligible, and (3) the overall heat transfer coefficient was independent of depth.

Satter (1963) extended Ramey's model for use with saturated steam. In his solution method, fluid temperature and wellbore heat transfer coefficient were used in semi-analytical correlations to obtain steam quality as a function of depth and time. Satter improved Ramey's model by providing correlations for heat transfer coefficient and fluid properties as functions of depth. However, Satter's solution method was similar to Ramey's, in that changes in pressure with depth were neglected.

Leutwyler (1966) further developed the wellbore heat loss modeling effort by including the effects of radiation. However, the changes in pressure and fluid properties were not accounted for in this modeling effort. Leutwyler concluded that casing temperatures could be reduced by emissivity reducing coatings to the tubing, but the reduction in heat flow required a mechanical barrier such as insulation. These results also pointed out that increased annular pressures caused higher heat transfer rates. Other results of this work indicate that the application of an insulating cement sheath outside the casing could lower the heat losses, but would increase the casing temperature. 
The contribution of Host and Flock (1966) attempted to account for frictional pressure losses, using a simple friction factor correlation. However, the frictional pressure loss model did not account for the type of flow regime or slip concept. Also neglected in their model effort were the effects of gravitational pressure changes. Their results indicated that friction could reduce heat losses, and the effect of friction on temperature and steam quality profiles was significant.

Earlougher's (1969) modeling efforts were similar to those of Satter. However, his model included the effect of pressure changes in the injection string and the effect of casing and cement on heat transfer. In Earlougher's model, the Hagedorn and Brown (1965) correlation was implemented to estimate friction pressure losses. This frictional pressure loss model assumes that the Reynold's number exceeds 1,000,000 and slip does not occur between the phases. Results from Earlougher's work indicate that pressure changes cannot be neglected in determining heat transfer, and that frictional pressure losses and gravitational pressure changes should be included.

The next significant modeling effort was by Farouq Ali (1981). His model used mass and momentum balances in the wellbore, and included heat balances in the wellbore and the surrounding medium. Unlike previous models, pressure calculations accounted for slip and the type of flow regime. Heat losses were treated rigorously, and the overall heat transfer coefficient accounted for a variety of well completion types. This model incorporated Pacheco and Farouq Ali's (1974) work and was further updated to include pressure losses and flow regimes using the correlations of Gould et al. (1974), Chierici et al. (1974), and Duns and Ros (1961). Farouq Ali's model yielded good agreement with field data. This work revealed that both the slip and flow regime concepts were essential in the calculation of pressure losses, which in turn were important in determining heat loss. Other results indicated that tubing paint or insulation can result in a significant reduction in heat losses. 
The last model reviewed in this paper was that of Durrant and Thambynayagam (1986). Their model was based on material and momentum balances in the wellbore and a heat balance on the entire system, including the surrounding medium. Transient heat conduction was solved analytically by using Fourier and Laplace transforms. The Gould et al. (1974) and the Beggs and Brill (1973) pressure drop correlations were used to account for pressure losses. These correlations account for slip and different flow regimes.

As shown in the brief literature review, wellbore heat loss models have become more accurate and sophisticated using more advanced numerical solutions with a reduction in the many assumptions. However, discrepancies still exist between observed data and predicted results. The model modified in this study attempts to further improve the wellbore heat loss solution. These refinements were accomplished with the use of several theoretical, semi-theoretical, and mathematical correlations. This model also simulates the flow of steam from the boiler to the formation sandface under a variety of boundary conditions.

\section{Model Description}

The model reported here was originally developed by Jensen and Sharma (1989). Modifications to the original model were incorporated to include multiple tubing and casing strings, as well as the effects of a vacuum, and a convergence scheme for pressure. The model simulates the flow of saturated steam or hot water along a surface line and/or down a wellbore. The simulator can use a variety of surface line configurations that include buried or unburied, and insulated or uninsulated conditions. The wellbore modeling can include single- or double-walled tubing with or without insulation, multiple casing strings, different gases in the casing or tubing annuli with or without a vacuum, and multiple down hole formations. The simulator program is intended to be used with a file utility program and a full screen 
editor. A listing of the source code of the simulator program is given in Appendix B.

The model is a finite difference simulation in length, for a specific time level. It has specifically been designed to simulate the flow of a hot-injection fluid from its source to the sandface. To simulate the transient effects, simulation runs are required for successive time steps. The model listed in Appendix B assumes that the injection fluid is either saturated steam or hot water. But the model is applicable to any hot-injection fluid as long as the correct thermal and physical properties are used.

For each control volume (length or depth) the heat loss and temperature or steam quality was first estimated. Then the pressure drop for each control volume was estimated using either the Lockhart and Martinelli (1949) correlation for two-phase saturated steam or the Moody friction factor (1944) and the Serghides (1984) correlation for single-phase flow. Iterations on pressure were performed until convergence was obtained. During the iteration process, fluid properties were continuously being updated. This pressure loss was used to modify the pressure in each control volume. If the saturated steam regime exists, the saturation temperature is updated according to the new saturation pressure by the use of a steam table. Depending on the fluid condition (saturated steam or hot water), the fluid properties are updated according to the new temperature and pressure by the use of correlations and look-up tables before moving to the next control volume.

A study was performed to determine the optimum control volume size. For a change in control volume size from 10 feet to 1 foot, the change in predicated results was approximately 10 percent. The change in predicated results was less than 1 percent when the control volume size was changed from 1 foot to 0.1 foot. Based on these results, a 1-foot control size was determined to be sufficient for the modeling effort. 
For the estimation of heat loss and pressure change across one control volume, the fluid properties at the inlet of the control volume were used. These properties were assumed to be constant over the control volume. They were updated according to the outlet temperature and pressure from the control volume or used in calculating heat loss and pressure changes in the next control volume. To justify the assumptions of using inlet properties, a study was performed using an iterative loop which averaged the inlet and outlet fluid properties of the control volume. The results of the study indicated that, with a 1 -foot control volume, the change in results was insignificant. The assumption of using inlet conditions was therefore valid.

The assumptions used in this model were: (1) heat is transferred radially away from the pipe, (2) fluid and heat flow are steady-state processes, except for heat loss in the wellbores, (3) the changes in physical and thermal properties are negligible for small intervals of pipe length, but are a function of axial distance, (4) heat transfer in the direction of fluid flow is attributed to only forced convection, and (5) the heat flux batween two specified points is proportional to the temperature difference and inversely proportional to the overall specific thermal resistance.

The correlations used in this modeling effort were obtained from Jensen and Sharma (1987, 1989). These include heat transfer coefficienis for the outside of surface pipes, film heat transfer coefficients for hot water flowing inside a surface pipe or down a well, and local film heat transfer coefficients for condensing steam flowing inside a surface line or down a well. Jensen and Sharma's (1987) worl: showed that the correlations used in this modeling effort were valid for vapor velocities from 20 to 1,000 feet per second, and steam qualities ranging from 0 to 99 percent.

For free convection in the annulus, the coefficients of heat transfer by radiation and convection were estimated using Willhite's (1967) correlations. The thermal conductivity, thermal diffusivity, and transient behavior of the surrounding formations were handled using the dimensionless time function developed by Ramey (1962) and Willhite (1967). 
This new model accuunts for pressure changes resulting from singlephase (hot water) and two-phase systems. From an independent study of friction factors by Jer.sen and Sharma (1987) and the Serghides (1984) friction factor, the correlation factor for single-phase flow was found to be best suited for this model.

\section{Model Sensitivity Analysis}

To evaluate model variation with parameter changes, several different cases were investigated with the numerical model. Heat loss, bottom hole temperature, bottom hole pressure, and steam quality were determined. Input parameters investigated were (1) single tubing versus dual tubing strings configurations, (2) insulation thickness, (3) injection rate (Rate), and (4) injaction temperature $\left(\mathrm{T}_{\mathrm{inj}}\right)$ and pressure $\left(\mathrm{P}_{\mathrm{inj}}\right)$. Other parameters investigated, shown in Tables 3 and 4 but not discussed, included injected steam quality $\left(\mathrm{SQ}_{\mathrm{in}}\right)$, and injection derth (Depth). Numesical results are consistent with the dynamics of the flow and existing discussions found in the literature.

A sensitivity study for a single tubing string was performed. The results are given in Table 3. Other parameters that were not investigated, but entered as input parameters included the heat transfer properties of steel, heat transfer properties of other insulating material other than the referenced material given in the Appendix $\mathrm{C}$, heat transfer properties of surrounding formations, and surface pipe heat loss configurations.

The first three examples of Table 3 represent the effect of insulation thickness on steam quality (SQ) and total heat loss (HL). The results indicate that for constant heat input conditions, heat loss is reduced, resulting in higher steam qualities as the insulation thickness is increased. For example, an insulation thickness of 0.70 inches produced a 3.2 percent heat loss and a steam quality of 75.4 percent. Under the same conditions without any insulation, heat loss was determined to be 3.4 percent with a corresponding steam quality of 75.0 percent. 
Table 3. Single Tubing String Sensitivity Study of Numerical Model Parameters ${ }^{\mathrm{a}}$

\begin{tabular}{|c|c|c|c|c|c|c|c|c|c|}
\hline $\begin{array}{c}\text { Insulation } \\
\text { Thickness, } \\
\text { inch }\end{array}$ & $\begin{array}{c}\text { Rate, } \\
\text { b/d }\end{array}$ & 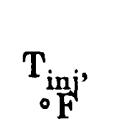 & $\begin{array}{l}P_{\text {injj }} \\
\text { psia }\end{array}$ & $\begin{array}{c}\mathrm{SQ}_{\text {inj }} \\
\%\end{array}$ & $\begin{array}{l}\text { Depth, } \\
\text { feet }\end{array}$ & $\mathrm{T}_{\substack{\mathrm{depth} \\
\circ \mathrm{F}}}$, & $\begin{array}{c}P_{\text {depth }} \\
\text { psia }\end{array}$ & $\underset{\%}{S Q_{\text {depth }}}$ & $\mathrm{HL}$ \\
\hline 0.70 & 350 & 484.9 & 600.0 & 80.0 & 400 & 487.6 & 601.2 & 75.4 & 3.2 \\
\hline 0.50 & 350 & 484.9 & 600.0 & 80.0 & 400 & 487.6 & 601.2 & 75.3 & 3.3 \\
\hline 0.00 & 350 & 484.9 & 600.0 & 80.0 & 400 & 487.6 & 601.2 & 75.0 & 3.4 \\
\hline 0.70 & 300 & 484.9 & 600.0 & 80.0 & 400 & 487.7 & 602.1 & 74.6 & 3.7 \\
\hline 0.70 & 250 & 484.9 & 600.0 & 80.0 & 400 & 487.8 & 602.8 & 73.5 & 4.4 \\
\hline 0.70 & 350 & 484.9 & 600.0 & 70.0 & 400 & 487.6 & 601.5 & 65.4 & 3.4 \\
\hline 0.70 & 350 & 484.9 & 600.0 & 90.0 & 400 & 487.6 & 601.5 & 85.4 & 3.0 \\
\hline 0.70 & 350 & 466.2 & 500.0 & 80.0 & 400 & 468.2 & 500.0 & 75.8 & 3.0 \\
\hline 0.70 & 350 & 444.3 & 400.0 & 80.0 & 400 & 445.5 & 398.7 & 76.3 & 2.7 \\
\hline 0.70 & 350 & 484.9 & 600.0 & 80.0 & 500 & 487.6 & 601.5 & 74.2 & 4.0 \\
\hline 0.70 & 350 & 484.9 & 600.0 & 80.0 & 600 & 487.7 & 601.8 & 73.1 & 4.7 \\
\hline
\end{tabular}

a performed with single tubing string (2.992-inch i.d. $x$ 3.500-inch o.d.) in casing (4.950inch i.d. $x$ 5.500-inch o.d.) cemented in an 8.017-inch hole for 365 days

Injection rates were varied from 250 to 350 barrels per day of cold water. The results show that as the injection rate was increased, the temperature $\left(\mathrm{T}_{\text {depth }}\right)$ and steam quality $\left(\mathrm{SQ}_{\text {depth }}\right)$ at the bottom hole depth increased, resulting in a reduction in the net heat loss. There are two reasons for this reduced heat loss. First, the duration of time for which the injection fluid is exposed to the temperature difference between the injection fluid and the surrounding formations decreases with increasing flow rates, thus reducing the total heat loss per unit mass of steam. Second, the frictional pressure drop increases with increasing flow rates, reducing the rate of decline of the saturation temperature and pressure, resulting in a reduced heat flux per unit mass of steam. 
Another phenomena predicted by the model is the existence of a critical flow rate below which adverse conditions persist, an interesting aspect of wellbore heat transfer not normally found in the literature. This phenomena shows that saturation pressures and temperatures are larger at the stated depth than under wellhead injection conditions. This condition is caused from the gravitational pressure increase being greater than the frictional pressure drop, causing the absolute pressure going down the well to increase. This increase in absolute pressure increases the saturation temperature, which in turn affects the fluid properties, such as density, viscosity, thermal conductivity, and latent heat of vaporization. The latent heat of vaporization decreases with increasing saturation temperature, causing the rate of steam condensation to increase as the pressure and temperature increase. This increase in condensation causes the pressure gradient to become even more dominant, thus creating an adverse spiral of events. In most of the cases examined, these conditions existed and this phenomena indeed occurred.

Further numerical modeling studies were performed using a doublewalled tubing string. The results of this sensitivity study are given in Table 4. The parameters investigated include those given in Table 3, as well as different insulating configurations of the double-walled tubing. Insulating configurations used were air and/or insulation in the annulus and around the pipe.

The results obtained using the double-walled pipe were consistent with those using the single tubing string. However, by using insulation instead of air in the annulus of the double-walled tubing, a heat loss reduction of more than 50 percent ( 2.8 to 1.3 percent) was observed. The addition of insulation around the outer pipe resulted in only a minor reduction in the heat loss (1.3 to 1.2 percent). 
Table 4. Double-Walled Tubing String Sensitivity Study of Numerical Model Parameters ${ }^{\mathrm{a}}$

\begin{tabular}{|c|c|c|c|c|c|c|c|c|c|}
\hline $\begin{array}{c}\text { Tubing } \\
\text { Annulus } \\
\text { Insulation } \\
\text { Material }\end{array}$ & $\begin{array}{c}\text { Rate, } \\
\text { b/d }\end{array}$ & 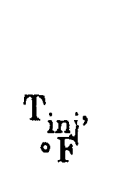 & $\begin{array}{l}P_{\text {injj }} \\
\text { psia }\end{array}$ & $\begin{array}{c}\mathrm{SQ}_{\text {inj, }} \\
\%\end{array}$ & $\begin{array}{l}\text { Depth, } \\
\text { feet }\end{array}$ & $\mathrm{T}_{\substack{\text { depth } \\
\circ \mathrm{F}}}$ & $\begin{array}{l}P_{\text {depth' }} \\
\text { psia }\end{array}$ & $\mathrm{SQ}_{\mathrm{depth}}$ & $\begin{array}{r}\mathrm{HL} \\
\%\end{array}$ \\
\hline insul $^{b}$ & 350 & 484.9 & 600.0 & 80.0 & 400 & 487.6 & 601.2 & 78.1 & 1.3 \\
\hline air ${ }^{c}$ & 350 & 484.9 & 600.0 & 80.0 & 400 & 487.6 & 601.2 & 76.0 & 2.8 \\
\hline $\operatorname{air}^{-i n s u l}{ }^{d}$ & 350 & 484.9 & 600.0 & 80.0 & 400 & 487.6 & 601.2 & 76.8 & 2.2 \\
\hline ins-ins $^{e}$ & 350 & 484.9 & 600.0 & 80.0 & 400 & 487.6 & 601.2 & 78.3 & 1.2 \\
\hline insul $^{b}$ & 300 & 484.9 & 600.0 & 80.0 & 400 & 487.7 & 602.8 & 77.8 & 1.5 \\
\hline insul $^{b}$ & 250 & 484.9 & 600.0 & 80.0 & 400 & 487.8 & 602.8 & 77.3 & 1.8 \\
\hline insul $^{b}$ & 350 & 466.2 & 500.0 & 80.0 & 400 & 468.2 & 500.0 & 78.2 & 1.3 \\
\hline insul $^{b}$ & 350 & 444.3 & 400.0 & 80.0 & 400 & 445.5 & 398.8 & 78.4 & 1.2 \\
\hline insul $^{b}$ & 350 & 484.9 & 600.0 & 70.0 & 400 & 487.6 & 601.4 & 68.1 & 1.4 \\
\hline insul $^{b}$ & 350 & 484.9 & 600.0 & 90.0 & 400 & 487.6 & 601.6 & 88.1 & 1.2 \\
\hline insul $^{b}$ & 350 & 484.9 & 600.0 & 80.0 & 500 & 487.7 & 602.0 & 87.6 & 1.5 \\
\hline insul $^{b}$ & 350 & 484.9 & 600.0 & 80.0 & 600 & 487.8 & 602.3 & 87.1 & 1.8 \\
\hline
\end{tabular}

a performed with double-walled tubing string (2.992-inch i.d. $\times$ 3.500-inch o.d. inner string) and (4.950-inch i.d. $\times 5.500$-inch o.d. outer string) in casing (8.017-inch i.d. $\times$ 8.625-inch o.d.) cemented in a 11.00-inch hole for 365 days

b insulation in the double-walled tubing annulus

c air in the double-walled tubing annulus

d air in double-walled tubing annulus and 2 inches of insulation around outer tubing string

e insulation in double-walled tubing annulus and 2 inches of insulation around outer tubing string 
To determine the effects of time and to provide a comparison of the single tubing string to the double-walled tubing string, numerical simulations were performed with constant input parameters for various completion cases to a depth of 4,000 feet. The completion cases were:

Case A - Single tubing string (2.992 inches $\mathrm{x} 3.500$ inches) with casing (8.017 inches x 9.625 inches) cemented in an 11.000-inch hole;

Case B - Single tubing string (2.992 inches $x 3.500$ inches) with 2.0 inches of external insulation, with casing ( 8.017 inches $x 8.625$ inches) cemented in an 11.000-inch hole;

Case C - Double-walled tubing string (inner pipe -2.992 inches $\mathrm{x} 3.500$ inches, outer pipe -4.950 inches $\times 5.500$ inches) with casing $(8.017$ inches x 8.625 inches) cemented in an 11.000-inch hole;

Case D - Double-walled tubing string (inner pipe -2.992 inches x 3.500 inches, outer pipe -4.950 inches $\times 5.500$ inches) with annular insulation, with casing ( 8.017 inches $x 8.625$ inches) cemented in an 11.000-inch hole;

Case $\mathrm{E}$ - Double-walled tubing string (inner pipe -2.992 inches x 3.500 inches, outer pipe - 4.950 inches $x 5.500$ inches) with annular insulation, with 2.0-inch external insulation, with casing (8.017 inches $x 8.625$ inches) cemented in an 11.000-inch hole;

The results of these cases are shown in Figures 8 and 9 for heat losses and steam quality as a function of time, respectively.

To provide a comparison of each case, the average heat loss and average steam quality of the 1000 day injection period were computed using a trapezoid computational method. In Figure 8, the difference in heat loss of Case D (annular insulated double-walled tubing string) compared to Case A 


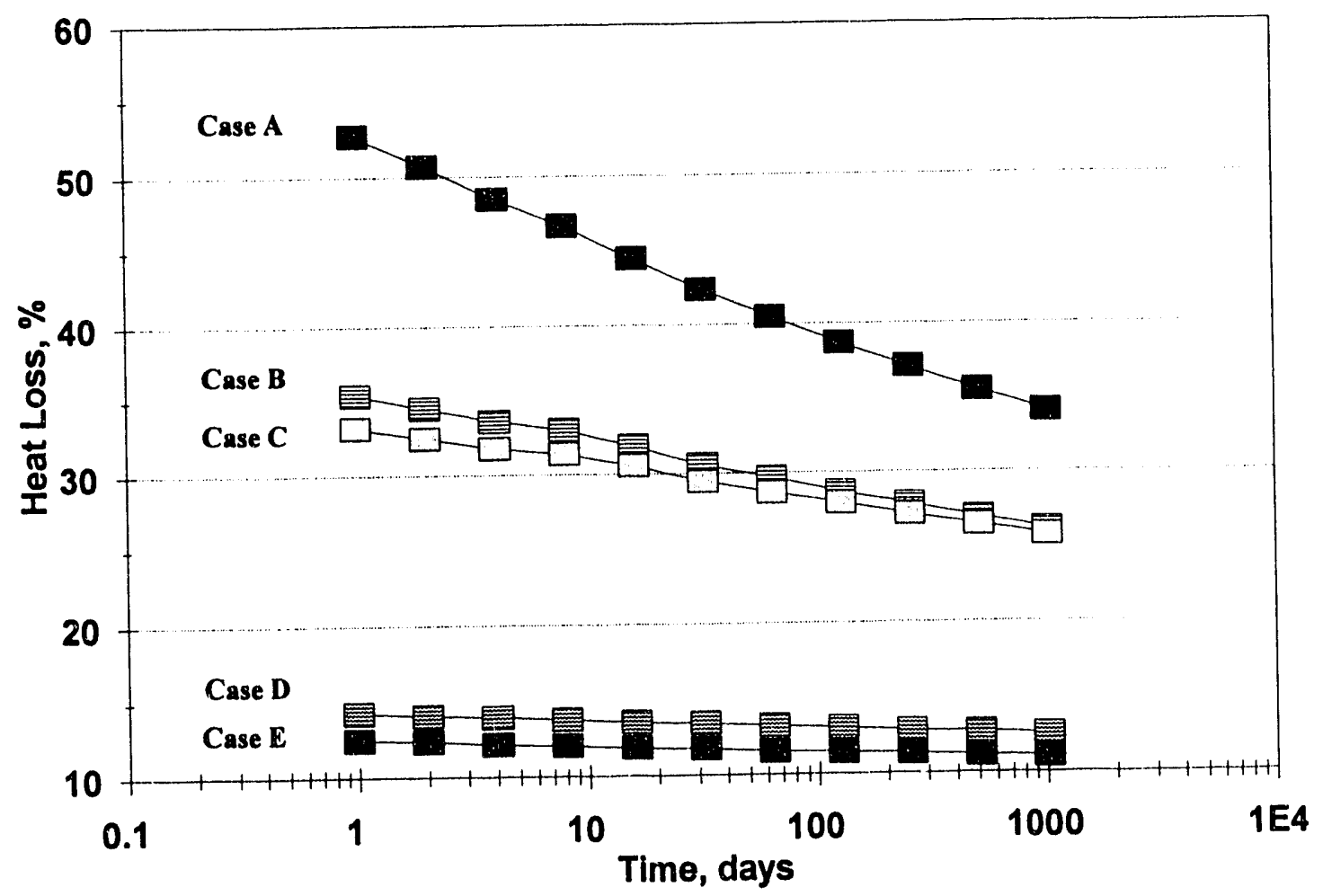

Figure 8. Case Studies of Heat Losses

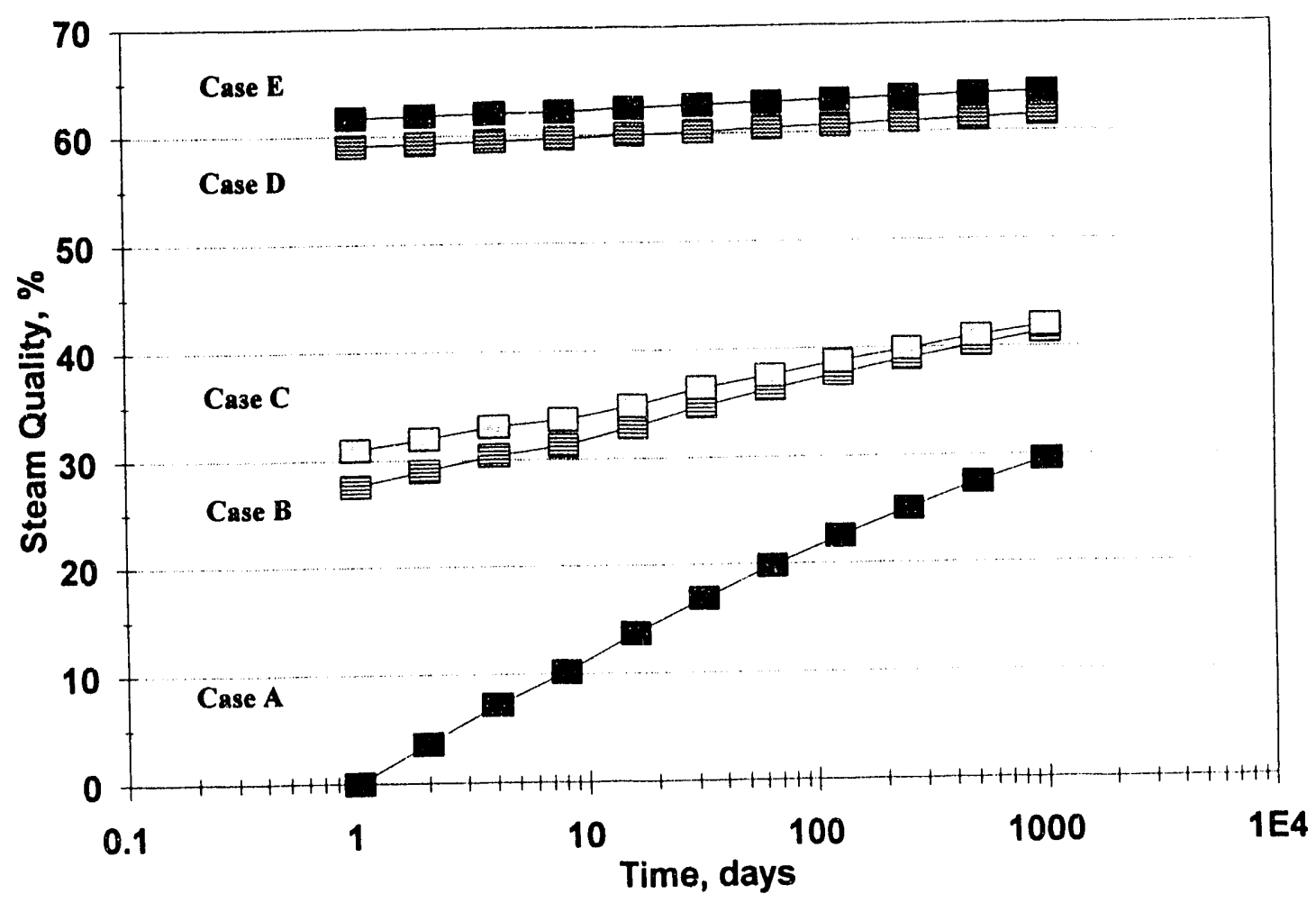

Figure 9. Case Studies of Steam Quality 
(single tubing string) is reduced by approximately 30 percent during the entire injection period. At the heat injection rate of 1502.2 Btu per second, the use of Case $\mathrm{D}$ tubing completion results in a heat loss reduction of 38.937 $x 1010 \mathrm{Btu}$. If propane were used as fuel at a cost of $\$ 2.76$ per pound $(\$ 0.65$ per gallon) and a net heat of combustion of 19,944 Btu per pound, a fuel savings of more than $\$ 5.3$ million dollars could be realized. Comparing Case $\mathrm{B}$ (insulated single tubing string) to Case $\mathrm{D}$ with the same parameters, a fuel savings of more than $\$ 2.8$ million could be realized using the annularinsulated double-walled tubing string.

A case-by-case depiction of reducing this heat loss as a function of steam quality is illustrated in Figure 9. In Figure 9, an average increase of steam quality of 44 percent, using the trapezoid computational method, is obtained when comparing Case D to Case A. This increased steam quality would result in increased production rates as well as higher ultimate recoveries.

Other significant results shown in both Figures 8 and 9 are little net change in heat loss and steam quality by using external insulation (Case $\mathrm{E}$ to Case D). Another interesting result is a small difference in steam quality and heat loss between the non-insulated double-walled tubing string and the insulated single tubing string.

\section{Model Verification}

The task of measuring steam quality at various depths in a wellbore is a complex and separate project by itself. However, published field data for steam temperature was used for the validation of this model and also as a comparison to previously published models.

The new model developed for this project predicts the field data better than the two previously published models, as shown in Figure 10. Figure 10 shows the steam temperature as a function of depth using the data from Well No. 61-0, Martha Bigpond Field, Oklahoma as reported by Bleakley (1964). 
During this field project, steam was injected at 80 percent quality at a rate of 4,850 pounds per hour through 2 -inch tubing for a period of 5 days. As shown in Figure 10, the predictions of the Farouq Ali (1981) model deviate away from the field data at a depth of 800 feet, and continue to increase in error to the total depth of the well. The Durrant and Thambynayagam (1986) model maintains a constant error from the surface to total depth. Even though the steam temperatures predicted by the other models differ by only a small amount from the measured steam temperatures, the differences will be greater for the predicted saturation pressures. For example, at a saturation temperature of $380^{\circ} \mathrm{F}\left(193^{\circ} \mathrm{C}\right)$, a difference in temperature of $4^{\circ} \mathrm{F}\left(2.2^{\circ} \mathrm{S}\right)$ equivalent to a difference of 10 psia in the saturation pressure. A comparison of these models to the new model shows that the steam qualities differ by more than 30 percent at steam qualities lower than 0.35. These differences may be attributed to two-phase frictional pressure predictions and the physical and thermal property correlations used.

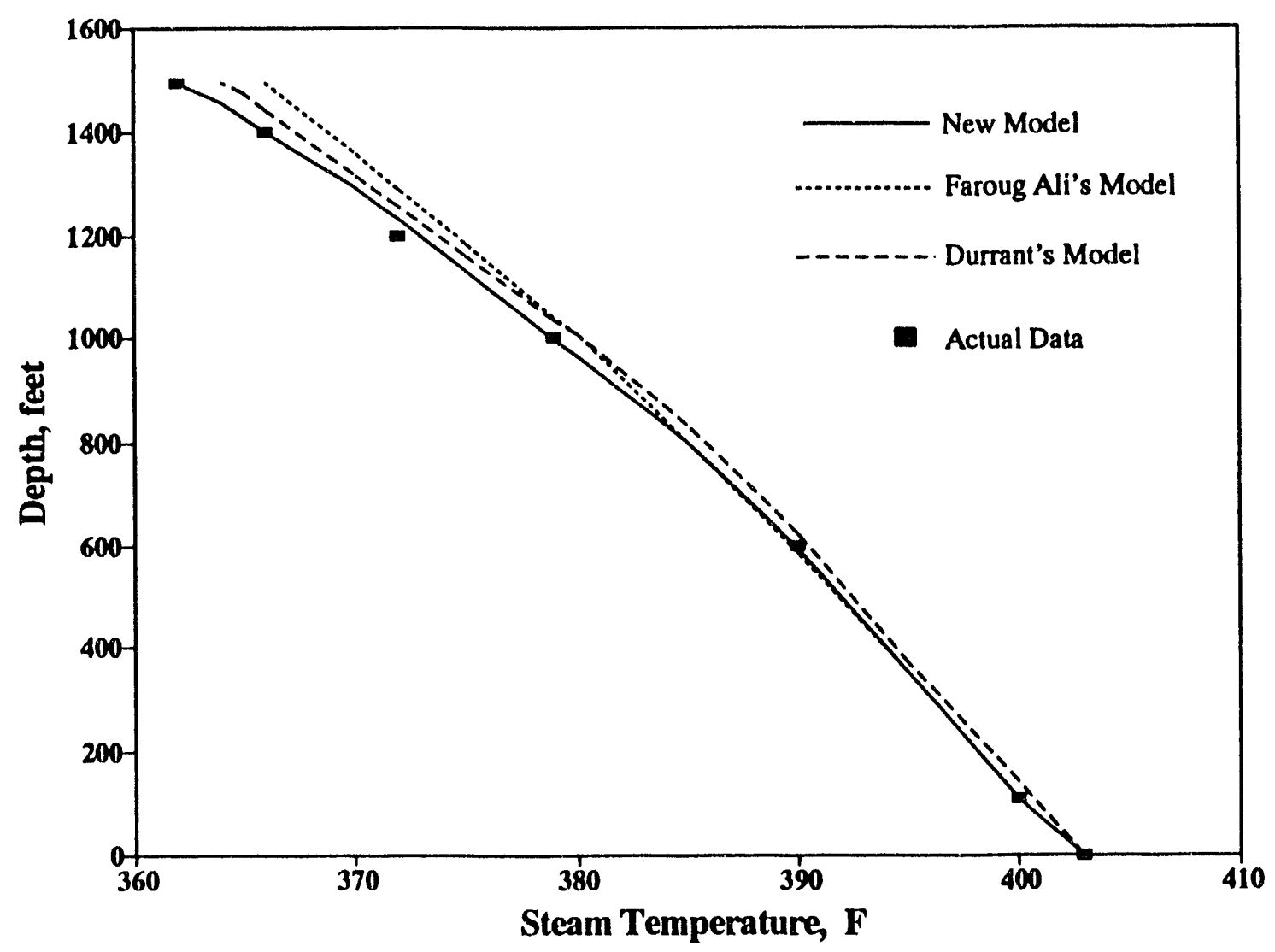

Figure 10. Numerical Model Comparisons 


\section{CONCLUSIONS AND RECOMMENDATIONS}

Heat losses were determined for four different configurations of the double-walled tubular product provided by the Inter-Mountain Pipe Company. A flow loop was constructed to develop a data base for the evaluation of the thermal properties of the pipe. Also performed in this work, was the development of a thermal hydraulics simulator.

The results of the flow loop showed that:

1. Of the variables tested, only location (coupling or body) and insulation (installed or not installed) were found to affect heat losses. Other insignificant variables tested included: test number, test section (horizontal or vertical), and vacuum (applied or not applied).

2. By applying insulation in the annular portion of the double-walled pipe, pipe body heat loss rates were reduced by 98 percent as compared to the uninsulated cases.

3. In the 3-feet-long test section, the average heat loss rate of the insulated pipe body was 105 Btu per hour.

4. The insulated pipe coupling heat loss rates were considerably higher than the pipe body. The heat loss rates were reduced by only 6 percent when the insulation was applied to the coupling.

5. Tests requiring a vacuum of 0.1 torr in the annulus were not achieved because of leaks. A vacuum of 1.0 psia was not effective in reducing the heat loss rate which was consistent with the literature. 
The pipe body with insulation in the annular portion of the pipe was effective in reducing the heat losses during the physical simulations. However, the coupling heat losses need to be reduced to at least a value comparable to pipe body.

The coupling heat losses can be reduced by: (1) incorporating a thermal resistant support, instead of the presently used carbon steel support ring, and/or (2) by incorporating a smaller cross-section area in the new or existing ring. The change in cross-section area may be accomplished with the use of knife edges. An alternate solution would require a new design which would eliminate the metal to metal contact between the two pipes in the coupling area.

A modification of the seals used in the coupling design is recommended. The seal modification is required to ensure that the steam does not leak into the annular portion of the pipe. In addition, a positive (pressure-vacuum) seal would also allow a vacuum to be maintained in the annular portion of the pipe. By lowering and maintaining the annular pressure at a vacuum less than 0.1 torr, further improvements in heat loss rates should be possible.

A new model for simulating the thermal hydraulics of saturated steam, or hot water from the heat source (steam generator or boiler) to the sandface of a reservoir was developed. The model extends the understanding of the various modes of heat transfer to the wellbore thermal hydraulics problem. The model includes two-phase frictional pressure drop calculations which allow for slip and local two-phase fluid film heat transfer coefficients. The model also has provisions that allow for a variety of surface pipe and wellbore boundary conditions to be incorporated. 
Sensitivity studies showed that the heat loss experienced by the injection fluid decreased with an increase in either injection rate, insulation thickness, or injection time. The model predicts that a minimum injection rate exists below which severe heat loss occurs. The depth at which these adverse effects occur can be determined using the model.

The predictions of the model were compared with those of previous models and with actual steam temperature field data. The new model compares excellently with the previous published models in a specified range of operating conditions. In the case of evaluation with actual field data, this new model predicted the field data over a wider range of operating ranges with better accuracy than any of the previously published models. 


\section{ACKNOWLEDGEMENTS}

The authors express appreciation to the United States Department of Energy (Cooperative Agreement Number DE-FC21-86MC11076) and to InterMountain Pipe Company for funding of this work. Special thanks are extended to Mr. Thayne Routh for his assistance in modifying the model.

\section{DISCLAIMER}

Mention of specific brand names or models of equipment is for information only and does not imply endorsement of any particular brand. 


\section{REFERENCES}

Beggs, H.D., and Brill, J.P., 1973, A Study of Two-Phase Flow in Inclined Pipes. J. Pet. Tech., 25(5): 607-617.

Bleakley, W.B., 1964, Here Are Case Histories of Two Thermal Projects. Oil and Gas J., October 26, 123-130.

Chierici, G.L., Ciucci, G.M., and Sclocchi, G., 1974, Two-Phase Flow in Oil Wells - Predictions of Pressure Drop. J. Pet. Tech., 26(8): 927-938.

Durrant, A.J., and Thambynayagam, R.G.M., 1986, Wellbore Heat Transmission and Pressure Drop for Steam/Water Injection and Geothermal Production, A Simple Solution Technique. SPE Reservoir Engineering, 1(2): 148-162.

Duns, H. Jr., and Ros, N.C., 1961, Vertical Flow of Gas and Liquid Mixtures in Wells. Proc., Sixth World Pet. Congress, Frankfurt, Sec. II, Paper 22PD6, 451-465.

Earlougher, R.C. Jr., 1969, Some Practical Considerations in the Design of Steam Injection Wells. J. Pet. Tech., 21(1): 79-86.

Farouq Ali, S.M., 1981, A Comprehensive Wellbore Steam/Water Flow Model for Steam Injection and Geothermal Applications. J. Pet.Tech., 33(10): 527-534.

Gould T.L., Tek, M.R., and Katz, D.L., 1974, Two-Phase Flow Through Vertical. Inclined, or Curved Pipe. J. Pet.Tech., 26(8): 915-926.

Hagedorn, A.R., and Brown, K.E., 1965, Experimental Study of Pressure Gradients Occurring During Continuous Flow in Small Diameter Conduits. J. Pet.Tech., 17(4): 475-484.

Hines, William W. and Montgomery, D.C., 1980, Probability and Statistics in engineering and Management Science, 2nd edition. John Wiley and Sons, New York.

Host, P.H., and Flock, D.L., 1966, Wellbore Behavior During Saturated Steam Injection. J. Cdn. Pet. Tech., 5(4): 184.

Jensen, T.B., and Sharma, M.P., 1989, Thermal Hydraulics of Wellbore and Surface Lines During Steam/Hot Water Injection - Part I: Theoretical Model. J. Eng. Resour. Tech., 111(2): 55-63. 
Jensen, T.B., and Sharma, M.P., 1987, Analysis of Friction Factor and Equivalent Diameter Correlations. Presented at the ASME Petroleum Division ETCE Conference, February 15-20, Dallas, TX.

Leutwyler, K., 1966, Casing Temperature Studies in Steam Injection Wells. J.Pet.Tech., 18(9): 1157-1162.

Lockhart, R.W., and Martinelli, R.C., 1949, Proposed Correlation of Data for Isothermal Two-phase, Two Component Flow in Pipes. Chemical Engineering Progress, 45(1): 39-48.

Moody, L.F., 1944, Friction Factors for Pipe Flow. Trans A.S.M.E, 66: 671.

Moss, J.T., and White, P.D., 1959, How to Calculate Temperature Profiles in a Water-Injection Well. Oil and Gas J., 57(11): 174.

Pacheco, E.F., and Farouq Ali, S.M., 1974, Wellbore Heat Losses and Pressure Drop in Steam Injection. J. Pet.Tech., 26(8): 915-926.

Perry, R.H., and Green, D.W., 1984, Perry's Chemical Engineering Handbook, 6th Edition. McGraw Hill Book Company, New York.

Ramey, H.J. Jr., 1962, Wellbore Heat Transmission. J. Pet.Tech., 14(4): 427435.

Satter, A, 1963, Heat Losses During Flow of Steam Down a Wellbore. J. Pet.Tech., 15(7): 845-851.

Serghides. C.K., 1984, Estimate Friction Factors Accurately. Chemical Engineering, March 4, 63-64.

Ullman, N.R., 1972, Statistics: An Applied Approach. Xerox College Publishing, Mass.

Willhite, G.P., 1967, Over-All Heat Transfer Coefficients in Steam and Hot Water Injection Wells. J. Pet.Tech., 19(5): 607-615. 


\section{APPENDIX A}

Experimental Data 


\section{CONTENTS OF APPENDIX A}

\section{Table}

$\underline{\text { Page }}$

1. Flowloop Run \#1.................................................................... 36

2. Flowloop Run \#2

3. Flowloop Run \#3........................................................................ 40

4. Flowloop Run \#4...................................................................... 42

5. Flowloop Run \#5.......................................................................... 44 


\section{Table 1 : Flowloop Run \#1}

Test Conditions:

Vertical Test Section - no insulation - no vacuum - no coupling insualtion

Horizontal Test Section - with insulation - no vacuum - no coupling insulation

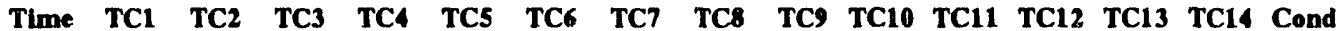

\begin{tabular}{|c|c|c|c|c|c|c|c|c|c|c|c|c|c|c|c|}
\hline 0 & 66 & 58 & 58 & 58 & 59 & 64 & 61 & 242 & 61 & 88 & 61 & 70 & 92 & 63 & $\overline{65}$ \\
\hline 5 & 275 & 62 & 140 & 106 & 256 & 275 & 61 & 275 & 78 & 225 & 119 & 253 & 270 & 63 & 66 \\
\hline 10 & 272 & 66 & 142 & 144 & 259 & 273 & 62 & 273 & 92 & 226 & 155 & 258 & 273 & 65 & 64 \\
\hline 15 & 268 & 71 & 143 & 163 & 258 & 269 & 62 & 269 & 103 & 226 & 173 & 258 & 269 & 66 & 81 \\
\hline $2 C$ & 271 & 77 & 146 & 173 & 262 & 272 & 63 & 272 & 112 & 230 & 183 & 261 & 272 & 66 & 114 \\
\hline 25 & 279 & 82 & 152 & 180 & 268 & 280 & 64 & 280 & 121 & 238 & 191 & 269 & $28 \sigma$ & 68 & 31 \\
\hline 30 & 275 & 88 & 154 & 187 & 266 & 275 & 64 & 275 & 128 & 237 & 197 & 267 & 276 & 69 & \\
\hline 35 & 268 & 92 & 154 & 190 & 262 & 269 & 64 & 269 & 133 & 233 & 199 & 262 & 269 & 70 & 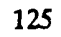 \\
\hline 40 & 271 & 96 & 157 & 190 & 263 & 271 & 63 & 272 & 136 & 235 & 199 & 264 & 272 & 68 & 26 \\
\hline 45 & 279 & 100 & 163 & 194 & 270 & 280 & 64 & 280 & 140 & 242 & 202 & 271 & 280 & 66 & 43 \\
\hline 50 & 275 & 103 & 164 & 196 & 267 & 275 & 64 & 275 & 143 & 240 & 205 & 268 & 276 & 68 & 43 \\
\hline 55 & 266 & 106 & 162 & 196 & 261 & 266 & 65 & 266 & 144 & 234 & 205 & 261 & 267 & 70 & 130 \\
\hline 60 & 271 & 108 & 164 & 195 & 264 & 272 & 66 & 272 & 146 & 238 & 203 & 264 & 272 & 73 & 134 \\
\hline 65 & 280 & 110 & 169 & 196 & 271 & 280 & 63 & 281 & 147 & 244 & 204 & 272 & 281 & 71 & 51 \\
\hline 70 & 275 & 111 & 168 & 198 & 268 & 275 & 62 & 275 & 148 & 242 & 206 & 269 & 276 & 6 & 47 \\
\hline 75 & 265 & 112 & 165 & 197 & 260 & 266 & 60 & 266 & 147 & 235 & 205 & 261 & 267 & 3 & 133 \\
\hline 80 & 272 & 113 & 167 & 195 & 264 & 272 & 59 & 272 & 146 & 238 & 203 & 265 & 273 & 65 & 138 \\
\hline 85 & 280 & 113 & 171 & 196 & 272 & 281 & 58 & 281 & 146 & 245 & 205 & 273 & 281 & 39 & 155 \\
\hline 90 & 274 & 114 & 169 & 199 & 268 & 2.75 & 63 & 275 & 147 & 241 & 207 & 268 & 275 & 68 & 148 \\
\hline 95 & 266 & 115 & 167 & 197 & 261 & 266 & 66 & 267 & 147 & 235 & 205 & 261 & 267 & 13 & 150 \\
\hline 100 & 271 & 116 & 168 & 196 & 263 & 271 & 65 & 271 & 147 & 238 & 204 & 264 & 272 & 11 & 30 \\
\hline 105 & 279 & 116 & 172 & 197 & 271 & 280 & 63 & 280 & 148 & 244 & 205 & 272 & 280 & 67 & JJ \\
\hline 110 & 275 & 117 & 172 & 200 & 268 & 275 & 64 & 275 & 149 & 242 & 207 & 269 & 276 & 69 & .51 \\
\hline 115 & 267 & 117 & 169 & 199 & 262 & 268 & 67 & 268 & 149 & 236 & 207 & 262 & 268 & 71 & 140 \\
\hline 120 & $26^{\circ}$ & 117 & 169 & 197 & 263 & 270 & 65 & 270 & 150 & 237 & 205 & 263 & 271 & 69 & 138 \\
\hline 125 & 278 & 117 & 173 & 198 & 270 & 279 & 62 & 279 & 149 & 244 & 206 & 271 & 280 & 67 & 54 \\
\hline 130 & 275 & 118 & 173 & 200 & 269 & 276 & 64 & 276 & 150 & 243 & 207 & 270 & 277 & 69 & .54 \\
\hline 135 & 268 & 118 & 170 & 200 & 263 & 269 & 67 & 269 & 150 & 238 & 207 & 264 & 269 & 73 & 42 \\
\hline 140 & 268 & 118 & 169 & 197 & 262 & 269 & 66 & 269 & 150 & 236 & 206 & 262 & 269 & 70 & 37 \\
\hline 145 & 277 & 119 & 173 & 199 & 270 & 278 & 63 & 278 & 150 & 243 & 206 & 270 & 278 & 68 & 52 \\
\hline 150 & 276 & 119 & 174 & 201 & 270 & 277 & 66 & 277 & 151 & 243 & 207 & 271 & 277 & 72 & \\
\hline 155 & 270 & 119 & 171 & 201 & 265 & 270 & 67 & 270 & 151 & 239 & 208 & 265 & 271 & 70 & \\
\hline 160 & 267 & 119 & 169 & 199 & 261 & 268 & 63 & 268 & 151 & 236 & 205 & 262 & 269 & 69 & 137 \\
\hline 165 & 276 & 119 & 173 & 198 & 269 & 277 & 68 & 277 & 151 & 242 & 207 & 269 & 277 & 71 & 151 \\
\hline 170 & 277 & 119 & 174 & 201 & 270 & 277 & 65 & 278 & 151 & 244 & 209 & 271 & 278 & 68 & \\
\hline 175 & 271 & 119 & 172 & 201 & 265 & 271 & 64 & 272 & 151 & 239 & 208 & 266 & 272 & 68 & \\
\hline 180 & 265 & 119 & 169 & 200 & 259 & 266 & 65 & 266 & 151 & 235 & 206 & 260 & 266 & 70 & \\
\hline 18 & 274 & 119 & 172 & 198 & 267 & 275 & 68 & 275 & 151 & 241 & 206 & 268 & 275 & 71 & \\
\hline
\end{tabular}

rms/WRI 92 
Table 1 : Flowloop Run \#1 (cont.)

Test Conditions:

Vertical Test Section - no insulation - no vacuum - no $\mathrm{cou}_{2}$,ling insualtion

Horizontal Test Section - with insulation - no vacuum - no coupling insulation

Time TC1 TC2 TC3 TC4 TC5 TC6 TC7 TC8 TC9 TC10 TC11 TC12 TC13 TC14 Cond

\begin{tabular}{|c|c|c|c|c|c|c|c|c|c|c|c|c|c|c|c|}
\hline$\overline{190}$ & 278 & 119 & $\overline{175}$ & 200 & 271 & 279 & $\overline{66}$ & $\overline{279}$ & $\overline{151}$ & 245 & 208 & 272 & 279 & 69 & 174 \\
\hline 195 & 272 & 119 & 172 & 201 & 266 & 272 & 64 & 272 & 151 & 240 & 208 & 267 & 273 & 68 & 161 \\
\hline 200 & 264 & 119 & 169 & 200 & 260 & 265 & 65 & 265 & 151 & 234 & 207 & 260 & 265 & 69 & 146 \\
\hline 205 & 272 & 119 & 171 & 197 & 265 & 273 & 68 & 273 & 151 & 239 & 207 & 266 & 273 & 70 & 157 \\
\hline 210 & 280 & 119 & 175 & 199 & 273 & 280 & 66 & 281 & 151 & 246 & 208 & 273 & 281 & 70 & 179 \\
\hline 215 & 273 & 119 & 173 & 201 & 268 & 274 & 64 & 274 & 151 & 241 & 208 & 268 & 275 & 7 & 165 \\
\hline 220 & 265 & 119 & 169 & 200 & 260 & 265 & 64 & 265 & 151 & 235 & 207 & 261 & 26 & 8 & 150 \\
\hline 225 & 271 & 119 & 171 & 198 & 264 & 272 & 66 & 272 & 15 & 239 & 206 & 26 & 272 & 0 & 56 \\
\hline 230 & 280 & 119 & 175 & 198 & 272 & 28 & 68 & 280 & 15 & 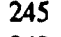 & 208 & 273 & 281 & 1 & 75 \\
\hline 235 & 274 & 120 & 173 & 201 & 268 & 275 & 66 & 275 & 152 & 242 & 208 & 269 & 275 & 0 & 167 \\
\hline 240 & 266 & 119 & 170 & 201 & 261 & 267 & 04 & 267 & 151 & 236 & 208 & 262 & 201 & 8 & 153 \\
\hline 245 & 270 & 119 & 171 & 199 & 264 & 271 & 65 & 271 & 151 & 238 & 205 & 264 & 271 & 88 & 155 \\
\hline 250 & 279 & 119 & 174 & 199 & 271 & 279 & 66 & 280 & 151 & 245 & 207 & 272 & 280 & 0 & 173 \\
\hline 255 & 275 & 120 & 173 & 201 & 269 & 275 & 68 & 275 & 152 & 242 & 208 & 269 & 27 & 1 & 169 \\
\hline 260 & 265 & 120 & 170 & 199 & 261 & 266 & 65 & 266 & 151 & 236 & 208 & 261 & 266 & 7 & 152 \\
\hline 265 & 272 & 119 & 171 & 199 & 265 & 272 & 65 & 272 & 151 & 239 & 206 & 265 & 27 & 8 & 158 \\
\hline 270 & 280 & 119 & 175 & 200 & 273 & 280 & 65 & 281 & 151 & 246 & 207 & 273 & 281 & 0 & 181 \\
\hline 275 & 273 & 120 & 173 & 200 & 268 & 274 & 68 & 274 & 152 & 242 & 209 & 268 & 275 & 71 & 167 \\
\hline 280 & 265 & 120 & 169 & 200 & 260 & 266 & 66 & 266 & 152 & 235 & 207 & 260 & 267 & 70 & 149 \\
\hline 285 & 274 & 119 & 172 & 199 & 267 & 274 & 64 & 275 & 151 & 241 & 206 & 267 & 275 & 68 & 163 \\
\hline 290 & 278 & 120 & 175 & 201 & 272 & 279 & 65 & 279 & 152 & 245 & 208 & 272 & 280 & 69 & 182 \\
\hline 295 & 271 & 120 & 172 & 201 & 266 & 272 & 67 & 272 & 152 & 240 & 209 & 267 & 272 & 1 & 164 \\
\hline 300 & 267 & 120 & 169 & 199 & 261 & 267 & 68 & 267 & 151 & 236 & 207 & 261 & 268 & 1 & 149 \\
\hline 305 & 275 & 120 & 173 & 198 & 268 & 276 & 65 & 276 & 151 & 242 & 207 & 269 & 276 & 69 & 165 \\
\hline 310 & 277 & 120 & 174 & 201 & 271 & 278 & 64 & 278 & 152 & 244 & 207 & 271 & 278 & 8 & 177 \\
\hline 315 & 270 & 120 & 172 & 201 & 265 & 271 & 65 & 271 & 152 & 239 & 208 & 266 & 271 & 9 & 162 \\
\hline 320 & 268 & 120 & 170 & 199 & 261 & 268 & 67 & 268 & 151 & 236 & 207 & 262 & 269 & 0 & 51 \\
\hline 325 & 276 & 119 & 173 & 198 & 269 & 277 & 68 & 277 & 151 & 243 & 207 & 270 & 78 & 71 & 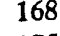 \\
\hline 330 & 276 & 120 & 174 & 200 & 270 & 277 & 67 & 277 & 152 & 244 & 209 & 271 & 278 & 1 & 175 \\
\hline 335 & 200 & 20 & 70 & 201 & 256 & 201 & 65 & 9 & 151 & 232 & 208 & 2 & 241 & 9 & 152 \\
\hline
\end{tabular}

rms/WRI 92 


\section{Table 2 : Flowloop Run \#2}

Test Conditions:

Vertical Test Section - no insulation - with vacuum - no coupling insulation

Horizontal Test Section - with insulation - with vacuum - no coupling insulation

Time TC1 TC2 TC3 TC4 TC5 TC6 TC7 TC8 TC9 TC10 TC11 TC12 TC13 TC14 Cond

\begin{tabular}{|c|c|c|c|c|c|c|c|c|c|c|c|c|c|c|c|}
\hline & & & & & & & & & & & & & & & \\
\hline$\overline{0}$ & 202 & 73 & 134 & 153 & 210 & 203 & 65 & 248 & 119 & 210 & 168 & 202 & 203 & 69 & 62 \\
\hline 5 & 194 & 77 & 124 & 151 & 196 & 200 & 64 & 228 & 121 & 199 & 161 & 197 & 196 & 68 & 64 \\
\hline 10 & 185 & 80 & 122 & 148 & 191 & 188 & 64 & 220 & 122 & 190 & 160 & 193 & 192 & 65 & 66 \\
\hline 15 & 178 & 82 & 120 & 144 & 183 & 174 & 64 & 215 & 122 & 181 & 156 & 183 & 184 & 68 & 68 \\
\hline 20 & 278 & 85 & 143 & 141 & 250 & 279 & 66 & 279 & 122 & 232 & 151 & 248 & 279 & 68 & 68 \\
\hline 25 & 273 & 88 & 157 & 162 & 264 & 273 & 67 & 274 & 127 & 235 & 176 & 265 & 274 & 69 & 114 \\
\hline 30 & 265 & 92 & 156 & 176 & 258 & 265 & 66 & 265 & 131 & 230 & 186 & 258 & 266 & 71 & 115 \\
\hline 35 & 269 & 95 & 158 & 182 & 261 & 269 & 65 & 269 & 133 & 233 & 192 & 261 & 270 & 66 & 119 \\
\hline 40 & 276 & 98 & 163 & 187 & 269 & 277 & 65 & 277 & 137 & 239 & 196 & 269 & 278 & 69 & 135 \\
\hline 45 & 276 & 101 & 165 & 192 & 270 & 277 & 65 & 277 & 140 & 240 & 202 & 270 & 277 & 67 & 144 \\
\hline 50 & 268 & 103 & 163 & 194 & 262 & 268 & 66 & 268 & 142 & 235 & 203 & 263 & 268 & 68 & 132 \\
\hline 55 & 269 & 105 & 164 & 193 & 262 & 269 & 66 & 269 & 143 & 235 & 204 & 262 & 270 & 8 & 130 \\
\hline 60 & 277 & 107 & 168 & 195 & 270 & 278 & 67 & 278 & 144 & 242 & 205 & 270 & 278 & 0 & 146 \\
\hline 65 & 276 & 109 & 169 & 196 & 270 & 276 & 66 & 277 & 146 & 242 & 207 & 271 & 277 & 70 & 151 \\
\hline 70 & 267 & 110 & 164 & 196 & 262 & 267 & 66 & 267 & 147 & 235 & 207 & 263 & 268 & 71 & 137 \\
\hline 75 & 270 & 111 & 166 & 195 & 264 & 271 & 65 & 271 & 147 & 238 & 204 & 264 & 271 & 71 & 139 \\
\hline 80 & 279 & 112 & 170 & 197 & 272 & 279 & 64 & 280 & 148 & 244 & 207 & 272 & 280 & 67 & 155 \\
\hline 85 & 275 & 113 & 170 & 198 & 269 & 275 & 65 & 275 & 149 & 242 & 208 & 270 & 276 & 67 & 153 \\
\hline 90 & 265 & 114 & 166 & 198 & 260 & 265 & 65 & 265 & 149 & 235 & 207 & 261 & 266 & 68 & 137 \\
\hline 95 & 272 & 114 & 169 & 196 & 266 & 272 & 66 & 273 & 148 & 239 & 206 & 266 & 273 & 68 & 144 \\
\hline 100 & 280 & 115 & 173 & 197 & 273 & 280 & 67 & 281 & 149 & 245 & 207 & 273 & 281 & 69 & 161 \\
\hline 105 & 274 & 115 & 171 & 199 & 268 & 274 & 67 & 274 & 150 & 241 & 209 & 269 & 275 & 70 & 153 \\
\hline 110 & 264 & 116 & 167 & 196 & 260 & 265 & 67 & 265 & 149 & 234 & 208 & 260 & 265 & 70 & 137 \\
\hline 115 & 273 & 116 & 170 & 196 & 266 & 273 & 66 & 274 & 149 & 240 & 206 & 267 & 274 & 70 & 147 \\
\hline 120 & 279 & 116 & 173 & 198 & 273 & 280 & 65 & 280 & 149 & 245 & 209 & 273 & 280 & 67 & 163 \\
\hline 125 & 273 & 11.6 & 171 & 198 & 268 & 273 & 65 & 274 & 150 & 241 & 209 & 268 & 274 & 67 & 153 \\
\hline 130 & 264 & 116 & 167 & 198 & 260 & 265 & 65 & 265 & 150 & 235 & 207 & 260 & 266 & 68 & 138 \\
\hline 135 & 273 & 116 & 170 & 197 & 267 & 273 & 67 & 274 & 149 & 240 & 206 & 267 & 274 & 70 & 149 \\
\hline 140 & 279 & 117 & 173 & 197 & 273 & 279 & 67 & 280 & 150 & 245 & 208 & 273 & 280 & 70 & 164 \\
\hline 145 & 273 & 117 & 171 & 198 & 268 & 273 & 65 & 273 & 150 & 241 & 209 & 268 & 274 & 69 & 154 \\
\hline 150 & 264 & 117 & 168 & 197 & 260 & 265 & 66 & 265 & 150 & 234 & 207 & 260 & 266 & 67 & 139 \\
\hline 155 & 273 & 117 & 169 & 197 & 266 & 273 & 65 & 273 & 150 & 240 & 206 & 267 & 274 & 68 & 149 \\
\hline 160 & 279 & 117 & 173 & 198 & 273 & 280 & 66 & 280 & 150 & 245 & 208 & 273 & 280 & 69 & 165 \\
\hline 165 & 273 & 117 & 171 & 199 & 268 & 273 & 68 & 273 & 151 & 241 & 209 & 268 & 274 & 70 & 155 \\
\hline 170 & 264 & 117 & 168 & 197 & 260 & 265 & 67 & 265 & 150 & 235 & 208 & 260 & 266 & 70 & 140 \\
\hline 175 & 273 & 117 & 171 & 195 & 266 & 273 & 67 & 273 & 150 & 240 & 206 & 267 & 274 & 70 & 149 \\
\hline 180 & 279 & 117 & 174 & 198 & 273 & 280 & 66 & 280 & 150 & 245 & 208 & 273 & 280 & 68 & 165 \\
\hline 185 & 273 & 117 & 172 & 198 & 268 & 274 & 66 & 274 & 151 & 241 & 209 & 268 & 274 & 68 & 155 \\
\hline
\end{tabular}

rms/WRI 92 


\section{Table 2 : Flowloop Run \#2 (cont.)}

Test Conditions:

Vertical Test Section - no insulation - with vacuum - no coupling insulation

Horizontal Test Section - with insulation - with vacuum - no coupling insulation

Time TC1 TC2 TC3 TC4 TC5 TC6 TC7 TC8 TC9 TC10 TC11 TC12 TC13 TC14 Cond

\begin{tabular}{lllllllllllllllll}
\hline 190 & 264 & 118 & 168 & 198 & 260 & 265 & 66 & 265 & 151 & 235 & 207 & 260 & 266 & 68 & 140 \\
195 & 273 & 118 & 171 & 197 & 267 & 273 & 67 & 274 & 150 & 240 & 206 & 267 & 274 & 69 & 150 \\
200 & 279 & 118 & 174 & 197 & 273 & 280 & 68 & 280 & 150 & 245 & 208 & 273 & 280 & 70 & 165 \\
205 & 273 & 118 & 172 & 198 & 268 & 273 & 69 & 274 & 151 & 241 & 209 & 268 & 274 & 70 & 155 \\
210 & 265 & 118 & 168 & 197 & 260 & 265 & 68 & 265 & 150 & 235 & 207 & 260 & 266 & 70 & 140 \\
215 & 273 & 118 & 171 & 197 & 267 & 274 & 67 & 274 & 150 & 241 & 207 & 267 & 275 & 70 & 151 \\
220 & 278 & 118 & 174 & 198 & 273 & 279 & 66 & 279 & 150 & 245 & 207 & 273 & 280 & 69 & 165 \\
225 & 273 & 118 & 172 & 198 & 267 & 273 & 66 & 273 & 151 & 241 & 208 & 268 & 274 & 69 & 154 \\
230 & 264 & 118 & 168 & 198 & 260 & 265 & 66 & 265 & 151 & 234 & 206 & 260 & 266 & 70 & 140 \\
235 & 273 & 118 & 171 & 197 & 267 & 273 & 66 & 273 & 150 & 240 & 206 & 267 & 274 & 70 & 149 \\
240 & 279 & 118 & 174 & 198 & 273 & 280 & 67 & 280 & 150 & 245 & 207 & 273 & 280 & 70 & 166 \\
245 & 273 & 118 & 172 & 199 & 268 & 273 & 68 & 274 & 151 & 241 & 210 & 268 & 274 & 71 & 155 \\
250 & 264 & 118 & 168 & 197 & 260 & 265 & 69 & 265 & 151 & 235 & 209 & 261 & 266 & 70 & 142 \\
255 & 271 & 118 & 171 & 196 & 265 & 272 & 67 & 272 & 150 & 239 & 206 & 265 & 273 & 70 & 147 \\
260 & 280 & 118 & 174 & 197 & 273 & 280 & 66 & 281 & 150 & 246 & 207 & 273 & 281 & 70 & 165 \\
265 & 274 & 118 & 172 & 198 & 269 & 274 & 66 & 275 & 151 & 242 & 209 & 269 & 275 & 70 & 157 \\
270 & 267 & 118 & 170 & 198 & 262 & 268 & 67 & 268 & 151 & 237 & 207 & 263 & 268 & 69 & 146 \\
275 & 268 & 118 & 170 & 197 & 263 & 269 & 66 & 269 & 150 & 237 & 205 & 263 & 270 & 69 & 143 \\
280 & 200 & 118 & 171 & 197 & 255 & 201 & 66 & 259 & 150 & 179 & 205 & 256 & 213 & 71 & 147
\end{tabular}

$\mathrm{rms} / \mathrm{WRI} 92$ 


\section{Table 3 : Flowloop Run \#3}

Test Conditions:

Vertical Test Section - with insulation - with vacuum - no coupling insulation

Horizontal Test Section - no insulation - with vacuum - no coupling insulation

Time TC1 TC2 TC3 TC4 TC5 TC6 TC7 TC8 TC9 TC10 TC11 TC12 TC13 TC14 Cond

\begin{tabular}{|c|c|c|c|c|c|c|c|c|c|c|c|c|c|c|c|}
\hline 0 & 59 & 59 & 59 & 59 & 59 & 59 & 57 & 63 & 61 & 62 & 61 & 58 & 60 & 61 & 61 \\
\hline 5 & 59 & 59 & 59 & 59 & 59 & 59 & 57 & 63 & 61 & 62 & 61 & 58 & 60 & 61 & 61 \\
\hline 10 & 61 & 59 & 59 & 59 & 60 & 56 & 57 & 125 & 61 & 62 & 61 & 59 & 67 & 62 & 59 \\
\hline 15 & 255 & 70 & 213 & 93 & 254 & 255 & 57 & 255 & 64 & 196 & 98 & 59 & 255 & 233 & 54 \\
\hline 20 & 264 & 82 & 223 & 127 & 264 & 264 & 61 & 264 & 68 & 203 & 132 & 61 & 265 & 247 & 111 \\
\hline 25 & 273 & 93 & 232 & 139 & 273 & 273 & 60 & 273 & 72 & 211 & 152 & 61 & 273 & 259 & 129 \\
\hline 30 & 281 & 105 & 240 & 138 & 281 & 280 & 60 & 281 & 76 & 217 & 166 & 60 & 281 & 269 & 151 \\
\hline 35 & 274 & 114 & 237 & 142 & 275 & 274 & 62 & 274 & 81 & 216 & 175 & 62 & 274 & 266 & 146 \\
\hline 40 & 268 & 121 & 233 & 139 & 268 & 268 & 60 & 268 & 85 & 215 & 180 & 61 & 268 & 261 & 136 \\
\hline 45 & 272 & 127 & 237 & 138 & 272 & 272 & 62 & 272 & 89 & 219 & 183 & 62 & 272 & 265 & 141 \\
\hline 50 & 280 & 133 & 244 & 139 & 280 & 280 & 60 & 280 & 94 & 225 & 186 & 62 & 280 & 272 & 160 \\
\hline 55 & 274 & 137 & 242 & 139 & 275 & 275 & 62 & 275 & 98 & 224 & 190 & 62 & 275 & 268 & 156 \\
\hline 60 & 265 & 140 & 234 & 136 & 266 & 265 & 63 & 266 & 100 & 218 & 191 & 63 & 266 & 259 & 138 \\
\hline 65 & 271 & 142 & 240 & 138 & 272 & 272 & 62 & 272 & 103 & 223 & 191 & 62 & 272 & 264 & 147 \\
\hline 70 & 280 & 143 & 246 & 135 & 280 & 280 & 66 & 280 & 105 & 229 & 191 & 64 & 280 & 271 & 168 \\
\hline 75 & 274 & 145 & 243 & 138 & 275 & 274 & 63 & 275 & 107 & 227 & 194 & 63 & 275 & 268 & 163 \\
\hline 80 & 265 & 146 & 236 & 139 & 266 & 265 & 64 & 265 & 108 & 220 & 194 & 63 & 266 & 259 & 144 \\
\hline 85 & 272 & 147 & 241 & 139 & 272 & 272 & 65 & 272 & 110 & 225 & 193 & 63 & 273 & 264 & 154 \\
\hline 90 & 280 & 148 & 247 & 136 & 280 & 280 & 63 & 281 & 111 & 231 & 194 & 64 & 281 & 271 & 175 \\
\hline 95 & 274 & 148 & 243 & 137 & 275 & 274 & 63 & 274 & 112 & 228 & 195 & 63 & 275 & 267 & 166 \\
\hline 100 & 265 & 148 & 236 & 136 & 265 & 265 & 64 & 265 & 112 & 221 & 194 & 63 & 266 & 259 & 146 \\
\hline 105 & 273 & 148 & 242 & 139 & 273 & 273 & 64 & 274 & 113 & 227 & 193 & 64 & 274 & 265 & 161 \\
\hline 110 & 280 & 149 & 247 & 135 & 280 & 280 & 64 & 280 & 113 & 232 & 194 & 64 & 280 & 271 & 189 \\
\hline 115 & 273 & 150 & 242 & 137 & 273 & 273 & 64 & 273 & 114 & 228 & 195 & 64 & 273 & 266 & 166 \\
\hline 120 & 265 & 149 & 236 & 137 & 266 & 266 & 64 & 266 & 114 & 222 & 194 & 63 & 266 & 259 & 148 \\
\hline 125 & 274 & 149 & 243 & 136 & 274 & 274 & 64 & 275 & 115 & 228 & 193 & 63 & 275 & 266 & 165 \\
\hline 130 & 279 & 150 & 247 & 134 & 279 & 279 & 66 & 279 & 115 & 232 & 195 & 65 & 280 & 271 & 188 \\
\hline 135 & 273 & 150 & 242 & 134 & 273 & 273 & 65 & 273 & 115 & 228 & 196 & 65 & 273 & 266 & 159 \\
\hline 140 & 266 & 150 & 236 & 135 & 266 & 266 & 64 & 266 & 116 & 222 & 195 & 64 & 267 & 260 & 144 \\
\hline 145 & 274 & 150 & 243 & 135 & 275 & 275 & 64 & 275 & 115 & 229 & 194 & 64 & 275 & 267 & 157 \\
\hline 150 & 278 & 150 & 246 & 135 & 279 & 279 & 64 & 279 & 116 & 232 & 195 & 64 & 279 & 271 & 170 \\
\hline 155 & 272 & 150 & 242 & 136 & 273 & 273 & 65 & 273 & 116 & 228 & 196 & 64 & 273 & 266 & 158 \\
\hline 160 & 265 & 149 & 236 & 136 & 266 & 266 & 67 & 266 & 116 & 222 & 195 & 65 & 266 & 259 & 143 \\
\hline 165 & 274 & 149 & 243 & 136 & 275 & 274 & 66 & 275 & 116 & 228 & 194 & 65 & 275 & 267 & 156 \\
\hline 170 & 279 & 150 & 247 & 135 & 279 & 279 & 66 & 279 & 117 & 232 & 195 & 64 & 280 & 272 & 170 \\
\hline 175 & 272 & 150 & 242 & 135 & 273 & 273 & 65 & 273 & 117 & 228 & 196 & 65 & 273 & 266 & 157 \\
\hline 180 & 265 & 149 & 236 & 136 & 265 & 265 & 65 & 266 & 117 & 222 & 195 & 64 & 266 & 259 & 143 \\
\hline 185 & 274 & 149 & 242 & 134 & 274 & 274 & 65 & 274 & 117 & 228 & 194 & 64 & 275 & 267 & \\
\hline
\end{tabular}

rms/WRI 92 
Table 3 : Flowloop Run \#3 (cont.)

Test Conditions:

Vertical Test Section - with insulation - with vacuum - no coupling insulation

Horizontal Test Section - no insulation - with vacuum - no coupling insulation

Time TC1 TC2 TC3 TC4 TC5 TC6 TC7 TC8 TC9 TC10 TC11 TC12 TC13 TC14 Cond

\begin{tabular}{|c|c|c|c|c|c|c|c|c|c|c|c|c|c|c|c|}
\hline 190 & 279 & 150 & 247 & 136 & 280 & 279 & 65 & 280 & $\overline{117}$ & 233 & $\overline{195}$ & 66 & 280 & 272 & 169 \\
\hline 195 & 273 & 150 & 242 & 138 & 273 & 273 & 65 & 273 & 117 & 229 & 196 & 65 & 274 & 266 & 159 \\
\hline 200 & 265 & 149 & 236 & 136 & 266 & 266 & 66 & 266 & 117 & 223 & 194 & 65 & 266 & 259 & 144 \\
\hline 205 & 274 & 149 & 242 & 134 & 274 & 274 & 65 & 274 & 117 & 229 & 194 & 65 & 275 & 267 & 156 \\
\hline 210 & 279 & 149 & 247 & 134 & 279 & 279 & 65 & 279 & 118 & 233 & 196 & 65 & 280 & 271 & 170 \\
\hline 215 & 272 & 150 & 242 & 135 & 273 & 273 & 66 & 273 & 117 & 228 & 196 & 65 & 273 & 266 & 159 \\
\hline 220 & 266 & 149 & 236 & 136 & 266 & 266 & 65 & 266 & 118 & 223 & 195 & 65 & 267 & 259 & 144 \\
\hline 225 & 274 & 149 & 243 & 137 & 275 & 275 & 65 & 275 & 118 & 229 & 194 & 65 & 275 & 267 & 158 \\
\hline 230 & 278 & 150 & 246 & 136 & 279 & 279 & 66 & 279 & 118 & 233 & 195 & 66 & 279 & 272 & 170 \\
\hline 235 & 272 & 150 & 242 & 139 & 273 & 272 & 65 & 273 & 118 & 228 & 196 & 65 & 273 & 265 & 159 \\
\hline 240 & 266 & 150 & 236 & 130 & 266 & 266 & 62 & 266 & 117 & 223 & 194 & 63 & 267 & 259 & 144 \\
\hline 245 & 275 & 149 & 243 & 136 & 275 & 275 & 65 & 275 & 116 & 229 & 194 & 66 & 275 & 267 & 158 \\
\hline 250 & 278 & 150 & 246 & 153 & 279 & 278 & 65 & 279 & 117 & 232 & 195 & 66 & 279 & 271 & 170 \\
\hline 255 & 272 & 150 & 241 & 198 & 273 & 272 & 66 & 272 & 117 & 228 & 196 & 66 & 273 & 266 & 158 \\
\hline 260 & 266 & 150 & 237 & 197 & 267 & 266 & 65 & 267 & 118 & 223 & 194 & 66 & 267 & 260 & 145 \\
\hline 265 & 275 & 150 & 243 & 195 & 275 & 275 & 67 & 275 & 118 & 229 & 193 & 66 & 276 & 267 & 159 \\
\hline 270 & 278 & 150 & 246 & 196 & 279 & 278 & 67 & 279 & 118 & 232 & 195 & 66 & 279 & 271 & 170 \\
\hline 275 & 271 & 150 & 241 & 196 & 272 & 272 & 67 & 272 & 118 & 228 & 196 & 67 & 272 & 6 & 158 \\
\hline 280 & 267 & 150 & 238 & 195 & 268 & 268 & 66 & 268 & 118 & 224 & 194 & 66 & 268 & 261 & 146 \\
\hline 285 & 276 & 150 & 244 & 195 & 276 & 276 & 67 & 277 & 118 & 230 & 193 & 66 & 277 & 269 & 162 \\
\hline 290 & 277 & 150 & 245 & 196 & 278 & 277 & 66 & 278 & 119 & 232 & 195 & 66 & 278 & 271 & 170 \\
\hline 295 & 270 & 150 & 240 & 196 & 271 & 270 & 67 & 271 & 119 & 227 & 196 & 67 & 271 & 264 & 157 \\
\hline 300 & 269 & 150 & 238 & 194 & 269 & 269 & 68 & 269 & 118 & 225 & 194 & 66 & 270 & 261 & 149 \\
\hline $305^{\circ}$ & 278 & 150 & 246 & 194 & 278 & 278 & 66 & 279 & 119 & 232 & 193 & 67 & 279 & 270 & 167 \\
\hline 310 & 275 & 150 & 244 & 196 & 276 & 276 & 68 & 276 & 119 & 231 & 196 & 68 & 276 & 268 & 168 \\
\hline 315 & 269 & 150 & 239 & 195 & 270 & 269 & 67 & 269 & 119 & 226 & 195 & 67 & 270 & 262 & 156 \\
\hline 320 & 270 & 150 & 239 & 194 & 270 & 270 & 66 & 271 & 119 & 226 & 194 & 67 & 271 & 262 & 152 \\
\hline 325 & 280 & 150 & 247 & 194 & 281 & 280 & 66 & 281 & 119 & 233 & 194 & 67 & 281 & 272 & 172 \\
\hline 330 & 274 & 150 & 243 & 195 & 275 & 274 & 67 & 274 & 119 & 230 & 195 & 68 & 275 & 267 & 165 \\
\hline 335 & 268 & 150 & 238 & 195 & 269 & 268 & 67 & 269 & 119 & 225 & 196 & 66 & 269 & 262 & 153 \\
\hline 340 & 269 & 150 & 239 & 193 & 269 & 269 & 65 & 270 & 118 & 225 & 193 & 65 & 270 & 261 & 150 \\
\hline 345 & 278 & 150 & 246 & 194 & 279 & 279 & 67 & 279 & 118 & 232 & 194 & 66 & 279 & 270 & 167 \\
\hline 350 & 275 & 150 & 244 & 195 & 276 & 275 & 66 & 276 & 118 & 230 & 195 & 67 & 276 & 268 & 167 \\
\hline 355 & 269 & 150 & 239 & 195 & 270 & 270 & 66 & 270 & 119 & 226 & 195 & 67 & 270 & 263 & 155 \\
\hline 360 & 265 & 150 & 235 & 193 & 265 & 265 & 67 & 265 & 118 & 222 & 194 & 67 & 266 & 258 & 145 \\
\hline 365 & 273 & 149 & 242 & 192 & 274 & 274 & 66 & 274 & 119 & 228 & 193 & 67 & 275 & 266 & 159 \\
\hline 370 & 279 & 150 & 247 & 194 & 279 & 279 & 67 & 279 & 119 & 233 & 194 & 67 & 280 & 271 & 174 \\
\hline 375 & 272 & 150 & 242 & 195 & 273 & 273 & 67 & 273 & 119 & 229 & 195 & 67 & 273 & 266 & 162 \\
\hline
\end{tabular}

rms/WRI 92 
Table 4 : Flowloop Run \#4

Test Conditions:

Vertical Test Section - with insulation - no vacuum - no coupling insulation

Horizontal Tesi Soction - no insulation - no vacuum - no coupling insulation

Time TC1 TC2 TC3 TC4 TC5 TC6 TC7 TC8 TC9 TC10 TC11 TC12 TC13 TC14 Cond

\begin{tabular}{|c|c|c|c|c|c|c|c|c|c|c|c|c|c|c|c|}
\hline $\begin{array}{l}0 \\
5\end{array}$ & $\begin{array}{c}58 \\
276\end{array}$ & $\begin{array}{l}58 \\
69\end{array}$ & $\begin{array}{c}58 \\
227\end{array}$ & $\begin{array}{l}58 \\
80\end{array}$ & $\begin{array}{c}58 \\
454\end{array}$ & $\begin{array}{c}58 \\
276\end{array}$ & $\begin{array}{l}60 \\
58\end{array}$ & $\begin{array}{l}148 \\
276\end{array}$ & $\begin{array}{l}60 \\
62\end{array}$ & $\begin{array}{c}60 \\
205\end{array}$ & $\begin{array}{l}59 \\
94\end{array}$ & $\begin{array}{c}59 \\
188\end{array}$ & $\begin{array}{c}58 \\
276\end{array}$ & $\begin{array}{l}60 \\
60\end{array}$ & $\begin{array}{l}70 \\
55\end{array}$ \\
\hline 10 & 274 & 88 & 229 & 128 & -454 & 274 & 59 & 274 & 66 & 206 & 133 & 220 & 274 & 61 & 53 \\
\hline 15 & 210 & 100 & 196 & 146 & -454 & 210 & 59 & 254 & 71 & 199 & 147 & 199 & 222 & 61 & 58 \\
\hline 20 & 269 & 111 & 228 & 159 & 262 & 268 & 61 & 269 & 75 & 207 & 158 & 230 & 269 & 62 & 106 \\
\hline 25 & 270 & 120 & 231 & 170 & 264 & 270 & 61 & 270 & 80 & 211 & 169 & 235 & 270 & 61 & 112 \\
\hline 30 & 278 & 128 & 239 & 179 & 272 & 278 & 60 & 279 & 85 & 217 & 176 & 244 & 279 & 62 & 126 \\
\hline 35 & 275 & 136 & 239 & 186 & 270 & 274 & 62 & 275 & 89 & 219 & 183 & 246 & 275 & 62 & 129 \\
\hline 40 & 265 & 141 & 233 & 188 & 261 & 265 & 61 & 266 & 92 & 214 & 186 & 241 & 266 & 61 & 119 \\
\hline 45 & 273 & 144 & 239 & 189 & 268 & 273 & 61 & 274 & 96 & 220 & 187 & 246 & 274 & 61 & 126 \\
\hline 50 & 279 & 148 & 245 & 193 & 275 & 279 & 62 & 280 & 99 & 226 & 189 & 252 & 280 & 62 & 141 \\
\hline 55 & 272 & 151 & 240 & 194 & 268 & 272 & 61 & 272 & 102 & 221 & 192 & 248 & 272 & 62 & 133 \\
\hline 60 & 266 & 152 & 236 & 193 & 262 & 266 & 62 & 267 & 104 & 218 & 191 & 244 & 267 & 63 & 123 \\
\hline 65 & 275 & 153 & 243 & 194 & 270 & 275 & 62 & 276 & 106 & 225 & 190 & 250 & 276 & 63 & 135 \\
\hline 70 & 278 & 155 & 244 & 196 & 274 & 278 & 61 & 278 & 108 & 227 & 192 & 253 & 278 & 63 & 144 \\
\hline 75 & 272 & 156 & 240 & 197 & 268 & 272 & 62 & 272 & 109 & 223 & 194 & 249 & 272 & 64 & 136 \\
\hline 80 & 265 & 155 & 235 & 196 & 261 & 265 & 61 & 266 & 110 & 219 & 193 & 244 & 266 & 63 & 126 \\
\hline 85 & 275 & 156 & 242 & 195 & 270 & 275 & 62 & 275 & 111 & 226 & 192 & 250 & 275 & 64 & 137 \\
\hline $\begin{array}{l}90 \\
95\end{array}$ & $\begin{array}{l}278 \\
272\end{array}$ & $\begin{array}{l}157 \\
158\end{array}$ & $\begin{array}{l}245 \\
241\end{array}$ & $\begin{array}{l}197 \\
197\end{array}$ & $\begin{array}{l}274 \\
268\end{array}$ & $\begin{array}{l}278 \\
273\end{array}$ & $\begin{array}{l}61 \\
64\end{array}$ & $\begin{array}{l}279 \\
273\end{array}$ & $\begin{array}{l}112 \\
112\end{array}$ & $\begin{array}{l}229 \\
225\end{array}$ & $\begin{array}{l}194 \\
195\end{array}$ & $\begin{array}{l}254 \\
251\end{array}$ & $\begin{array}{l}279 \\
273\end{array}$ & $\begin{array}{l}63 \\
64\end{array}$ & $\begin{array}{l}147 \\
139\end{array}$ \\
\hline 100 & 265 & 157 & 236 & 197 & 262 & 265 & 62 & 266 & 113 & 220 & 194 & 245 & 266 & 64 & 129 \\
\hline 105 & 272 & 157 & 241 & 195 & 267 & 272 & 63 & 273 & 113 & 225 & 192 & 249 & 273 & 64 & 134 \\
\hline 110 & 280 & 157 & 247 & 197 & 275 & 280 & 62 & 280 & 114 & 231 & 194 & 255 & 280 & 64 & 149 \\
\hline 115 & 274 & 158 & 243 & 198 & 270 & 274 & 62 & 274 & 114 & 227 & 195 & 252 & 275 & 64 & 143 \\
\hline 120 & 268 & 158 & 238 & 198 & 264 & 268 & 62 & 268 & 114 & 222 & 195 & 248 & 268 & 64 & 134 \\
\hline 125 & 269 & 157 & 238 & 196 & 264 & 269 & 62 & 269 & 114 & 223 & 193 & 246 & 269 & 64 & 131 \\
\hline 130 & 278 & 158 & 245 & 196 & 273 & 278 & 64 & 278 & 114 & 229 & 193 & 253 & 279 & 65 & 144 \\
\hline $\begin{array}{l}135 \\
140\end{array}$ & $\begin{array}{l}276 \\
270\end{array}$ & $\begin{array}{l}158 \\
158\end{array}$ & $\begin{array}{l}244 \\
240\end{array}$ & $\begin{array}{l}198 \\
198\end{array}$ & $\begin{array}{l}272 \\
267\end{array}$ & $\begin{array}{l}276 \\
271\end{array}$ & $\begin{array}{l}62 \\
62\end{array}$ & $\begin{array}{l}277 \\
271\end{array}$ & $\begin{array}{l}114 \\
115\end{array}$ & $\begin{array}{l}229 \\
224\end{array}$ & $\begin{array}{l}195 \\
195\end{array}$ & $\begin{array}{l}253 \\
250\end{array}$ & $\begin{array}{l}277 \\
271\end{array}$ & $\begin{array}{l}64 \\
64\end{array}$ & $\begin{array}{l}147 \\
138\end{array}$ \\
\hline 145 & 265 & 157 & 235 & 197 & 261 & 265 & 63 & 265 & 114 & 220 & 194 & 245 & 266 & 64 & 129 \\
\hline 150 & 274 & 157 & 242 & 195 & 269 & 274 & 63 & 274 & 115 & 227 & 193 & 250 & 275 & 64 & 139 \\
\hline 155 & 279 & 158 & 246 & 198 & 275 & 279 & 62 & 279 & 114 & 231 & 195 & 255 & 279 & 64 & 151 \\
\hline 160 & 273 & 159 & 242 & 199 & 269 & 273 & 64 & 273 & 115 & 226 & 196 & 252 & 274 & 65 & 143 \\
\hline 165 & 265 & 158 & 236 & 198 & 262 & 266 & 63 & 266 & 115 & 221 & 195 & 247 & 266 & 65 & 133 \\
\hline 170 & 271 & 158 & 240 & 196 & 267 & 271 & 62 & 272 & 115 & 225 & 193 & 248 & 272 & 64 & 136 \\
\hline 175 & 280 & 158 & 247 & 198 & 276 & 280 & 62 & 281 & 115 & 231 & 194 & 255 & 281 & 64 & 151 \\
\hline 180 & 275 & 159 & 243 & 199 & 271 & 275 & 63 & 275 & 115 & 228 & 19 & 253 & 275 & 65 & 147 \\
\hline 185 & 268 & 159 & 239 & 199 & 265 & 268 & 63 & 269 & 115 & 223 & & 249 & 269 & 65 & 138 \\
\hline
\end{tabular}

$\mathrm{rms} / \mathrm{WRJ} 92$ 
Table 4 : Flowloop Run \#4 (cont.)

Test Conditions:

Vertical Test Section - with insulation - no vacuum - no coupling insulation

Horizontal Test Section - no insulation - no vacuum - no coupling insulation

Thme TC1 TC2 TC3 TC4 TC5 TC6 TC7 TC8 TC9 TC10 TC11 TC12 TC13 TC14 Cond

\begin{tabular}{|c|c|c|c|c|c|c|c|c|c|c|c|c|c|c|c|}
\hline $\begin{array}{l}190 \\
195\end{array}$ & $\begin{array}{l}269 \\
278\end{array}$ & $\begin{array}{l}158 \\
158\end{array}$ & $\begin{array}{l}238 \\
245\end{array}$ & $\begin{array}{l}197 \\
198\end{array}$ & $\begin{array}{l}264 \\
273\end{array}$ & $\begin{array}{l}269 \\
278\end{array}$ & $\begin{array}{l}63 \\
63\end{array}$ & $\begin{array}{l}269 \\
279\end{array}$ & $\begin{array}{l}115 \\
115\end{array}$ & $\begin{array}{l}223 \\
230\end{array}$ & $\begin{array}{l}194 \\
193\end{array}$ & $\begin{array}{l}247 \\
253\end{array}$ & $\begin{array}{l}270 \\
279\end{array}$ & $\begin{array}{l}65 \\
65\end{array}$ & $\begin{array}{l}134 \\
148\end{array}$ \\
\hline 200 & 276 & 159 & 245 & 200 & 272 & 276 & 63 & 276 & 115 & 229 & 195 & 254 & 277 & 65 & 150 \\
\hline 205 & 270 & 159 & 240 & 200 & 267 & 271 & 63 & 271 & 115 & 225 & 196 & 250 & 271 & 65 & 141 \\
\hline 210 & 267 & 158 & 237 & 197 & 263 & 267 & 64 & 267 & 115 & 222 & 194 & 246 & 268 & 66 & 133 \\
\hline 215 & 276 & 159 & 244 & 198 & 271 & 276 & 63 & 277 & 116 & 229 & 194 & 253 & 277 & 66 & 146 \\
\hline 220 & 277 & 159 & 246 & 198 & 274 & 277 & 61 & 278 & 115 & 230 & 195 & 255 & 278 & 64 & 154 \\
\hline 225 & 272 & 160 & 241 & 199 & 268 & 272 & 63 & 272 & 114 & 226 & 195 & 251 & 273 & 64 & 145 \\
\hline 230 & 265 & 159 & 236 & 198 & 261 & 265 & 62 & 265 & 114 & 220 & 194 & 246 & 265 & 63 & 134 \\
\hline 23 & 274 & 159 & 242 & 196 & 269 & 27 & 61 & 274 & 113 & 227 & 192 & 250 & 275 & & 144 \\
\hline 240 & 279 & 159 & 247 & 197 & 27 & 2 & 6 & 2 & 11 & 231 & 19 & & 280 & & 157 \\
\hline 245 & 273 & 160 & 242 & 198 & 269 & 273 & 62 & 274 & 113 & 227 & 195 & 252 & 274 & 63 & 149 \\
\hline 250 & 267 & 159 & 237 & 197 & 263 & 267 & 62 & 267 & 114 & 222 & 194 & 248 & 268 & 3 & 140 \\
\hline 255 & 270 & 158 & 239 & 195 & 265 & 270 & 61 & 270 & 114 & 224 & 193 & 248 & 271 & J & 139 \\
\hline 260 & 279 & 159 & 246 & 197 & 274 & 279 & 62 & 280 & 113 & 231 & 193 & 254 & 280 & 63 & 154 \\
\hline 265 & 275 & 159 & 244 & 199 & 271 & 275 & 62 & 276 & 113 & 228 & 195 & 253 & 276 & 63 & 153 \\
\hline 270 & 270 & 160 & 240 & 199 & 266 & 270 & 62 & 270 & 113 & 224 & 194 & 249 & 270 & 03 & 144 \\
\hline 275 & 267 & 159 & 238 & 197 & 263 & 267 & 63 & 268 & 112 & 222 & 193 & 246 & 268 & 64 & 137 \\
\hline $\begin{array}{l}280 \\
285\end{array}$ & $\begin{array}{l}276 \\
277\end{array}$ & $\begin{array}{l}159 \\
160\end{array}$ & $\begin{array}{l}244 \\
246\end{array}$ & $\begin{array}{l}197 \\
199\end{array}$ & $\begin{array}{l}272 \\
273\end{array}$ & $\begin{array}{l}276 \\
277\end{array}$ & $\begin{array}{l}63 \\
63\end{array}$ & $\begin{array}{l}277 \\
278\end{array}$ & $\begin{array}{l}111 \\
111\end{array}$ & $\begin{array}{l}228 \\
229\end{array}$ & $\begin{array}{l}193 \\
194\end{array}$ & $\begin{array}{l}252 \\
254\end{array}$ & $\begin{array}{l}277 \\
278\end{array}$ & & $\begin{array}{l}150 \\
158\end{array}$ \\
\hline 290 & 271 & 160 & 241 & 200 & 268 & 271 & 63 & 272 & 111 & 225 & 195 & 250 & 272 & 64 & 148 \\
\hline 295 & 265 & 159 & 236 & 198 & 261 & 265 & 63 & 266 & 111 & 220 & 193 & 245 & 266 & os & 138 \\
\hline 300 & 274 & 159 & 243 & 197 & 270 & 274 & 62 & 275 & 111 & 227 & 192 & 250 & 275 & 63 & 148 \\
\hline 305 & 278 & 160 & 247 & 199 & 275 & 278 & 62 & 279 & 112 & 230 & 194 & 255 & 279 & 03 & 161 \\
\hline 310 & 273 & 160 & 242 & 199 & 269 & 273 & 63 & 273 & 112 & 226 & 194 & 251 & 273 & 64 & 152 \\
\hline 315 & 265 & 160 & 237 & 197 & 262 & 265 & 62 & 266 & 112 & 220 & 194 & 246 & 266 & 64 & 141 \\
\hline 320 & 271 & 159 & 241 & 197 & 267 & 271 & 63 & 272 & 112 & 225 & 192 & 249 & 272 & 64 & 145 \\
\hline $\begin{array}{l}325 \\
330\end{array}$ & $\begin{array}{l}280 \\
275\end{array}$ & $\begin{array}{l}160 \\
160\end{array}$ & $\begin{array}{l}248 \\
244\end{array}$ & $\begin{array}{l}198 \\
199\end{array}$ & $\begin{array}{l}276 \\
271\end{array}$ & $\begin{array}{l}28 \\
27\end{array}$ & $\begin{array}{l}62 \\
63\end{array}$ & & & & & & & 6 & $\begin{array}{l}161 \\
156\end{array}$ \\
\hline 335 & 269 & 160 & 239 & 199 & 266 & 269 & 63 & 270 & 113 & 223 & 194 & 249 & 270 & 64 & 147 \\
\hline 340 & 268 & 159 & 238 & 197 & 263 & 268 & 63 & 268 & 113 & 222 & 193 & 246 & 268 & 64 & 140 \\
\hline 345 & 277 & 159 & 245 & 197 & 272 & 277 & 62 & 277 & 113 & 229 & 193 & 252 & 278 & 64 & 153 \\
\hline 350 & 277 & 160 & 245 & 200 & 273 & 277 & 63 & 277 & 113 & 229 & 194 & 254 & 278 & 64 & 159 \\
\hline 355 & 271 & 160 & 241 & 200 & 268 & 271 & 63 & 272 & 112 & 225 & 195 & 251 & 272 & 64 & 150 \\
\hline 360 & 265 & 159 & 236 & 198 & 261 & 265 & 63 & 265 & 112 & 220 & 194 & 246 & 266 & 64 & 139 \\
\hline 365 & 274 & 159 & 243 & 198 & 270 & 274 & 63 & 275 & 113 & 227 & 193 & 250 & 275 & 64 & 149 \\
\hline 370 & 279 & 160 & 247 & 198 & 275 & 279 & 63 & 279 & 113 & 231 & 194 & 255 & 280 & 64 & 162 \\
\hline 37 & 273 & 160 & 243 & 200 & 26 & 273 & 64 & 274 & 113 & 226 & 195 & 252 & 274 & 6 & 153 \\
\hline 38 & 266 & 160 & 237 & 199 & 263 & 266 & 63 & 267 & 112 & 221 & 194 & 247 & 267 & 65 & 143 \\
\hline 38 & 271 & 159 & 240 & 197 & 266 & 271 & 63 & 271 & 112 & 224 & 192 & 248 & 271 & 65 & 144 \\
\hline 39 & 280 & 159 & 247 & 198 & 275 & 280 & 63 & 280 & 112 & 231 & 193 & 255 & 281 & 65 & 160 \\
\hline 39 & 200 & 157 & 210 & 194 & 230 & 200 & 64 & 265 & 112 & 219 & 191 & 235 & 249 & 65 & 138 \\
\hline
\end{tabular}

rms/WRI 92 
Table 5 : Flowloop Run \#5

Test Conditions:

Vertical Test Section - with insulation - no vacuum - no coupling insulation

Horizontal Test Section - with insulation - no vacuum - with coupling insulation

Time TC1 TC2 TC3 TC4 TC5 TC6 TC7 TC8 TC9 TC10 TC11 TC12 TC13 TC14 Cond

\begin{tabular}{|c|c|c|c|c|c|c|c|c|c|c|c|c|c|c|c|}
\hline 0 & $\overline{213}$ & $\overline{58}$ & $\overline{146}$ & $\overline{58}$ & $\overline{123}$ & 213 & $\overline{58}$ & 215 & $\overline{80}$ & $\overline{164}$ & 79 & $\overline{134}$ & 216 & 60 & 67 \\
\hline 5 & 270 & 62 & 214 & 93 & 251 & 270 & 59 & 270 & 82 & 209 & 120 & 215 & 270 & 60 & 115 \\
\hline $\begin{array}{l}10 \\
15\end{array}$ & $\begin{array}{l}267 \\
275\end{array}$ & $\begin{array}{l}67 \\
72\end{array}$ & $\begin{array}{l}213 \\
220\end{array}$ & $\begin{array}{l}129 \\
150\end{array}$ & $\begin{array}{l}252 \\
262\end{array}$ & $\begin{array}{l}267 \\
275\end{array}$ & $\begin{array}{l}59 \\
61\end{array}$ & $\begin{array}{l}267 \\
275\end{array}$ & $\begin{array}{l}85 \\
88\end{array}$ & 209 & $\begin{array}{l}147 \\
163\end{array}$ & $\begin{array}{l}224 \\
236\end{array}$ & $\begin{array}{l}267 \\
275\end{array}$ & $\begin{array}{l}61 \\
62\end{array}$ & $\begin{array}{l}118 \\
134\end{array}$ \\
\hline 20 & 278 & 78 & 224 & 166 & 268 & 278 & 60 & 278 & 90 & 219 & 174 & 244 & 278 & 61 & 149 \\
\hline 25 & 269 & 83 & 218 & 176 & 261 & 268 & 60 & 269 & 94 & 216 & 180 & 241 & 269 & 62 & 137 \\
\hline 30 & 269 & 88 & 219 & 180 & 260 & 269 & 61 & 270 & 96 & 217 & 183 & 242 & 270 & 62 & 135 \\
\hline 35 & 278 & 93 & 227 & 184 & 268 & 277 & 60 & 278 & 99 & 224 & 186 & 249 & 278 & 62 & 152 \\
\hline 40 & 276 & 97 & 227 & 188 & 268 & 276 & 61 & 276 & 102 & 224 & 190 & 250 & 276 & 63 & 157 \\
\hline 45 & 266 & 101 & 220 & 190 & 260 & 266 & 62 & 266 & 104 & 218 & 190 & 245 & 266 & 63 & 141 \\
\hline 50 & 272 & 104 & 225 & 190 & 264 & 272 & 61 & 272 & 106 & 222 & 190 & 247 & 272 & 64 & 147 \\
\hline $\begin{array}{l}55 \\
60\end{array}$ & $\begin{array}{l}280 \\
274\end{array}$ & $\begin{array}{l}107 \\
109\end{array}$ & $\begin{array}{l}233 \\
228\end{array}$ & $\begin{array}{l}191 \\
194\end{array}$ & $\begin{array}{l}271 \\
267\end{array}$ & $\begin{array}{l}280 \\
274\end{array}$ & $\begin{array}{l}64 \\
61\end{array}$ & $\begin{array}{l}280 \\
274\end{array}$ & $\begin{array}{l}107 \\
109\end{array}$ & $\begin{array}{l}228 \\
225\end{array}$ & $\begin{array}{l}193 \\
194\end{array}$ & $\begin{array}{l}253 \\
251\end{array}$ & $\begin{array}{l}280 \\
274\end{array}$ & $\begin{array}{l}64 \\
64\end{array}$ & $\begin{array}{l}165 \\
158\end{array}$ \\
\hline 65 & 266 & 111 & 222 & 193 & 259 & 266 & 63 & 266 & 110 & 218 & 195 & 245 & 266 & 64 & 141 \\
\hline 70 & 274 & 112 & 229 & 193 & 266 & 274 & 61 & 274 & 111 & 225 & 193 & 250 & 275 & 64 & 155 \\
\hline 75 & 279 & 114 & 233 & 194 & 271 & 278 & 63 & 279 & 112 & 229 & 193 & 254 & 279 & 64 & 168 \\
\hline 80 & 271 & 114 & 228 & 195 & 265 & 271 & 62 & 272 & 113 & 224 & 195 & 250 & 272 & 64 & 157 \\
\hline 85 & 267 & 115 & 224 & 195 & 260 & 267 & 61 & 268 & 114 & 221 & 194 & 246 & 268 & 64 & 145 \\
\hline 90 & 276 & 116 & 232 & 194 & 268 & 276 & 62 & 276 & 114 & 228 & 193 & 252 & 277 & 65 & 161 \\
\hline 95 & 277 & 117 & 233 & 196 & 271 & 277 & 62 & 278 & 114 & 229 & 195 & 254 & 278 & 64 & 168 \\
\hline 100 & 270 & 117 & 227 & 197 & 264 & 270 & 62 & 270 & 113 & 22 & 19 & 250 & 270 & 64 & 155 \\
\hline 105 & 268 & 118 & 226 & 195 & 261 & 268 & 6 & 269 & 113 & 222 & 193 & 247 & & & 148 \\
\hline 110 & 277 & 119 & 233 & 195 & 269 & 277 & 62 & 278 & 112 & 229 & 192 & 253 & 278 & 63 & 164 \\
\hline 115 & 276 & 119 & 233 & 196 & 270 & 276 & 61 & 277 & 113 & 228 & 195 & 253 & 277 & 63 & 168 \\
\hline 120 & 269 & 119 & 227 & 197 & 264 & 269 & 62 & 270 & 113 & 223 & 194 & 249 & 270 & 63 & 156 \\
\hline 125 & 268 & 119 & 226 & 196 & 261 & 268 & 62 & 269 & 112 & 222 & 193 & 247 & 269 & 63 & 149 \\
\hline 130 & 277 & 119 & 233 & 195 & 269 & 277 & 62 & 277 & 113 & 228 & 193 & 252 & 278 & 63 & 166 \\
\hline 135 & 277 & 120 & 233 & 197 & 270 & 277 & 63 & 277 & 113 & 229 & 195 & 254 & 277 & 64 & 171 \\
\hline $\begin{array}{l}140 \\
145\end{array}$ & $\begin{array}{l}269 \\
269\end{array}$ & $\begin{array}{l}120 \\
120\end{array}$ & $\begin{array}{l}227 \\
227\end{array}$ & $\begin{array}{l}198 \\
197\end{array}$ & $\begin{array}{l}264 \\
262\end{array}$ & $\begin{array}{l}269 \\
269\end{array}$ & $\begin{array}{l}62 \\
62\end{array}$ & $\begin{array}{l}269 \\
269\end{array}$ & $\begin{array}{l}112 \\
113\end{array}$ & $\begin{array}{l}223 \\
222\end{array}$ & $\begin{array}{l}194 \\
194\end{array}$ & $\begin{array}{l}249 \\
247\end{array}$ & $\begin{array}{l}270 \\
269\end{array}$ & $\begin{array}{l}64 \\
63\end{array}$ & $\begin{array}{l}157 \\
151\end{array}$ \\
\hline 150 & 278 & 120 & 234 & 196 & 270 & 278 & 62 & 278 & 114 & 229 & 194 & 253 & 278 & 64 & 168 \\
\hline 155 & 276 & 120 & 233 & 198 & 270 & 276 & 62 & 276 & 114 & 228 & 195 & 254 & 277 & 64 & 171 \\
\hline 160 & 267 & 120 & 226 & 198 & 262 & 267 & 63 & 267 & 114 & 222 & 195 & 248 & 268 & 64 & 156 \\
\hline 165 & 272 & 120 & 229 & 196 & 264 & 272 & 63 & 272 & 114 & 225 & 194 & 249 & 272 & 64 & 159 \\
\hline 170 & 280 & 120 & 236 & 197 & 272 & 280 & 62 & 280 & 115 & 231 & 195 & 255 & 281 & 65 & 182 \\
\hline 175 & 274 & 120 & 232 & 198 & 268 & 274 & 63 & 275 & 115 & 227 & 196 & 253 & 275 & 65 & 170 \\
\hline 180 & 266 & 120 & 225 & 198 & 261 & 266 & 63 & 266 & 115 & 221 & 196 & 247 & 266 & 65 & 155 \\
\hline 185 & 272 & 120 & 229 & 196 & 265 & 272 & 63 & 272 & 115 & 225 & 194 & 249 & 272 & 65 & 160 \\
\hline
\end{tabular}

rms/WRI 92 


\section{Table 5 : Flowloop Run \#5 (cont.)}

Test Conditions:

Vertical Test Section - with insulation - no vacuum - no coupling insulation

Horizontal Test Section - with insulation - no vacuum - with coupling insulation

Thme TC1 TC2 TC3 TC4 TC5 TC6 TC7 TC8 TC9 TC10 TC11 TC12 TC13 TC14 Cond

\begin{tabular}{|c|c|c|c|c|c|c|c|c|c|c|c|c|c|c|c|}
\hline 190 & $\overline{280}$ & 120 & $\overline{236}$ & $\overline{197}$ & $\overline{272}$ & 280 & $\overline{63}$ & $\overline{280}$ & $\overline{115}$ & $\overline{231}$ & 195 & $\overline{256}$ & $\overline{281}$ & $\overline{65}$ & 187 \\
\hline 195 & 274 & 120 & 231 & 198 & 268 & 274 & 62 & 274 & 115 & 227 & 196 & 253 & 275 & 65 & 170 \\
\hline 200 & 265 & 120 & 224 & 198 & 260 & 265 & 63 & 265 & 115 & 220 & 195 & 247 & 266 & 65 & 53 \\
\hline 2 & 273 & 120 & 230 & 196 & 266 & 273 & 62 & 273 & 114 & 226 & 19 & & 274 & & \\
\hline 210 & 280 & 120 & 236 & 197 & 272 & 280 & 63 & 280 & 114 & 231 & 195 & 256 & 280 & 65 & 86 \\
\hline 215 & 273 & 120 & 231 & 198 & 267 & 273 & 63 & 274 & 114 & 226 & 196 & 252 & 274 & 65 & 168 \\
\hline 220 & 265 & 121 & 224 & 198 & 260 & 265 & 63 & 266 & 114 & 220 & 195 & 246 & 266 & 65 & 151 \\
\hline 225 & 274 & 120 & 231 & 196 & 267 & 274 & 63 & 275 & 114 & 227 & 194 & 251 & 275 & 65 & 164 \\
\hline 230 & 279 & 120 & 235 & 197 & 272 & 279 & 63 & 279 & 114 & 230 & 195 & 255 & 279 & 64 & 186 \\
\hline 235 & 273 & 120 & 230 & 198 & 267 & 273 & 62 & 273 & 114 & 226 & 195 & 252 & 273 & 64 & 167 \\
\hline 240 & 266 & 120 & 224 & 198 & 260 & 266 & 62 & 266 & 115 & 220 & 195 & 246 & 267 & 64 & 152 \\
\hline $\begin{array}{l}245 \\
250\end{array}$ & $\begin{array}{l}274 \\
279\end{array}$ & $\begin{array}{l}120 \\
120\end{array}$ & $\begin{array}{l}231 \\
235\end{array}$ & $\begin{array}{l}196 \\
197\end{array}$ & $\begin{array}{l}267 \\
272\end{array}$ & $\begin{array}{l}274 \\
279\end{array}$ & $\begin{array}{l}62 \\
63\end{array}$ & $\begin{array}{l}275 \\
279\end{array}$ & $\begin{array}{l}115 \\
115\end{array}$ & $\begin{array}{l}227 \\
230\end{array}$ & $\begin{array}{l}194 \\
195\end{array}$ & $\begin{array}{l}251 \\
256\end{array}$ & $\begin{array}{l}275 \\
279\end{array}$ & $\begin{array}{l}64 \\
64\end{array}$ & $\begin{array}{l}166 \\
189\end{array}$ \\
\hline 255 & 272 & 120 & 230 & 198 & 266 & 272 & 63 & 272 & 115 & 225 & 19 & 252 & 272 & 64 & 167 \\
\hline 260 & 267 & 120 & 225 & 197 & 261 & 267 & 62 & 267 & 115 & 221 & 194 & 247 & 268 & 6 & 154 \\
\hline 265 & 276 & 120 & 233 & 196 & 268 & 276 & 62 & 276 & 115 & 228 & 194 & 252 & 277 & 64 & 169 \\
\hline 270 & 277 & 120 & 234 & 198 & 271 & 277 & 63 & 278 & 115 & 230 & 195 & 255 & 278 & 04 & 183 \\
\hline 275 & 271 & 120 & 229 & 198 & 265 & 271 & 63 & 271 & 115 & 224 & 196 & 251 & 271 & 4 & 166 \\
\hline 280 & 268 & 120 & 226 & 197 & 261 & 268 & 62 & 268 & 115 & 222 & 195 & 247 & 269 & 64 & 155 \\
\hline 285 & 277 & 119 & 233 & 196 & 269 & 277 & 62 & 277 & 116 & 229 & 194 & 253 & 278 & 34 & 172 \\
\hline $\begin{array}{l}290 \\
295\end{array}$ & $\begin{array}{l}277 \\
270\end{array}$ & $\begin{array}{l}120 \\
120\end{array}$ & $\begin{array}{l}234 \\
228\end{array}$ & $\begin{array}{l}198 \\
199\end{array}$ & $\begin{array}{l}271 \\
265\end{array}$ & $\begin{array}{l}277 \\
270\end{array}$ & $\begin{array}{l}63 \\
63\end{array}$ & $\begin{array}{l}277 \\
270\end{array}$ & $\begin{array}{l}115 \\
115\end{array}$ & $\begin{array}{l}229 \\
224\end{array}$ & $\begin{array}{l}19 \\
19\end{array}$ & $\begin{array}{l}255 \\
251\end{array}$ & $\begin{array}{l}277 \\
271\end{array}$ & & $\begin{array}{l}180 \\
165\end{array}$ \\
\hline 300 & 268 & 120 & 226 & 197 & 262 & 268 & 63 & 268 & 11 & 222 & 194 & 247 & 269 & 65 & 155 \\
\hline 305 & 277 & 120 & 234 & 197 & 269 & 277 & 63 & 277 & 115 & 229 & 194 & 253 & 278 & 65 & 172 \\
\hline 310 & 277 & 120 & 234 & 198 & 271 & 277 & 62 & 277 & 115 & 229 & 196 & 254 & 277 & 65 & 182 \\
\hline 315 & 269 & 120 & 227 & 199 & 264 & 269 & 62 & 269 & 11 & 223 & 196 & 250 & 270 & 65 & 16 \\
\hline 320 & 270 & 120 & 227 & 197 & 263 & 270 & 63 & 270 & 11 & 223 & 194 & 248 & 270 & 64 & 15 \\
\hline 325 & 278 & 120 & 235 & 197 & 271 & 278 & 62 & 279 & 11 & 230 & 194 & 254 & 279 & 65 & 178 \\
\hline $\begin{array}{l}330 \\
335\end{array}$ & $\begin{array}{l}276 \\
267\end{array}$ & $\begin{array}{l}120 \\
120\end{array}$ & $\begin{array}{l}233 \\
226\end{array}$ & $\begin{array}{l}198 \\
198\end{array}$ & $\begin{array}{l}270 \\
262\end{array}$ & $\begin{array}{l}276 \\
268\end{array}$ & $\begin{array}{l}63 \\
63\end{array}$ & $\begin{array}{l}276 \\
268\end{array}$ & $\begin{array}{l}115 \\
116\end{array}$ & $\begin{array}{l}228 \\
222\end{array}$ & $\begin{array}{l}196 \\
196\end{array}$ & $\begin{array}{l}254 \\
249\end{array}$ & $\begin{array}{l}276 \\
268\end{array}$ & & $\begin{array}{l}179 \\
161\end{array}$ \\
\hline 340 & 271 & 120 & 228 & 197 & 264 & 271 & 63 & 271 & 116 & 224 & 194 & 249 & 271 & 65 & 162 \\
\hline 345 & 279 & 120 & 235 & 197 & 272 & 279 & 62 & 280 & 116 & 231 & 195 & 255 & 280 & 65 & $19 ?$ \\
\hline 350 & 275 & 120 & 232 & 199 & 269 & 275 & 62 & 275 & 116 & 228 & 196 & 253 & 275 & 65 & 177 \\
\hline 355 & 266 & 120 & 225 & 198 & 261 & 267 & 63 & 267 & 116 & 222 & 196 & 248 & 267 & 66 & 160 \\
\hline 360 & 272 & 120 & 229 & 197 & 265 & 272 & 63 & 272 & 116 & 225 & 194 & 249 & 272 & 65 & 16 \\
\hline 365 & 280 & 120 & 236 & 197 & 272 & 280 & 66 & 281 & 115 & 231 & 195 & 256 & 281 & 67 & 19 \\
\hline 370 & 275 & 120 & 232 & 199 & 269 & 275 & 63 & 275 & 116 & 228 & 197 & 253 & 275 & 66 & 177 \\
\hline $\begin{array}{l}375 \\
380\end{array}$ & $\begin{array}{l}267 \\
271\end{array}$ & $\begin{array}{l}120 \\
120\end{array}$ & $\begin{array}{l}226 \\
228\end{array}$ & $\begin{array}{l}199 \\
197\end{array}$ & $\begin{array}{l}262 \\
264\end{array}$ & $\begin{array}{l}267 \\
271\end{array}$ & $\begin{array}{l}63 \\
63\end{array}$ & $\begin{array}{l}267 \\
271\end{array}$ & 116 & $\begin{array}{l}222 \\
225\end{array}$ & 196 & 248 & 268 & 66 & $\begin{array}{l}16 \\
16\end{array}$ \\
\hline 38 & 279 & 120 & 236 & 197 & 272 & 279 & 63 & 280 & 116 & 231 & 195 & 255 & 280 & 66 & 19 \\
\hline $3 x$ & 200 & 120 & 218 & 195 & 234 & 220 & 63 & 264 & 117 & 220 & 192 & 236 & 248 & 66 & 16 \\
\hline
\end{tabular}

rms/WRI 92 
AFPENDIX B

Computer Code 


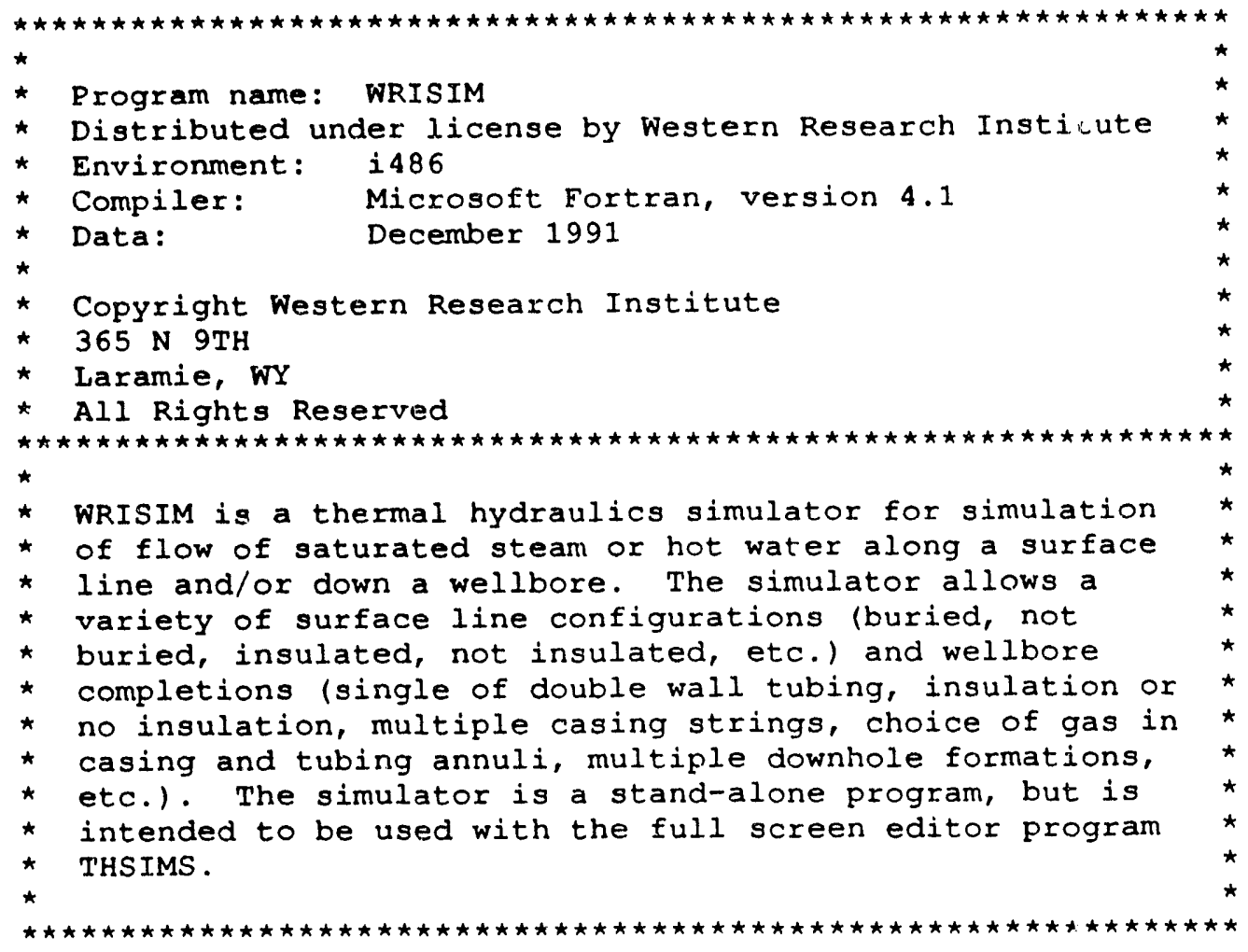

\section{\$STORAGE : 2}

$\star$

* Declaration of variables and common blocks and

* initialization of data.

REAL WS, D, A, D12, D1, A1, U2 (5000), KF (5000), ALPH (5000), UI1, UI2, T, RCI, CLEN, DEPTH, P, TV , X, E1, E2, PS, TIME, XF1, XF2, L1, AN1, AN2, RINS, DB, TM, WV, CGG, RW (5000), DO1, U1, K22, KCEM (5), D22, DEP, KS, K21, ALPHA (5),D11, DF (5), $\operatorname{CLC}(5), \operatorname{ID}(5), \mathrm{OD}(5), \mathrm{KC}(5), \mathrm{TF}(5), \operatorname{KHF}(5), \mathrm{K} 12, \mathrm{~K} 11, \mathrm{DW}(5)$, SINA2, U, M, CD21, DEL, DEZ, EINS, ECI, TCI, TINS, HIN, HRATE, SINA1, HL, DLO, DZO, H, DX, CDELTAP, RO1, RL1, RG1, LV1, HW1, ESL, D21B, D22B, K21B, ET1, ET2, KDTINS INTEGER J, L, C, XX, FIX1, ISI, N, M1, J1, JJJ,

C NCOUNT, I, NUM, K, NPC, NFAC, NPAG, NTWO, NHEAD, GINTUB, GINCAS

CHARACTER* 12 FII, FIO

CHARACTER $\star 15$ FLUID (2)

CHARACTER $\star 43$ TITLE

CHARACTER $\star 63$ TEXT (2)

CHARACTER $\star 31$ TEXT2 (2)

LOGICAL DT

COMMON /DTUB/ DT, D22A,D21B,D22B, K21B, ET1, ET2, KDTINS, GINTUB,

$\mathrm{C}$ GINCAS, UDT, PDT, PCAS

COMMON /COMM1/ U2, ALPH, RW, RINS, RCI, TIME, DEL, DEZ

COMMON /COMM2/ KF, TM, GG, EINS, ECI, ESL, TTINS

COMMON /COMM3/ TCI, TINS, TTB1, TTB2

COMMON /FREAD/ ALPHA, LC, ID, OD, KC, TF, KHF, DW, N, M1, U1,

$\mathrm{C}$ K22, KCEM, D22, DEPTH

COMMON /LREAD/ L, LEN, WV, D11, D12, E1, ISL, K11, K12, T, DB, $\mathrm{C}$ $\mathrm{KS}, \mathrm{J} 1, \mathrm{X}, \mathrm{P}, \mathrm{TV}, \mathrm{M}, \mathrm{D} 21, \mathrm{E} 2, \mathrm{~K} 21, \mathrm{AN} 2, \mathrm{AN} 1$

COMMON /SATS/ DELTAP,DX, RO1, RL1, RG1, LV1, HW1

COMMON /MISC/ FII, FIO,TITLE, NPCSL, NPCWB

DATA FLUID/'SATURATED STEAM', 'HOT WATER'/ 


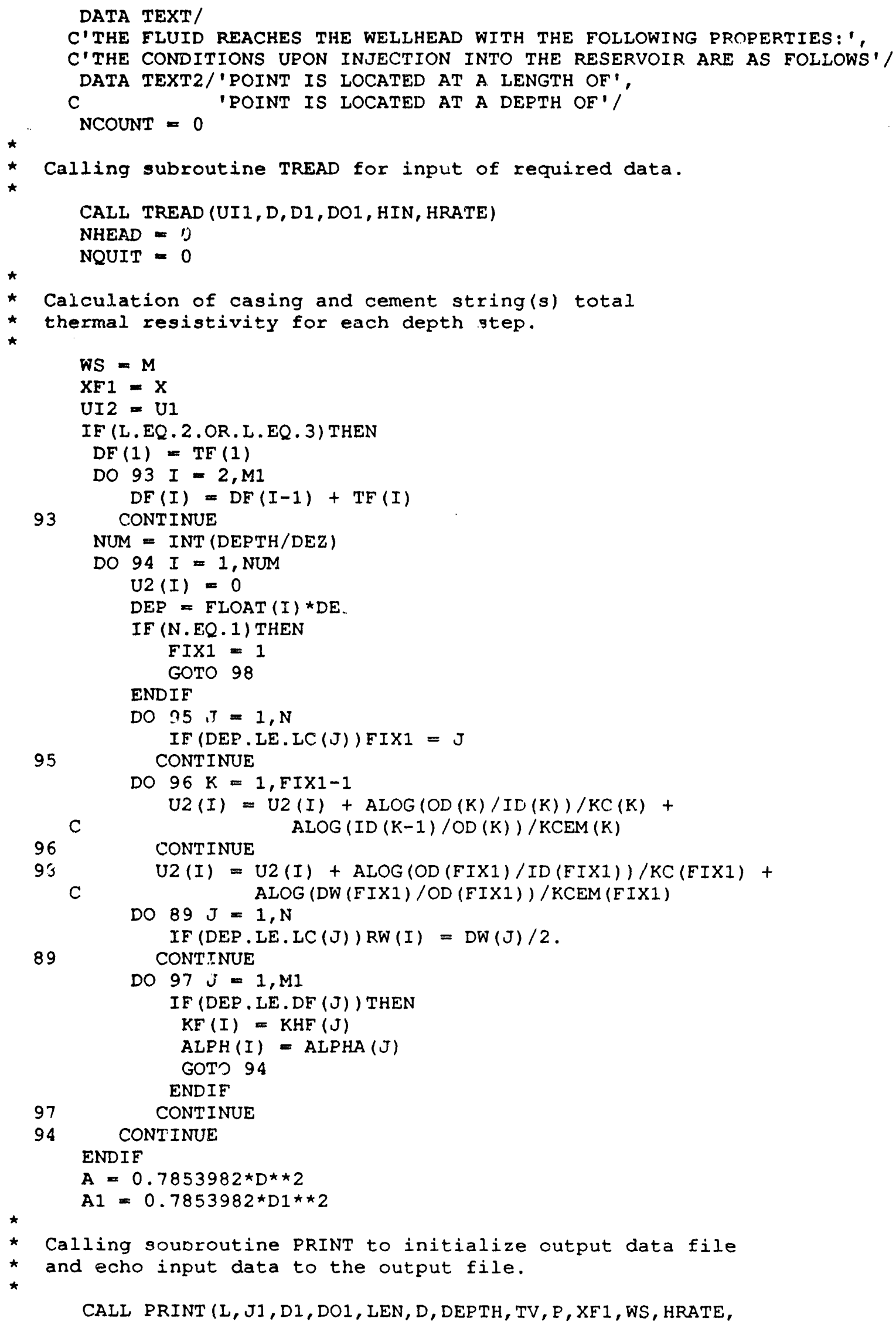

CALI PRINT (L, J1, D1, DO1, LEN, D, DEPTH, TV, P, XF1, WS, HRATE, 


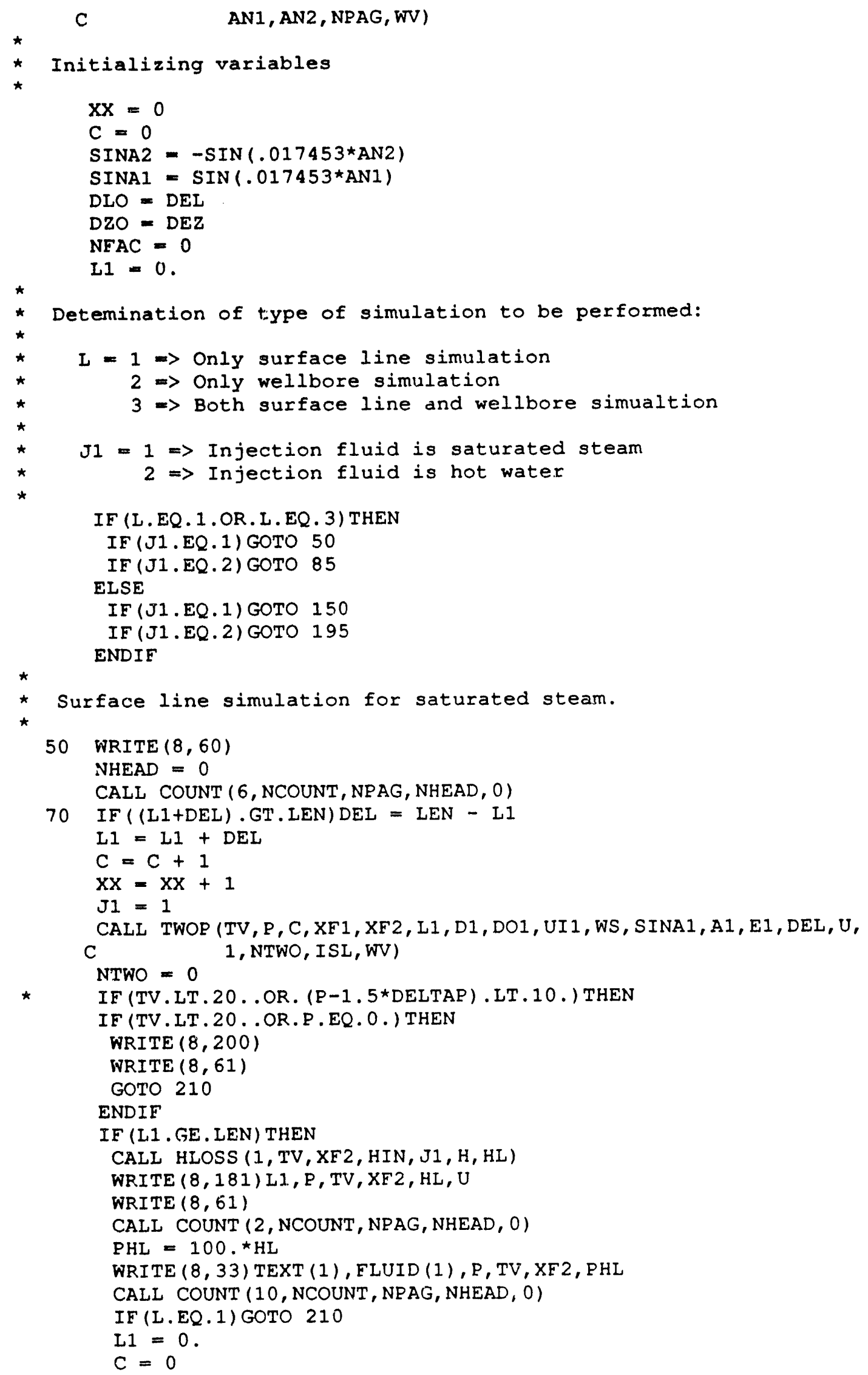




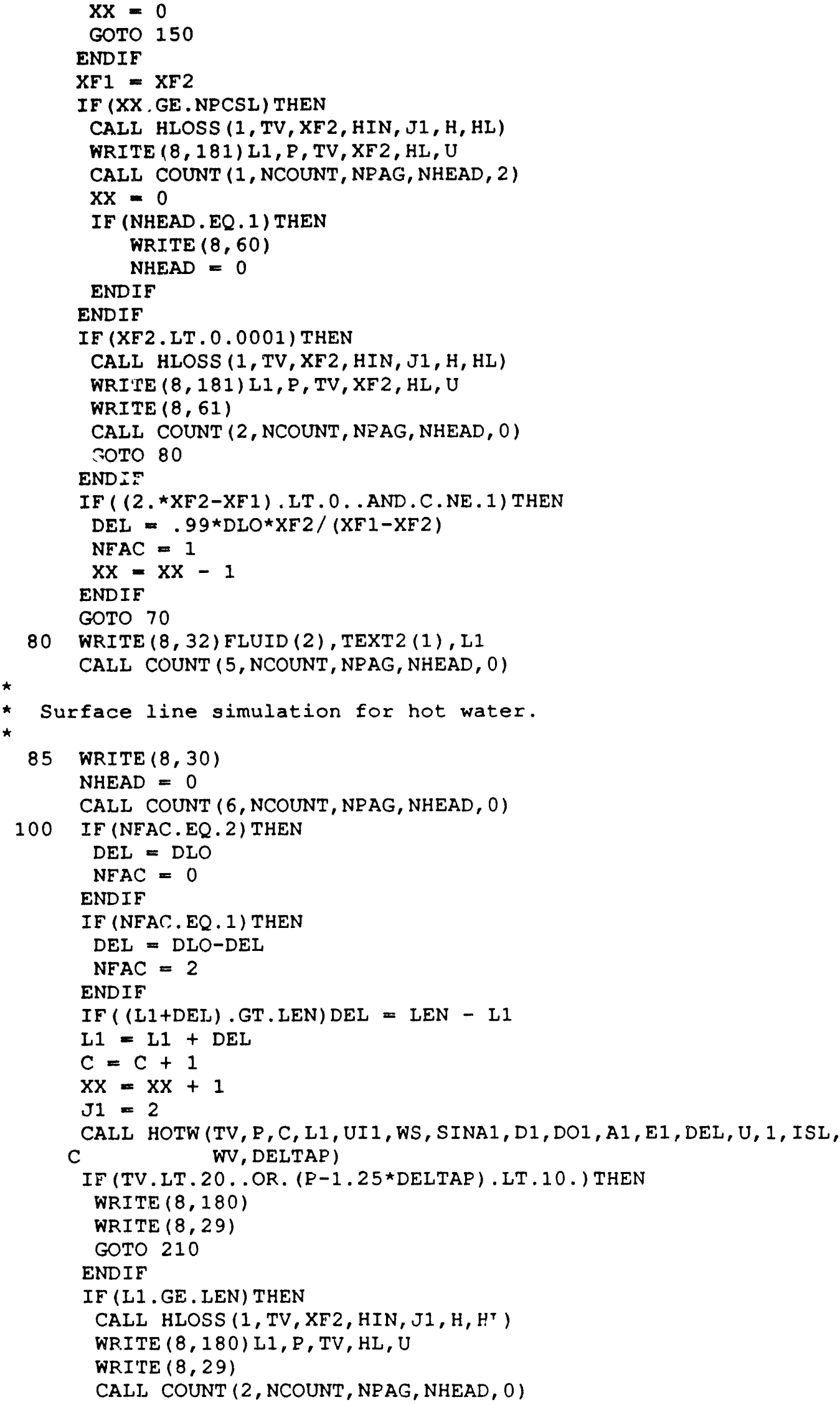




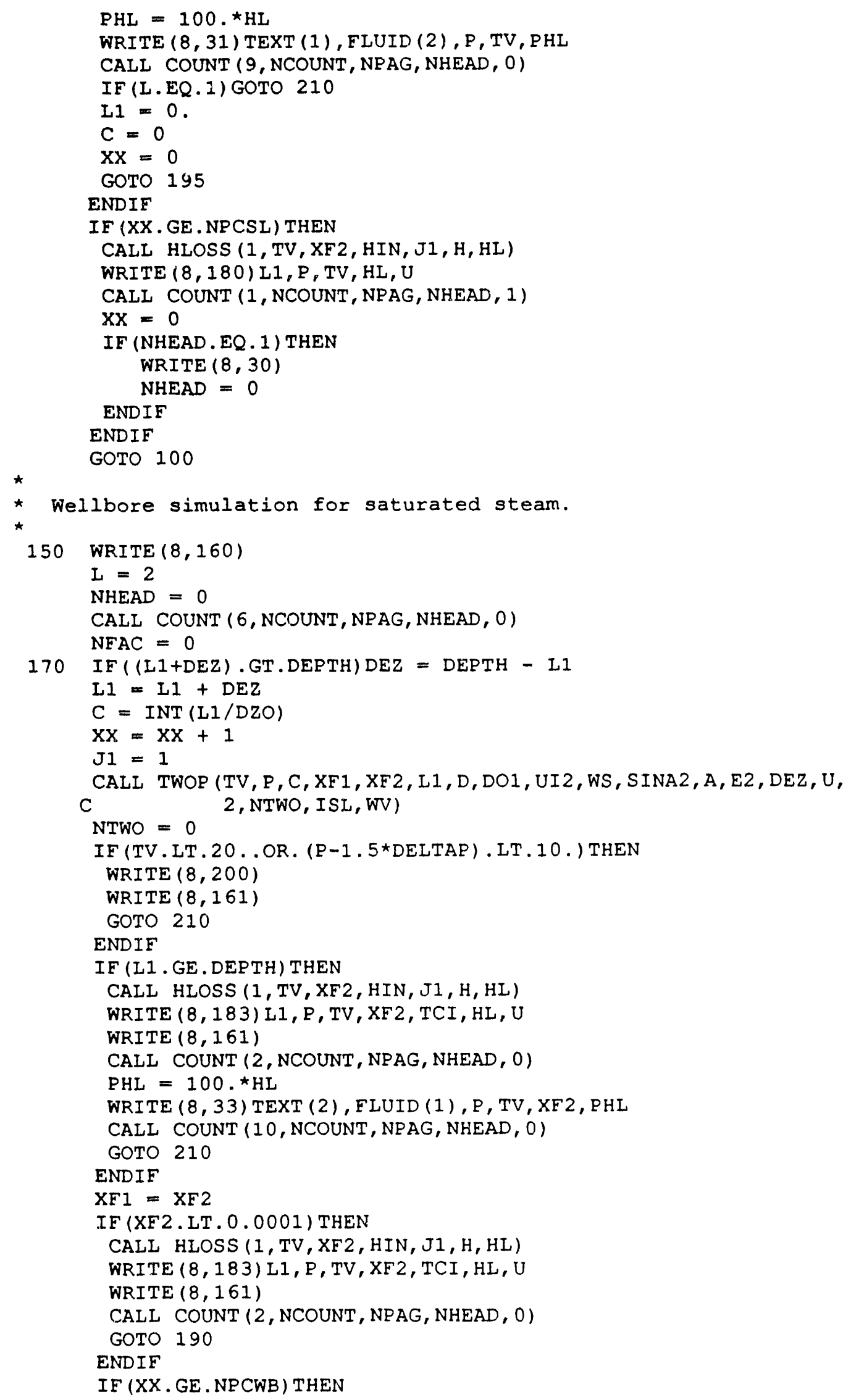




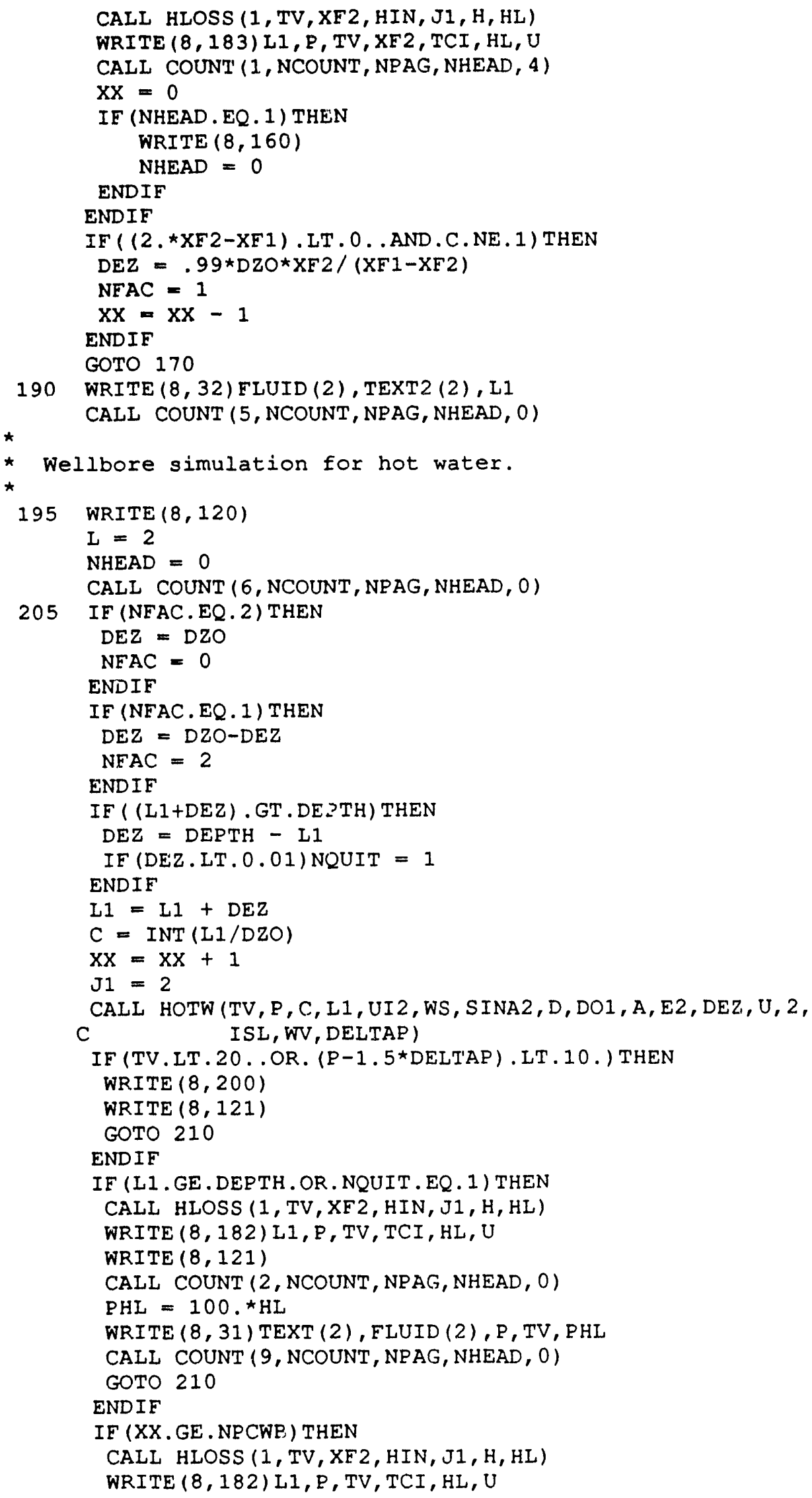




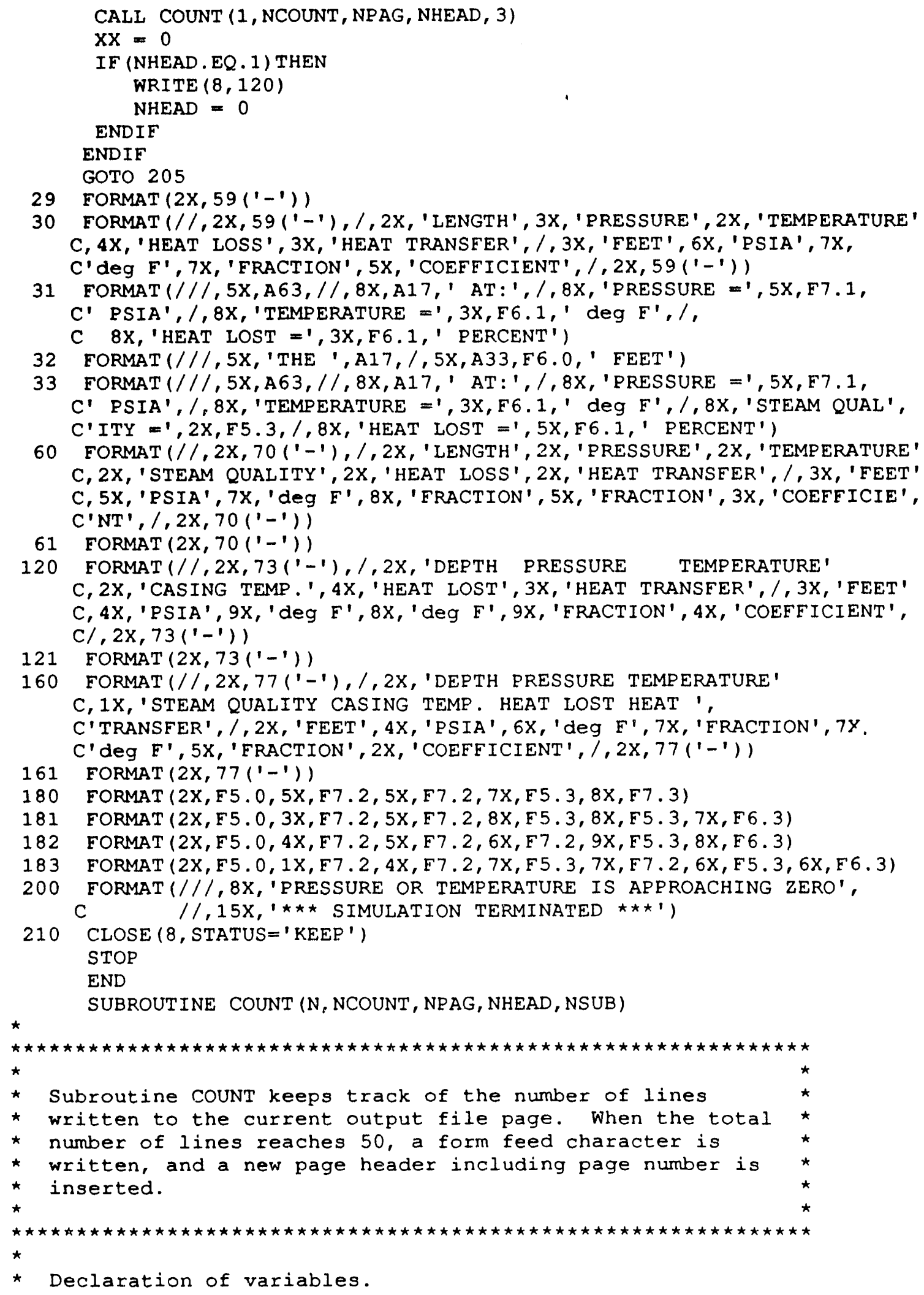

INTEGER N, NCOUNT, NPAG, IYR, IMON, IDAY, IHR, IMIN, ISEC, I100TH, NHEAD, NS CHARACTER $\star 3$ FF

$F F=\operatorname{CHAR}(12)$ 


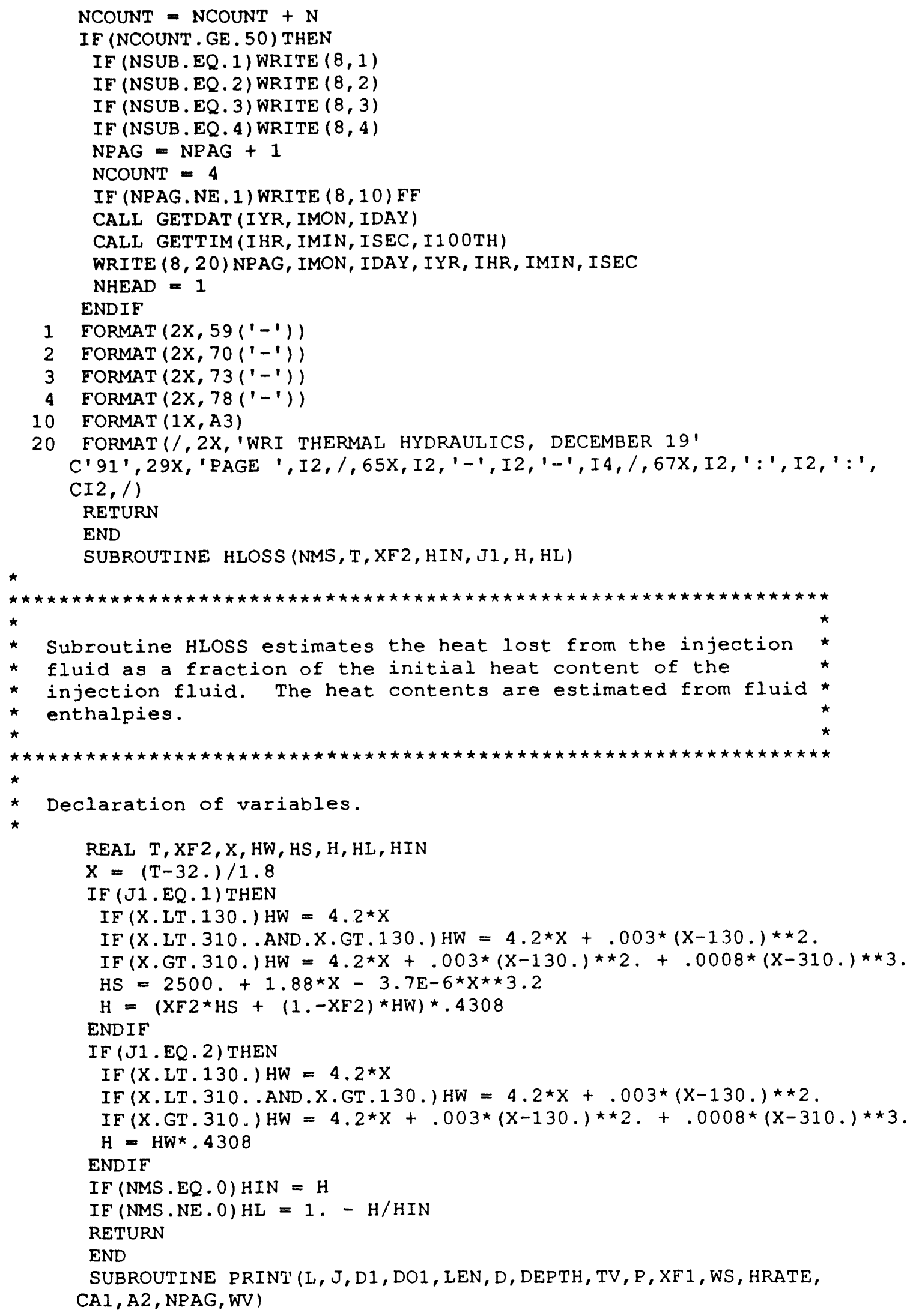




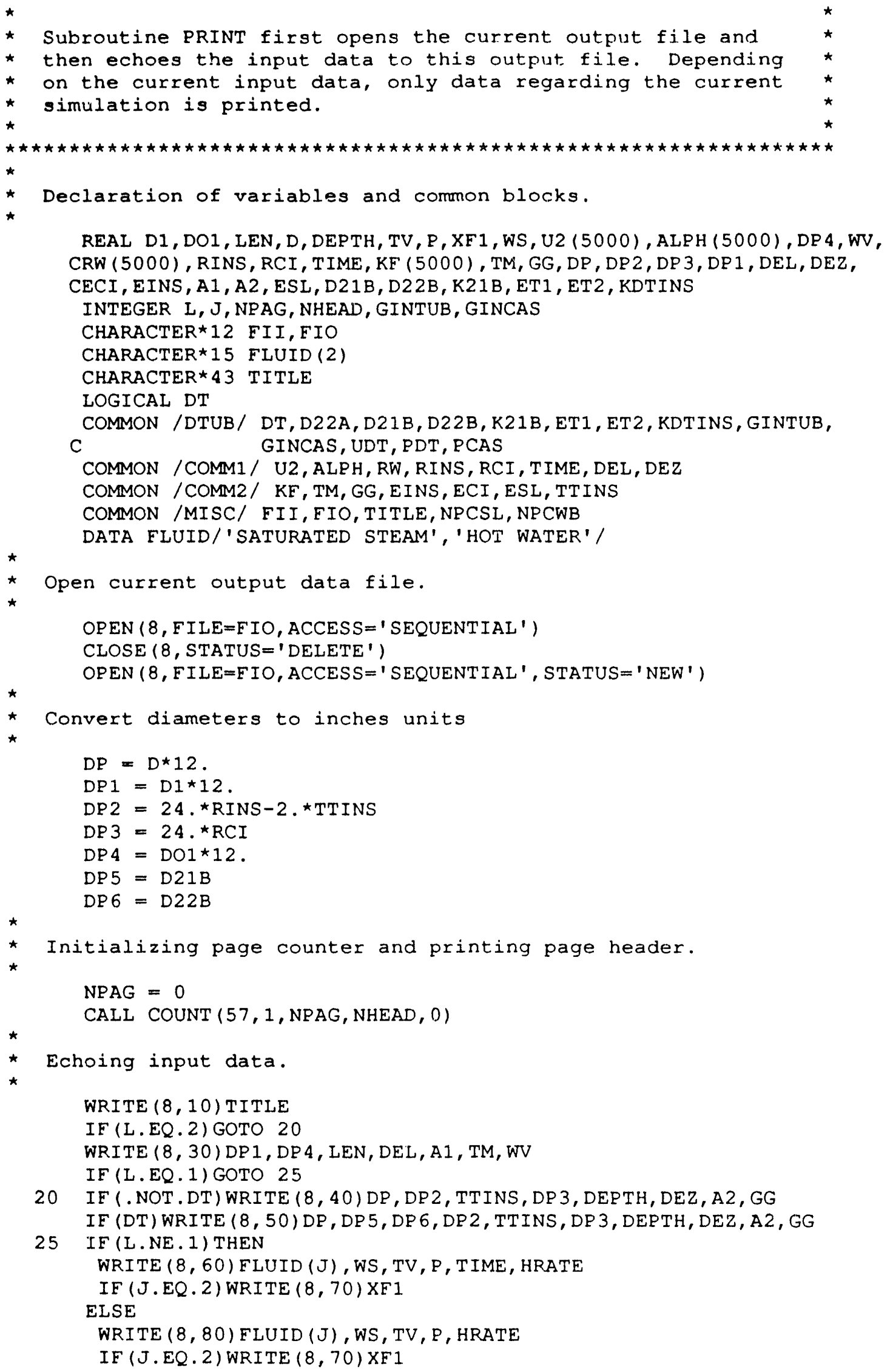


ENDIF

WRITE $(8,85)$

CALL COUNT $(57,1$, NPAG, NHEAD, 0$)$

10 FORMAT $(/ /, 5 X$, 'TITLE:, A $43, / /$,

C $5 X$, 'INPUT VARIABLES', $/, 5 X, 15('=1), / / 1$

30 FORMAT ( $5 x$, 'SURFACE IINE' $, 1,5 \mathrm{X}, 12\left(^{\prime}=1\right), / /, 5 \mathrm{X}$, 'INNER DIAMETER ', C27 ('.' '), 3X, F5 .2, 2X, 'INCHES', /,5X, 'OUTER DIAMETER ', $27(', 1), 3 \mathrm{X}$, CF5. 2, 2X, 'INCHES', /, 5X, 'LENGTH ', 35 (' ' '), 1X, F7.1, 2X, 'FEET' , /, 5X, C'STEP SIZE FOR SURFACE LINE ', 15('.' '), 2X, F6.1,2X, 'FEET', /, 5X, C'ANGLE OF INCLINATION (FROM HORIZONTAL) ', 3('.' '), $2 \mathrm{X}, \mathrm{F} 6.1,2 \mathrm{X}$, 'DEGR' C, 'EES', /, 5X, 'SURFACE TEMPERATURE ', $22(' .1), 3 \mathrm{X}, \mathrm{F} 5.1,2 \mathrm{X}$, 'DEGREES F', $\mathrm{C} /, 5 \mathrm{X}$, 'AVERAGE SURFACE WIND VELOCITY ', $\left.12 !^{\prime} \cdot{ }^{\prime} '\right), 3 \mathrm{X}, \mathrm{F} 5.1,2 \mathrm{X}, \mathrm{MPH}^{\prime}, /$ )

40 FORMAT (5X, 'WELLBORE (SINGLE WALL TUBING) $1,1,5 \mathrm{X}, 29(1=1), 1 /$, C $5 \mathrm{X}$, 'TUBING INNER DIAMETER ', 20 (' ' '), 3X, F5.2, $2 \mathrm{X}$, ' INCHES', 1 , C $5 X$, 'TUBING OUTER DIAMETER ', 20 (' ' '), 3X, F5.2, $2 \mathrm{X}$, 'INCHES', /,

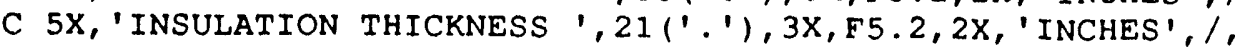
C $5 \mathrm{X}$, 'CASING INNER DIAMETER ', $20\left(^{\prime}, '\right), 3 \mathrm{X}, \mathrm{F} 5.2$, C2X, 'INCHES', /, 5X, 'DEPTH ', 36('.' ', 1X, F7.1,2X,' FEET', /, 5X, 'STEP S', C'IZE FOR WELLBORE ', 19 ('.' '), 2X, F6.1,2X, 'FEET', /, 5X, 'ANGLE OF INC',

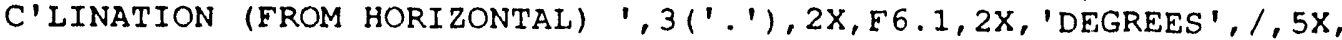
C'GEOTHERMAL GRADIENT ', $22(', '), 1 X, F 7.5,2 X, '$ DEGREES F/FEET', $/$ )

50 FORMAT (5X, 'WELLBORE (DOUBLE WALL TUBING) ', /,5X, 29('=1), /1,

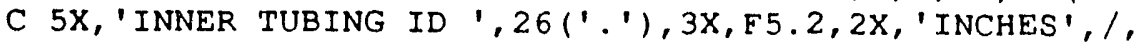
C $5 X$, 'INNER TUBING OD ', $26(', '), 3 X, F 5.2,2 X$, ' INCHES', $/$, C 5X, 'OUTER TUBING ID ', $26(', '), 3 \mathrm{X}, \mathrm{F} 5.2,2 \mathrm{X}$, ' INCHES', $/$, C $5 x$, 'OUTER TUBING OD ', $26(', '), 3 \mathrm{X}, \mathrm{F} 5.2,2 \mathrm{X}$, ' INCHES', $/$, C 5X,' INSULATION THICKNESS ', 21 ('.' '), 3X, F5.2, 2X, 'INCHES', /, C $5 \mathrm{X}$, 'CASING INNER DIAMETER ', $20(', '), 3 \mathrm{X}, \mathrm{F} 5.2$, C2X, 'INCHES', /, 5X, 'DEPTH ',36('.' '), 1X, F7.1,2X, 'FEET',/,5X, 'STEP S', C'IZE FOR WELLBORE ', 19('.' ', 2X,F6.1,2X, 'FEET', /,5X, 'ANGLE OF INC', C'LINATION (EROM HORIZONTAL) ', 3(' .' '), 2X, F6.1, 2X, 'DEGREES' , /, 5X, C'GEOTHERMAL GRADIENT ',22('.' '), 1X,F7.5, 2X, 'DEGREES F/FEET', /)

60 FORMAT (5X, 'OTHER INPUT VARIABLES', $/, 5 \mathrm{X}, 21\left(^{\prime}=1\right), / 1,5 \mathrm{X}$, ' THE', C' INJECTION FLUID IS ', A17, /,5X, 'MASS FLOWRATE', C1X, 28 (' . '), 3X, F5 . 2, 2X, 'LBM/SEC', /, 5X, 'TEMPERATURE' , 1X, 30 (' .'),

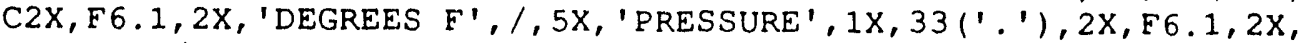
C'PSIA', /, 5X, 'INJECTION TIME', 1X, $27(', '), 1 X, E 7.1,2 X$, 'DAYS', /, C5X, 'HEAT INJECTION RATE', $1 X, 22(' . '), 1 X, F 7.1,2 \mathrm{X}$, 'BTU/SEC')

70 FORMAT (5X, 'STEAM QUALITY', $1 X, 28(', '), 3 X, F 5.3)$

80 FORMAT (5X, 'OTHER INPUT VARIABLES', $/, 5 \mathrm{X}, 21('=1), 1 /, 5 \mathrm{X}$, 'THE', C' INJECTION FLUID IS ', A17,/,5X, 'MASS FLOWRATE',1X, 28('.'),' C $3 \mathrm{X}, \mathrm{F} 5.2,2 \mathrm{X}$, 'LBM/SEC' , /,5X, 'TEMPERATURE' , 1X, 30 ('.' '), 2X, F6.1,

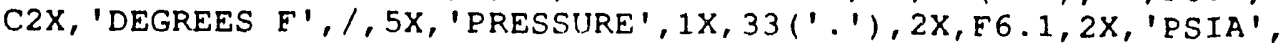
$\mathrm{C} /, 5 \mathrm{X}$, 'HEAT INJECTION RATE', $1 \mathrm{X}, 22(' .1), 1 \mathrm{X}, \mathrm{F} 7.1,2 \mathrm{X}$, 'BTU/SEC')

85 FORMAT $(/ /, 5 X$, 'NOTE: HEAT TRANSFER COEFFICIENTS ARE EXPRESSED IN', C1IX, 'Btu/hr-ft-degF'')

100 FORMAT (A1)

WRITE $(8,110)$

110 FORMAT $(/ /, 5 X, '$ SIMULATION RESULTS FOR INJECTION: ', /,5X, 33('z')) RETURN

END

$\star$ SUBROUTINE TREAD (UI1, D, D1, D99, HIN, HRATE)

$\star \star \star \star \star \star \star \star \star \star \star \star \star \star \star \star \star \star \star \star \star \star \star \star \star \star \star ~$
$\star$
$\star$ Subroutine TREAD reads input data from the current input file
$\star$ which is specified on the command line. Some data processing $\star$
$\star \quad$ is performed (e.g. estimation of surface line and tubing
$\star \quad$ thermal resistances).
$\star \quad$ 


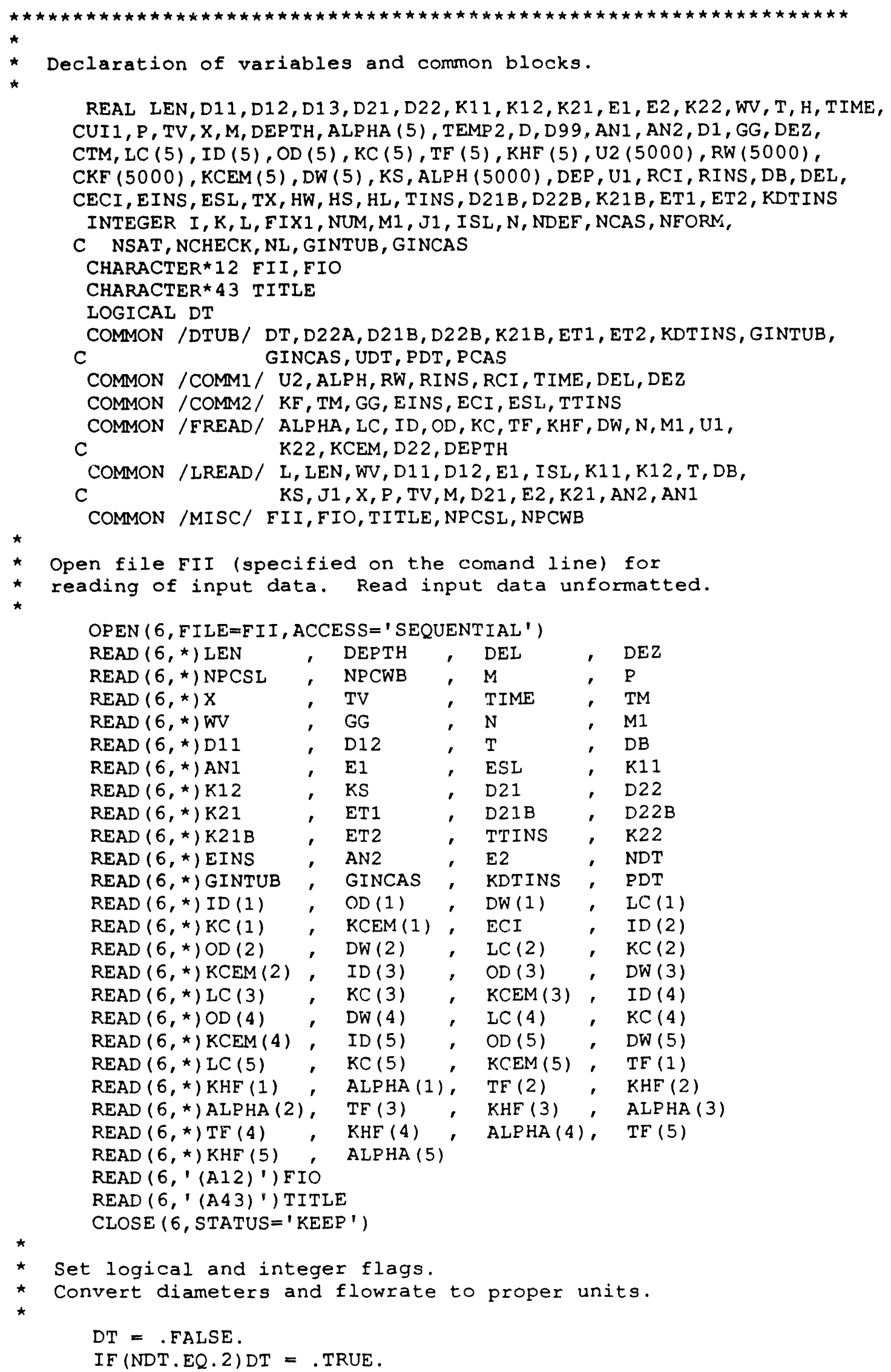




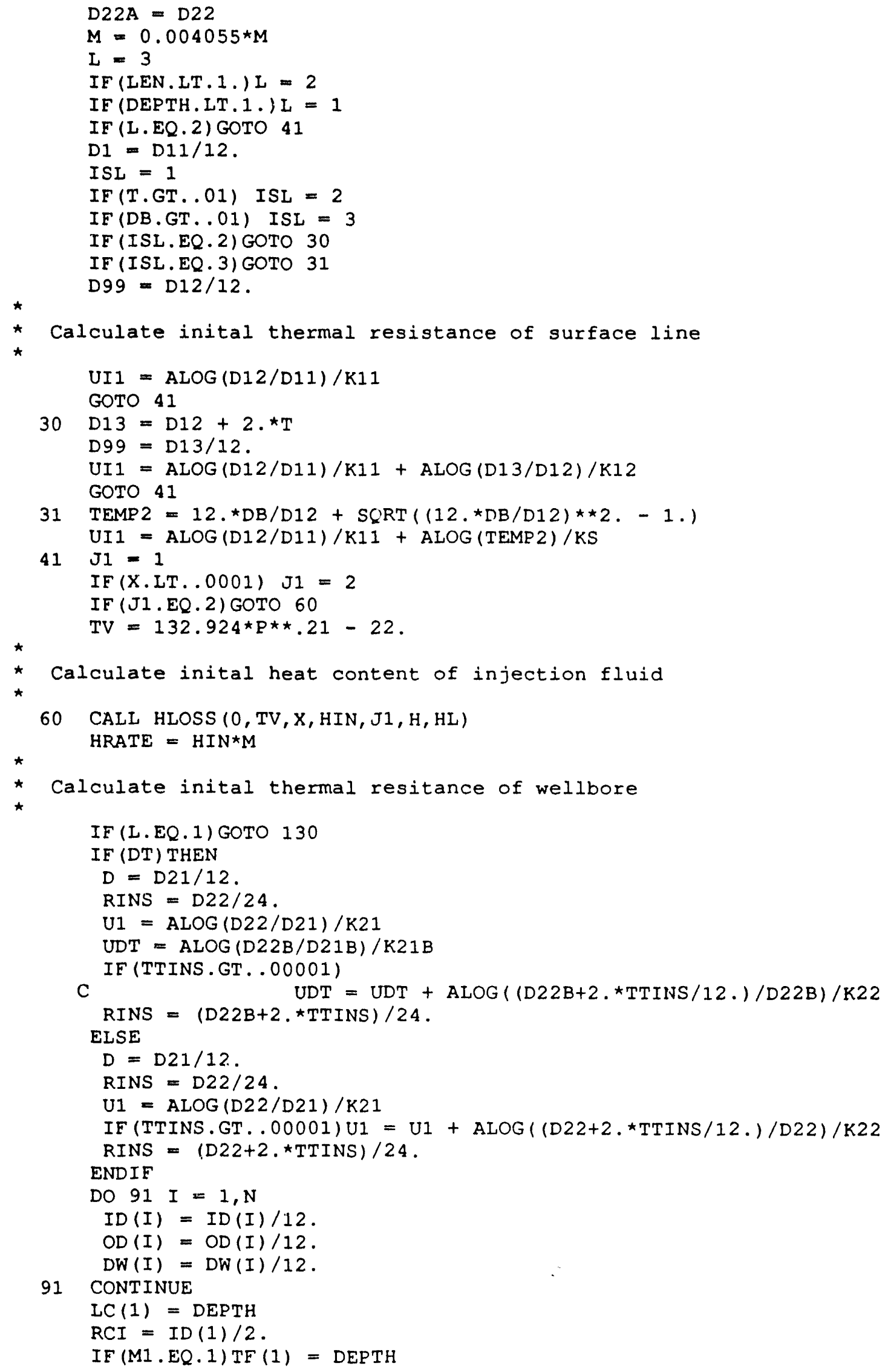




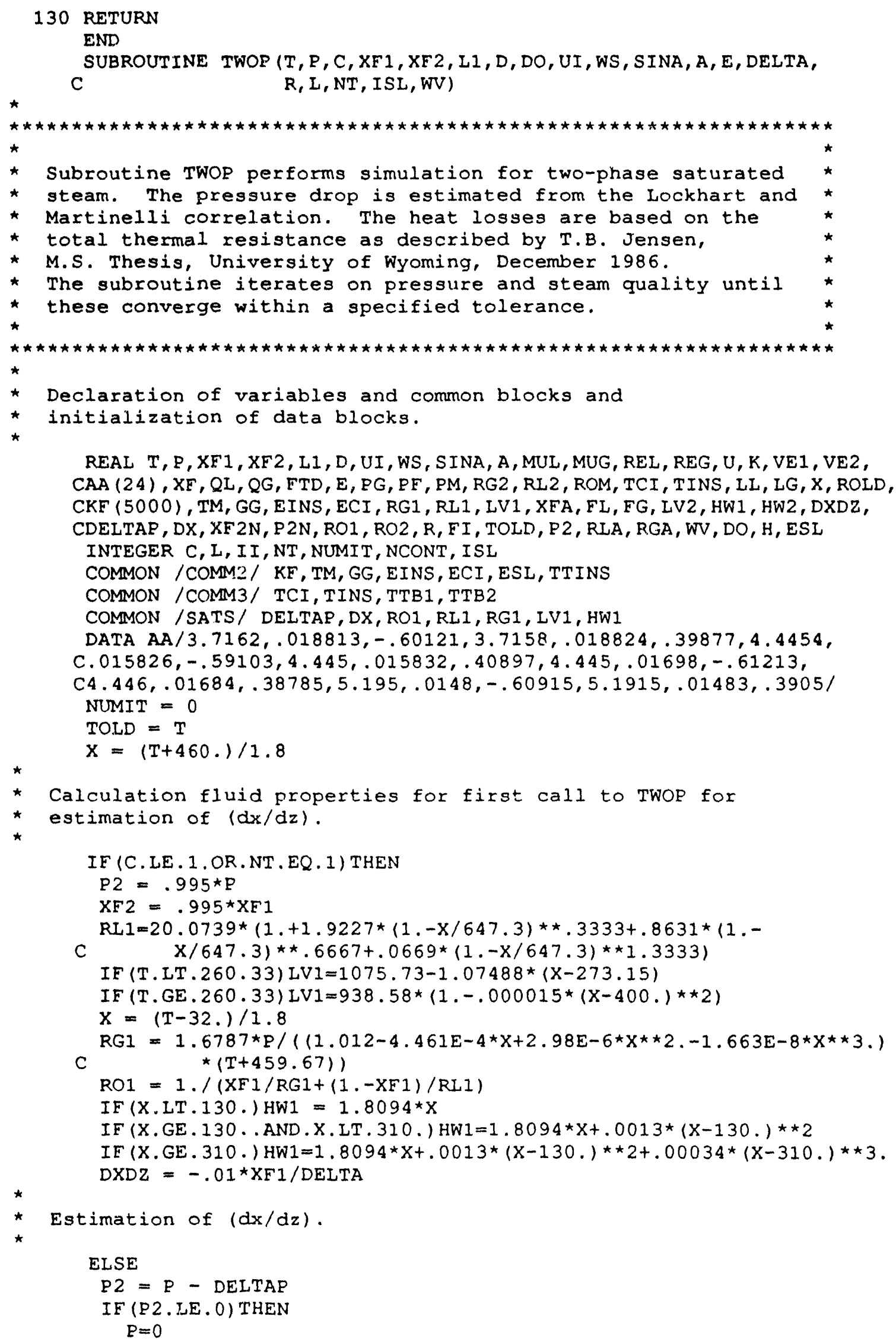

REAL T, P, XF1, XF2, LI, D, UI, WS, SINA, A, MUL, MUG, REL, REG, U, K, VE1, VE2, CAA (24) , XF, QL, QG, FTD, E, PG, PF, PM, RG2, RI2, ROM, TCI, TINS, LL, LG, X, ROLD, CKF (5000), TM, GG, EINS, ECI, RG1, RL1, LV1, XFA, FL, FG, LV2, HW1, HW2, DXDZ , CDELTAP, DX, XF2N, P2N, RO1, RO2, R, FI, TOLD, P2, RLA, RGA, WV, DO, H, ESI

INTEGER C, L, II, NT, NUMIT, NCONT, ISL

COMMON /COMM2/ KF, TM, GG, EINS, ECI, ESL, TTINS

COMMON /COMM3/ TCI, TINS, TTB1, TTB2

COMMON /SATS/ DELTAP, DX, RO1, RL1, RG1, LV1, HW1

DATA AA/3.7162,.018813,-.60121, 3.7158,.018824,.39877,4.4454,

C. $015826,-.59103,4.445, .015832, .40897,4.445, .01698,-.61213$,

C4.446,.01684,.38785,5.195,.0148,-.60915,5.1915,.01483,.3905/

NUMIT $=0$

TOLD $=T$

$X=(T+460) /$.

* Calculation fluid properties for first call to TWOP for

* estimation of $(\mathrm{dx} / \mathrm{dz})$.

IF (C.LE.1.OR.NT.EQ.1) THEN

$\mathrm{P} 2=.995 * \mathrm{P}$

$\mathrm{XF} 2=.995 * \mathrm{XF} 1$

$R L 1=20.0739 \star(1 .+1.9227 \star(1 .-x / 647.3) \star \star .3333+.8631 *(1 .-$

C

$x / 647.3) \star \star .6667+.0669 \star(1 .-x / 647.3) \star \star 1.3333)$

IF (T.IT. 260.33) LV $1=1075.73-1.07488 *(X-273.15)$

IF (T.GE.260.33) LV1 $=938.58 *(1 .-.000015 *(X-400.) \star \star 2)$

$X=(T-32) /$.

$R G 1=1.6787 \star P /((1.012-4.461 E-4 \star X+2.98 E-6 \star X \star \star 2 .-1.663 E-8 \star X \star \star 3)$.

C $\star(T+459.67))$

$\mathrm{RO} 1=1 . /(\mathrm{XF} 1 / \mathrm{RG} 1+(1 .-\mathrm{XF} 1) / \mathrm{RI} 1)$

IF (X.LT.130.) HW1 $=1.8094 \star X$

IF (X.GE.130 . AND.X.LT. 310.) HW $1=1.8094 \star X+.0013 \star(X-130.) \star \star 2$

IF (X.GE. 310.) HW $1=1.8094 * X+.0013 *(X-130.) \star \star 2+.00034 *(X-310.) \star \star 3$. $\mathrm{DXDZ}=-.01 \star \mathrm{XF} 1 / \mathrm{DELTA}$

$\star$

Estimation of $(d x / d z)$. 


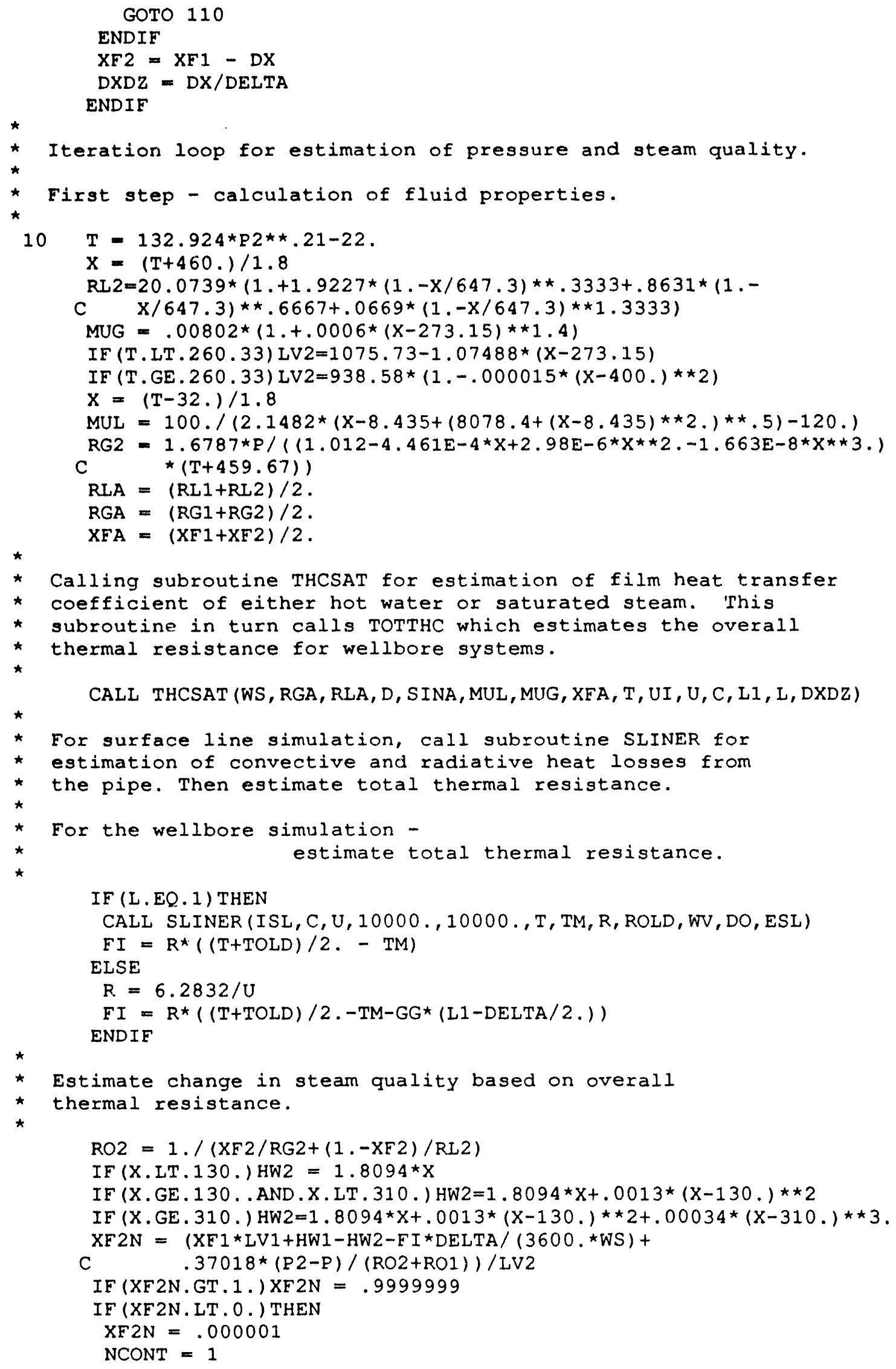




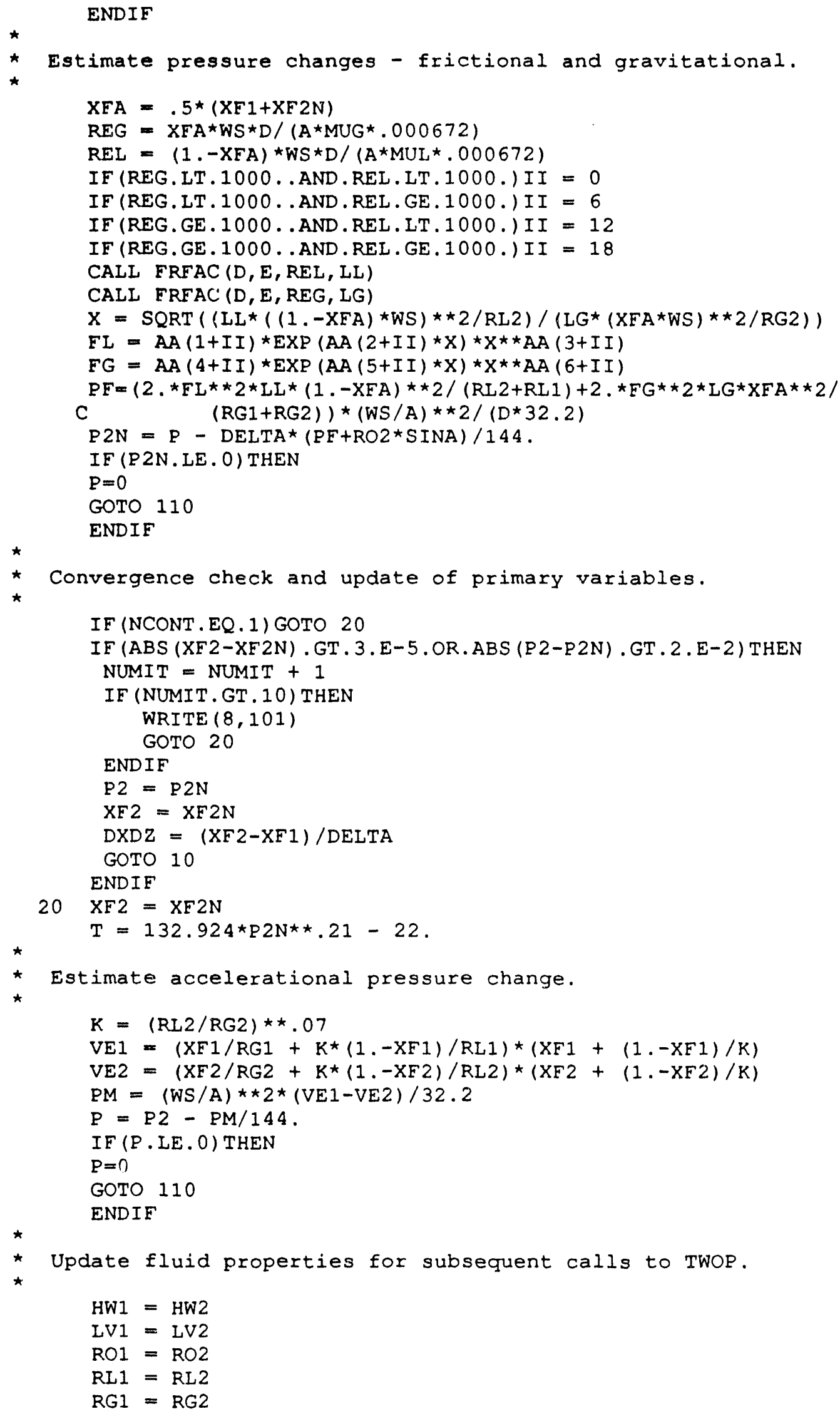




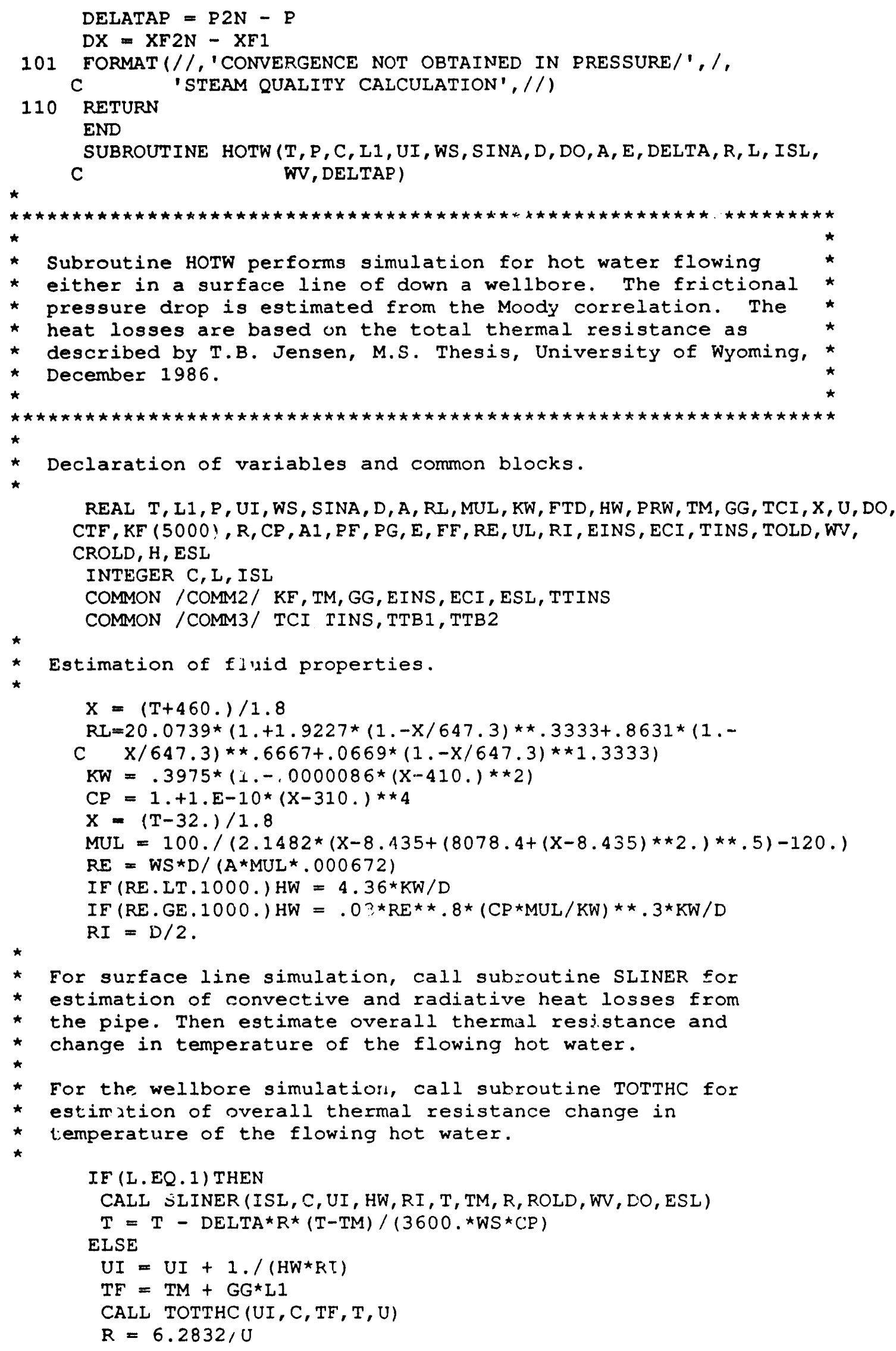

REAL T, L1, P, UI, WS, SINA, D, A, RI, MUL, KW, FTD, HW, PRW, TM, GG, TCI, X, U, DO, $C T F, K F(5000), R, C P, A I, P E, P G, E, F F, R E, U L, R I, E I N S, E C I, T I N S, T O L D, W J$, CROLD, H, ESL

INTEGER C, L, ISL

COMMON /COMM2/ KF, TM, GG, EINS, ECI, ESL, TTINS

COMMON /COMM3/ TCI TINS, TTB1, TTB2

Estimation of flidid properties. 


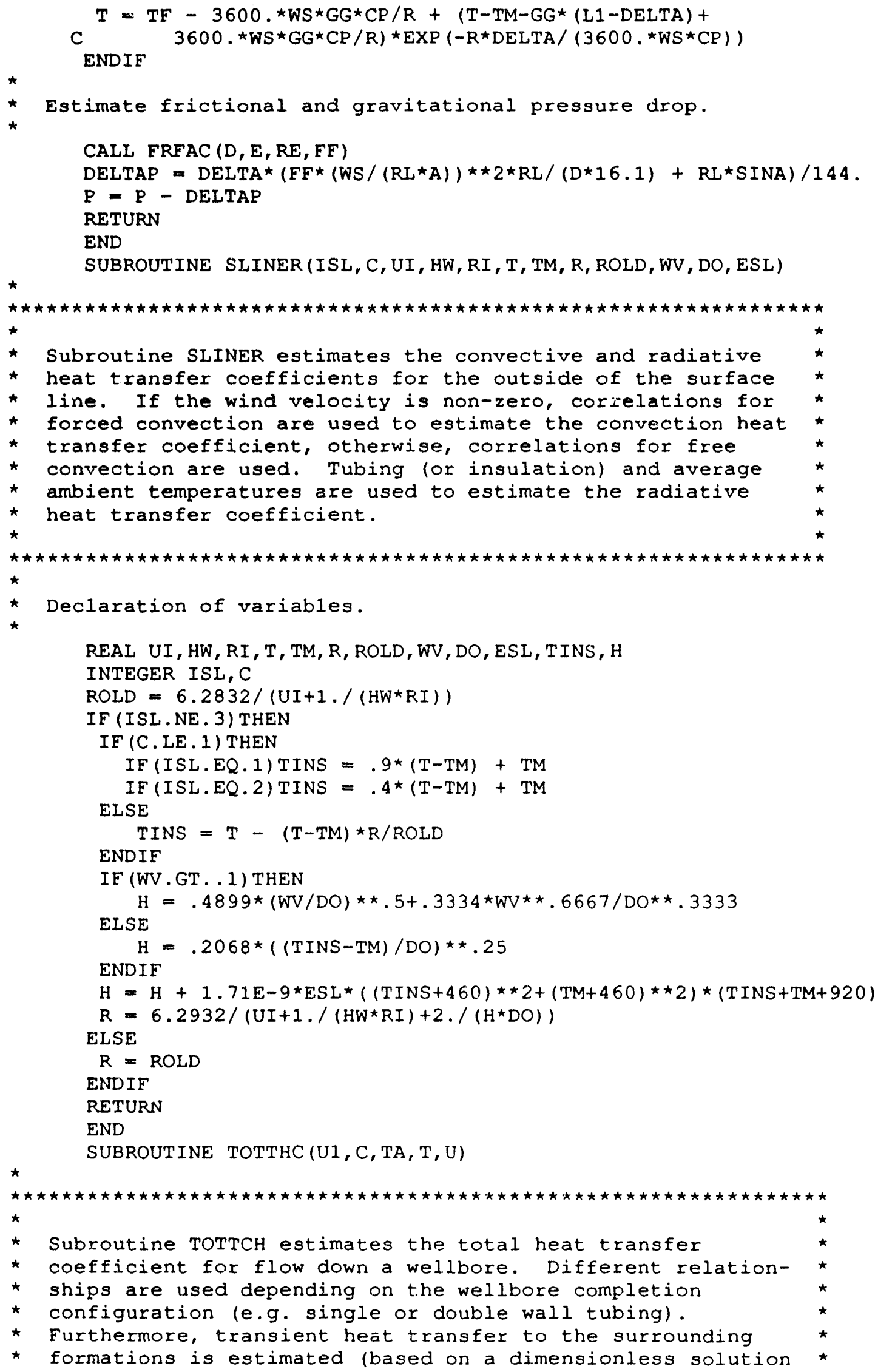




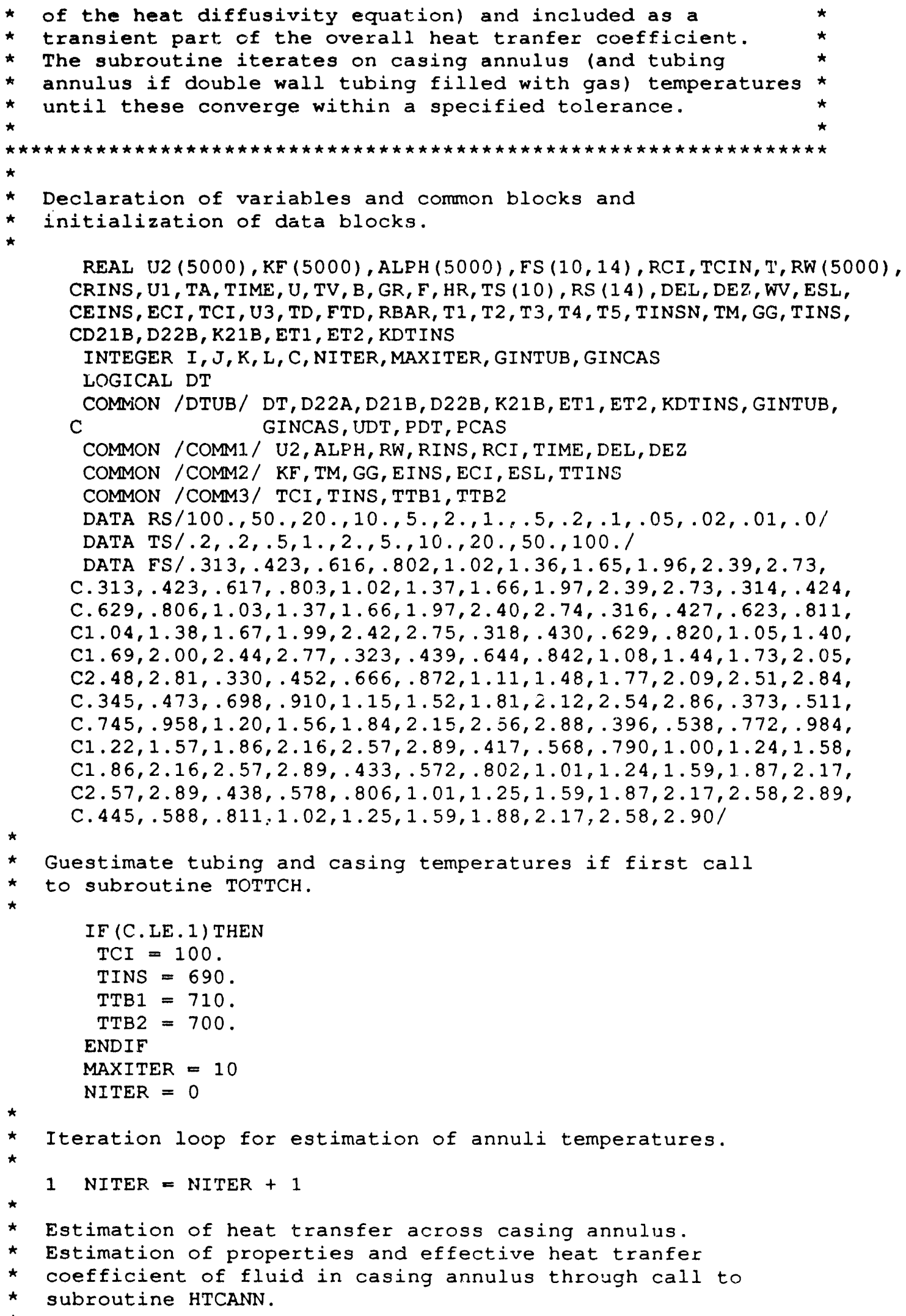

CALL HTCANN (GINCAS, RINS, RCI, TINS, TCI, EINS, ECI, PCAS, HR2) $\mathrm{U} 3=\mathrm{U} 1+1 . /(\mathrm{HR} 2 \star$ RINS $)+\mathrm{U} 2(\mathrm{C})$ 


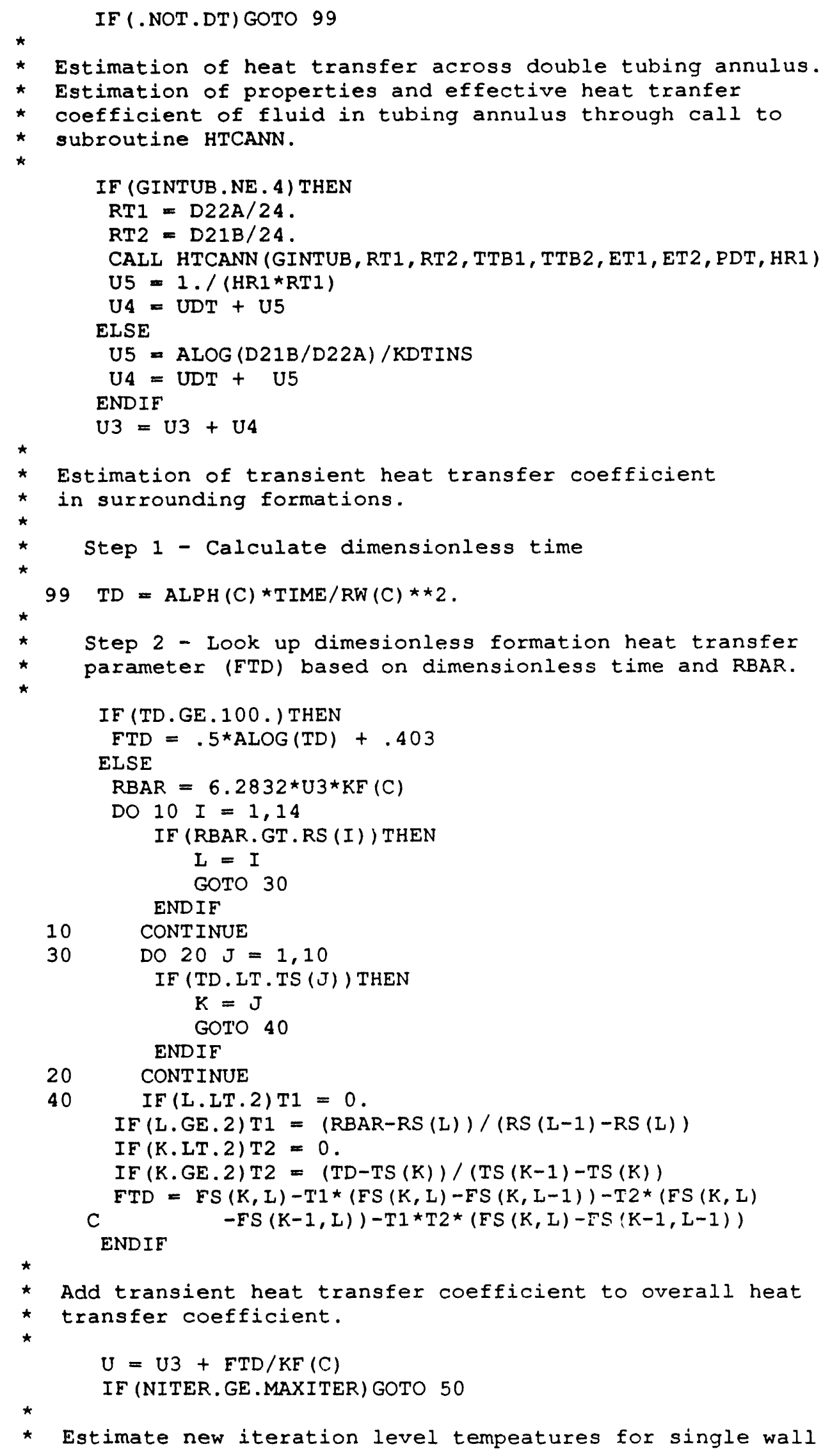


* tubing based on fractional heat transfer resistances.

IF (. NOT.DT) THEN

$\mathrm{TCIN}=\mathrm{TA}+(\mathrm{T}-\mathrm{TA}) *(\mathrm{U} 2(\mathrm{C})+\mathrm{FTD} / \mathrm{KF}(\mathrm{C})) / \mathrm{U}$

$T I N S N=T-(T-T A) \star U 1 / U$

DTMAX = AMAXI (ABS (TCIN-TCI), ABS (TINSN-TINS))

TTB1N $=$ TTB1

$T T B 2 N=T T B 2$

* Estimate new iteration level tempeatures for double wall

* tubing based on fractional heat transfer resistances.

ELSE

$\mathrm{TCIN}=\mathrm{TA}+(\mathrm{T}-\mathrm{TA}) *(\mathrm{U} 2(\mathrm{C})+\mathrm{FTD} / \mathrm{KF}(\mathrm{C})) / \mathrm{U}$

TINSN $=\mathrm{TA}+(\mathrm{T}-\mathrm{TA}) *(1 . /(\mathrm{HR} 2 \star \mathrm{RINS})+\mathrm{U} 2(\mathrm{C})+\mathrm{FTD} / \mathrm{KF}(\mathrm{C})) / \mathrm{U}$

$T T B 1 N=T-(T-T A) \star U 1 / U$

$T T B 2 N=T-(T-T A) *(U 1+U 5) / U$

DTMAX1 $=$ AMAX1 (ABS (TCIN-TCI), ABS (TINSN-TINS))

DTMAX2 $=$ AMAX1 (ABS (TTB1N-TTB1), ABS (TTB2N-TTB2))

DTMAX = AMAX1 (DTMAX1, DTMAX2)

ENDIF

$\star$

* Update casing and tubing temperatures.

IF (DTMAX, GT . . 002) THEN

$T C I=T C I N$

TINS $=$ TINSN

TTB1 $=$ TTB1N

$T T B 2=T T B 2 N$

GOTO 1

ENDIF

* End of iteration loop - update casing and tubing temperatures.

50 TCI $=$ TCIN

TINS $=$ TINSN

$T T B 1=T T B 1 N$

$T T B 2=T T B 2 N$

RETURN

END

SUBROUTINE FRFAC (D, E, RE, F)

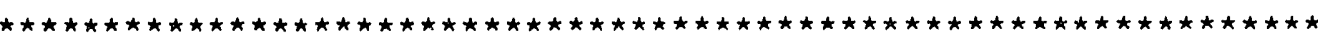

$\star$

* Subroutine FRFAC estimates friction factors

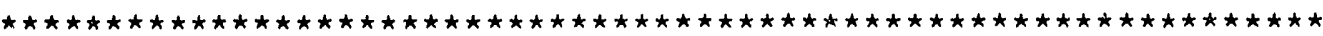

$\star$

REAL $D, E, R E, F, A, B, C$

IF (RE.LT.1000.) THEN

$F=16 . / R E$

ELSE

$A=-2 . \star A L O G 10(E /(3.7 \star D)+12 . / R E)$

$B=-2 .{ }^{\star} A L O G 10(E /(3.7 \star D)+2.51 \star A / R E)$

$C=-2 . \star A L O G 10(E /(3.7 \star D)+2.51 \star B / R E)$

$F=((A-(B-A) \star \star 2 /(C-2 . \star B+A)) \star \star(-2)) / 4$.

ENDIF

RETURN

END

SUBROUTINE HTCANN (GAS, RI, RO, TI, TO, EI, EO, P, HANN) 


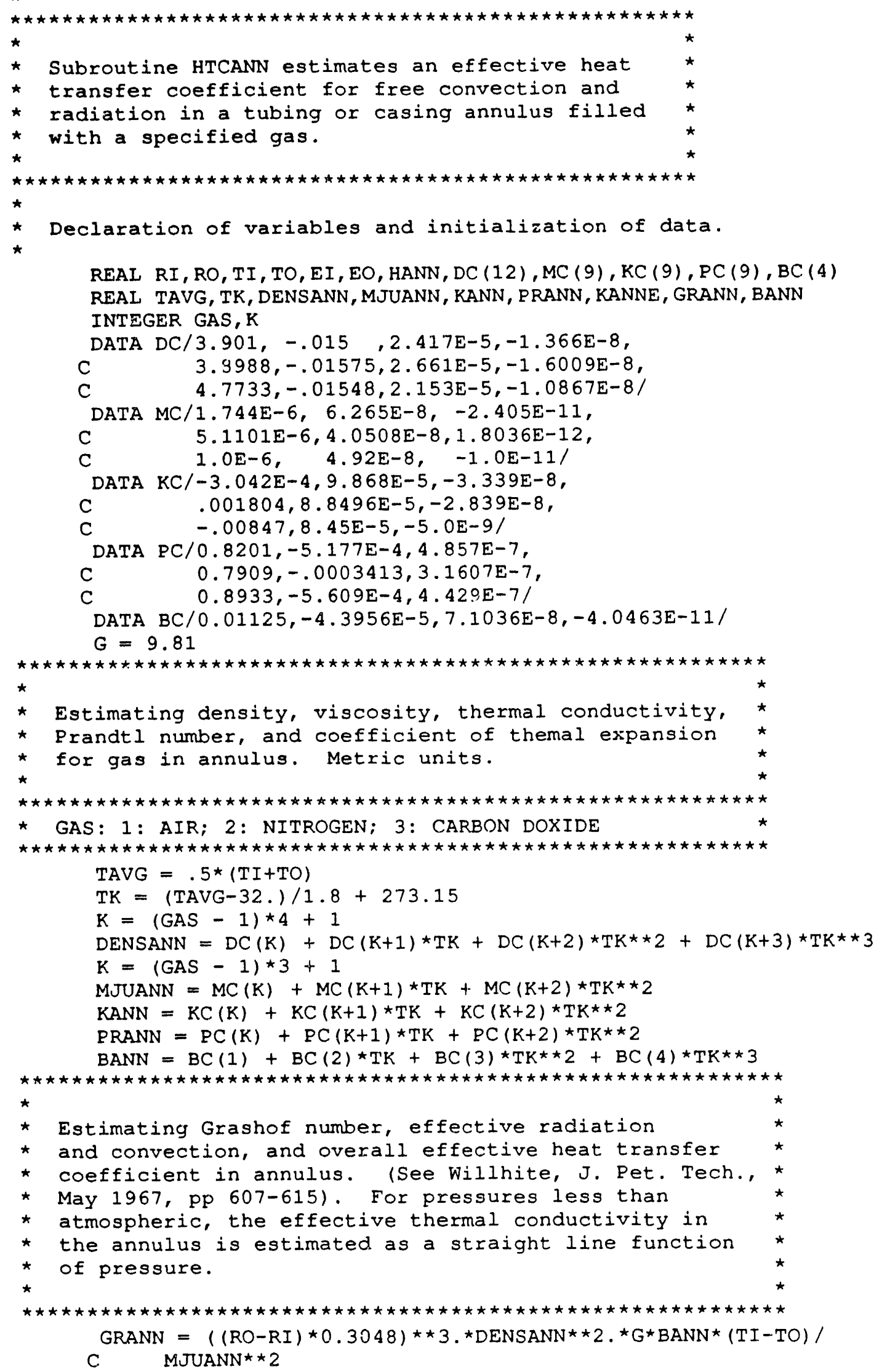




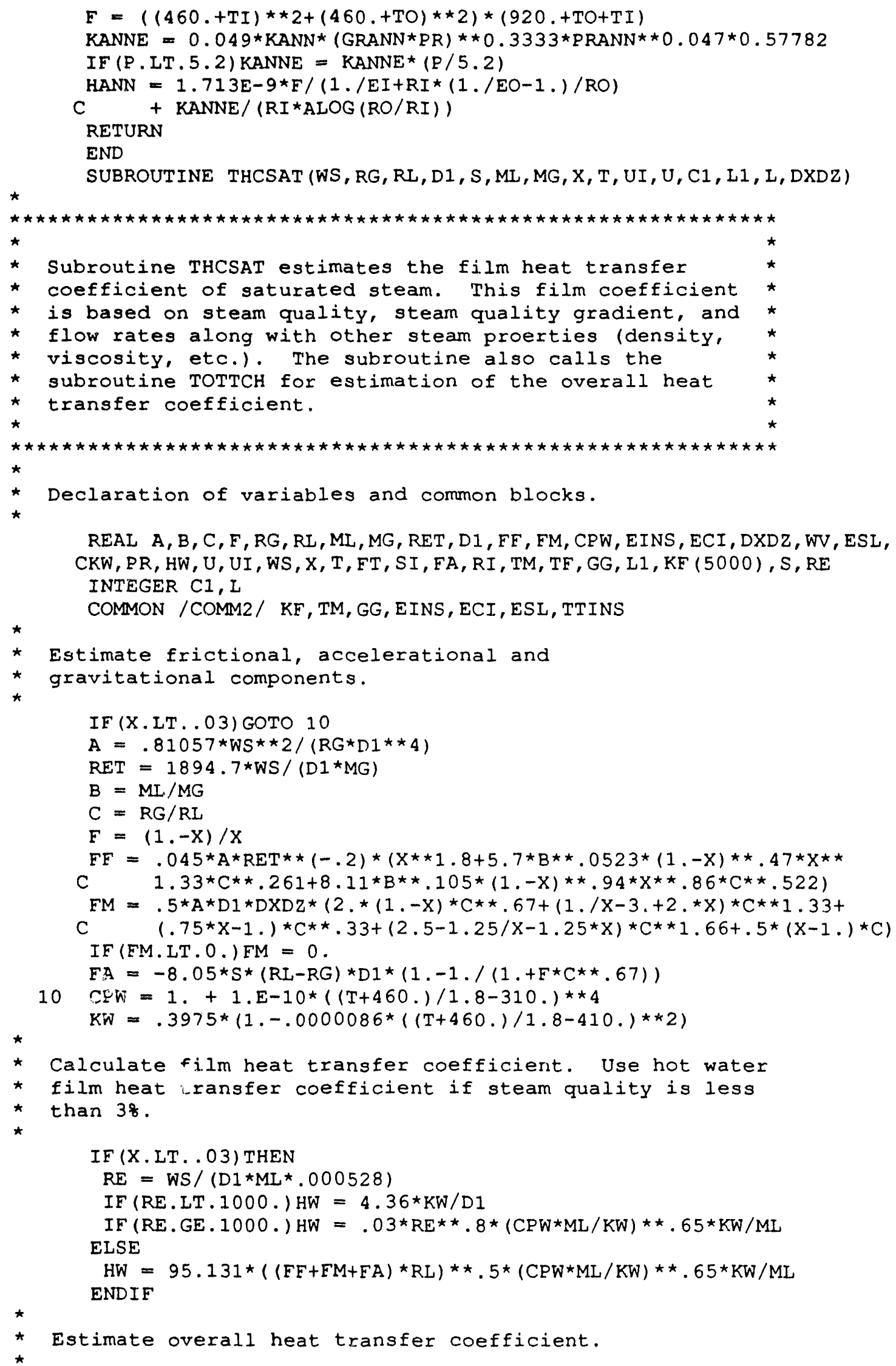


$R I=D 1 / 2$.

$U=U I+1 . /(H W \star R I)$

IF (L. NE. 1) THEN

$T F=T M+G G \star L 1$

CALL TOTTHC (UI, C1, TF, T, U)

ENDIF

RETURN

END 


\section{APPENDIX C}

Materials Description 


\section{MATERIALS DESCRIPTION}

\section{Pipe Dimensions}

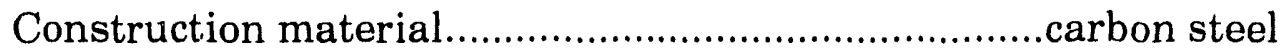

Inside diameter of inner pipe.....................................2.2.992 inches

Outside pipe of inner pipe............................................500 inches

Inside diameter of outer pipe.....................................4.950 inches

Outside diameter of outer pipe...................................5.500 inches

Insulation thickness (when used).................................450 inches

Pipe test section length..............................................36.00 inches

Coupling test section length......................................6.75 inches

Total test section length (pipe and coupling)...............42.75 inches

\section{Heat Transfer Properties}

Convective heat transfer coefficient........................... $0.8806 \mathrm{Btu} / \mathrm{hr}-\mathrm{ft}^{2}{ }^{\circ} \mathrm{F}$

Emissivity of carbon steel 0.60

Insulation, thermal conductivity

Air, thermal ennductivity

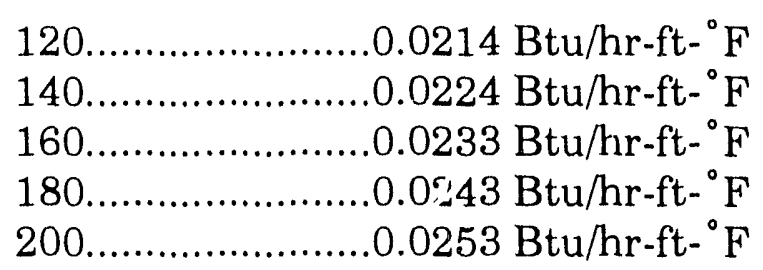

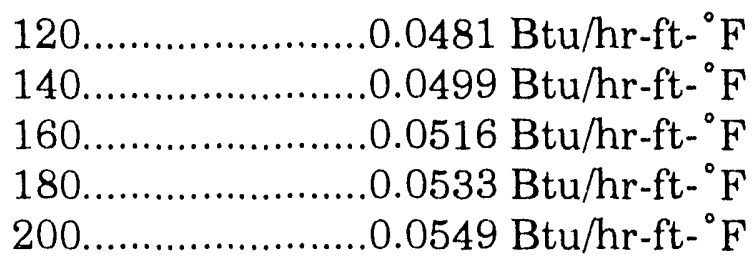



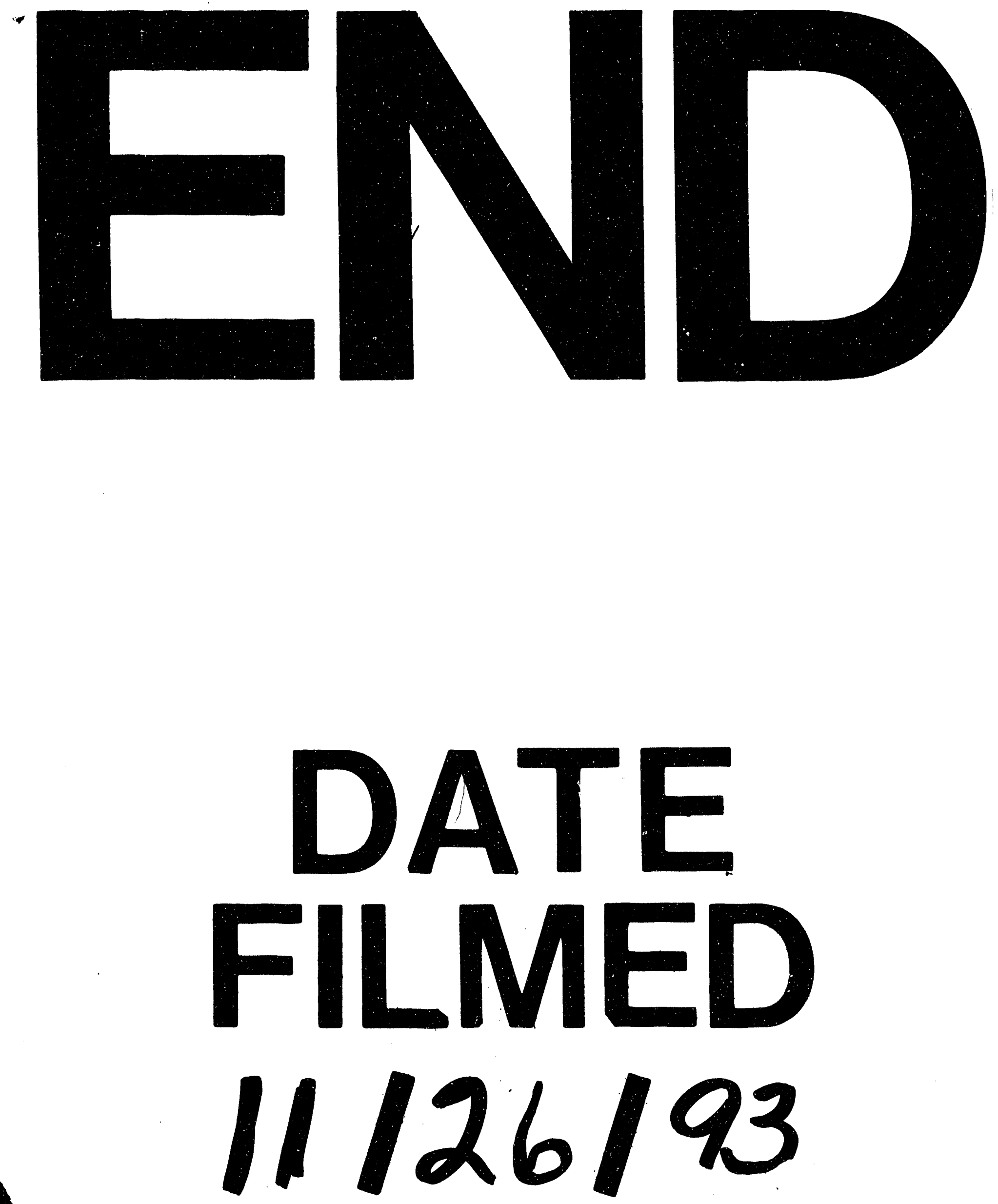
